\title{
ДВІ ПЕКТОРАЛІ - ШЕДЕВР ТА ЙОГО РЕПЛІКА
}

Pеферат: У статті на основі аналізу конструкиії, стилістики, семантики, функиіонального призначення пекторалей з Товстої Могили та Великої Близниці обтрунтовується висновок про виготовлення прикрас двома торевтами, які прачювали в різних майстернях.

Ключові слова: пектораль, Товста Могила, Велика Близниия, скіфи, торевтика, Діоніс, елевсінські культи.

Вступ. Дефініція пекторалі з Товстої Могили як шедевра греко-скіфської торевтики давно стала традиційним і загальновживаним формулюванням. Пектораль унікальна в своєму виконанні, але задумана і створена в певному культурному середовищі й не могла бути від нього повністю ізольованою. Серед інших виробів давньогрецьких торевтів цього часу, пектораль 3 Товстої Могили найчастіше зіставлялася 3 двома предметами - срібною амфорою з Чортомлика і ще однією пектораллю, що виявлена в кургані Велика Близниця в 1868 році (розкопки В.Г. Тізенгаузена). Але, якщо порівняння 3 амфорою грунтується на більш глибокому аналізі композиції та сюжетів двох виробів, то схожість 3 таманською пектораллю здається очевидною вже при першому погляді (рис. 1: 1, 2). Близькість двох пекторалей була помічена практично в момент відкриття прикраси в Товстій Могилі ${ }^{1}$, декларована безліччю робіт, іноді в курйозному контексті ${ }^{2}$. Такому стану сприяли, 3 одного боку, відсутність у скіфському середовищі і його найближчому оточенні подібних прикрас, 3 іншого - збіг за цілою низкою ознак у конструкції, композиції, художньому оформленні та наявних образах і сюжетах. Водночас багатьма дослідниками відзначалась «більша грубість», менша «складність виконання і художня цінність», «витонченість» та «досконалість техніки» пекторалі 3 Великої Близниці [Мозолевский 1972, с. 293; Мачинский 1978, с. 145; Манцевич 1980, с. 109; Савостина 1999, с. 201; Русяєва 2008, с. 523; Schwarzmaier 1996, S. 127-129; Jacobson 1995, p. 119; Fornasier 1997, S. 123-126; Williams 1998, p. 102]. Подібна оцінка є справедливою відносно кожної деталі пекторалі - литих фігурок тварин, квітів, прикрашених напівовами бордюрів, сканних візерунків на обоймах, левових голівок наконечників, рубчастого дроту, що імітує зернь і заповнює жолобки джгутів. Виготовлення будь-якого з перелічених елементів вимагало певної майстерності, навичок, нарешті, таланту, що й зумовлювало більш високий або низький технічний i художній рівень готового виробу.

Попри часті зіставлення обох пекторалей, до цього часу відсутнє їх системне i розгорнуте порівняння за основними напрямами вивчення, такими, як конструкція і техніка виготовлення, особливості стилістики та семантики образів і сюжетів прикрас. Навряд чи подібна задача може бути вирішена в межах однієї статті, тому акцентуємо увагу лише на найпомітніших нюансах цього кола проблем.

${ }^{1}$ Твердження Н.О. Гаврилюк про те, що А.П. Манцевич «впервые отметила общее и особенное пекторали из Толстой Могилы и пекторали из кургана Большая Близница» [Гаврилюк 2016, с. 284] не зовсім точне. Дійсно, А.П. Манцевич однією 3 перших відвідала розкопки Товстої Могили після відкриття пекторалі. До Орджонікідзе (від квітня 2016 року - м. Покров) вона прибула вже вранці 25 червня і оглянула місце знахідки безпосередньо в дромосі, а вже в 1974 році опублікувала статтю, в якій зіставила обидві прикраси [Манцевич 1974]. Але в наукових публікаціях пріоритет порівняння двох пекторалей належить Б.М. Мозолевському, який вказав на їх близькість двома роками раніше [Мозолевский 1972, с. 293]. Насправді ж ці прикраси першим порівняв С.В. Черненко. За спогадами С.М. Ляшко, яка перебувала на момент знахідки пекторалі в центральній могилі, Є.В. Черненко, назвавши прикрасу пектораллю, відразу же «привів аналогію 3 таманською знахідкою» (з листа С.М. Ляшко Ю.Б. Полідовичу).

${ }^{2}$ Так, у відомій книзі Л.Д. Кучми пектораль з Товстої Могили ідентифікована як прикраса «3 кургану Велика Близниця на Таманському півострові» [Кучма 2003, цв. фото после с.160]. 

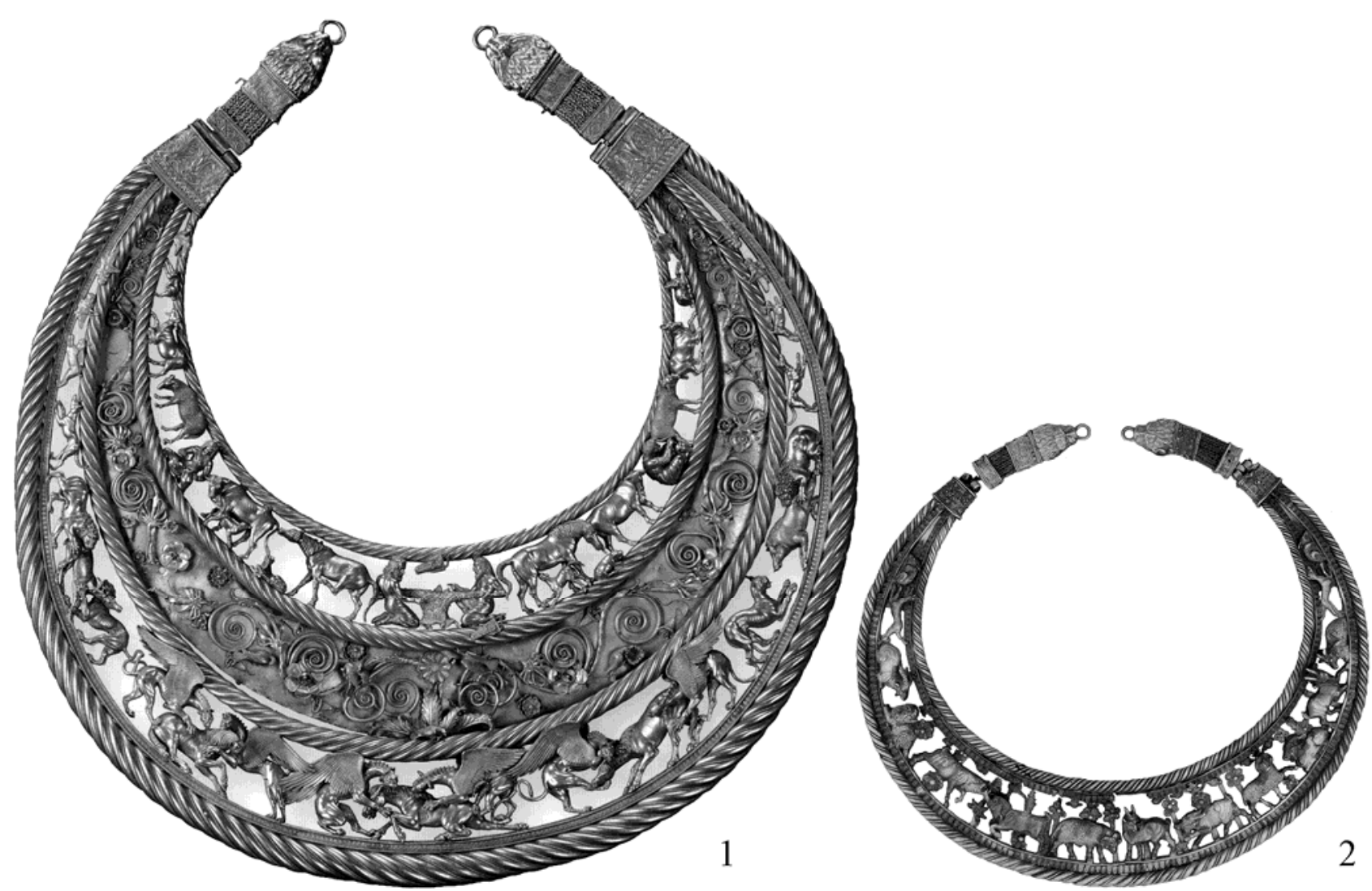

Рис. 1. Дві пекторалі: 1 - Товста Могила [Dally 2008, Abb. 2]; 2 - Велика Близниця [Piotrovsky and etc. 1986, pl. 255]

Fig. 1. Two pectorals: 1 - Tovsta Mohyla; 2 - Velyka Blyznytsia

Конструкція і техніка виготовлення. Навіть побіжний погляд на обидві прикраси відразу ж зазначає тотожність їх форми у вигляді півмісяця і загальної структури композиції, що складається 3 ажурного фігурного фризу, обрамленого крученими / псевдокрученими джгутами, заповненими по спіральним жолобкам рубчастим дротом. Збігається набір окремих персонажів (насамперед, отарних тварин - виключно рідкісних для виробів грекоскіфської торевтики) і сюжетів (гонитва зайця собакою). Однакова конструкція обойм, що охоплюють джгути, і приєднаних до них на трьохтрубчастих шарнірах застібок у вигляді пласких плетінок, заправлених по обидва боки в обойми, що закінчуються левовими головками $з$ кільцем у пащі (рис. 1: 1, 2).

Обидві пекторалі змонтовані з багатьох окремих деталей. При виготовленні тих чи інших деталей пекторалі з Товстої Могили та їх подальшого монтажу було використано кілька десятків різних технічних операцій ${ }^{3}$. Поза сумнівом, значна їх частина була також застосована і майстром пекторалі з Великої Близниці. Хоча кожна деталь цієї прикраси i якість їх монтажу наочно демонструють більш низький рівень його майстерності.

Поміж інших конструкторських рішень особливо примітне кріплення застібок пекторалей на рухомих шарнірних петлях, що $є$ явною інновацією для виробів грекоскіфської торевтики та ще більш наочно демонструє зв'язок обох прикрас. Подібний тип кріплення був відомий в ювелірній справі задовго до виготовлення пекторалей ${ }^{4}$, але практично не використовувався давньогрецькими торевтами, продукція яких була

\footnotetext{
${ }^{3}$ Найбільш повний перелік див. [Черняков, Підвисоцька 1999, с. 77, 78].

${ }^{4} \mathrm{~B}$ якості найбільш ранніх зразків подібного кріплення ювелірних прикрас Е. Якобсон наводить давньоєгипетські браслети і пекторалі з гробниць широкого хронологічного діапазону - від Тутанхамона (1336-1327 рр. до н.е.) до Шешонки II (890 р. до н.е.) [Jacobson 1995, p. 103, 104].
} 
орієнтована на споживачів зі скіфської знаті. На думку Е. Якобсон, саме вирішення проблеми генезису шарнірного кріплення пекторалей з Північного Причорномор'я здатне дати ключ до розуміння їх походження [Jacobson 1995, p. 103, 104] ${ }^{5}$.

Порівняння шарнірних з'єднань обох пекторалей найбільш виразно демонструє різний рівень майстерності двох торевтів. Простота конструкції шарнірних петель, що складаються 3 трьох циліндричних трубочок, припаяних до обойм основного корпусу і застібок та з'єднаних стрижнем з розклепаними кінцями, не вимагала не тільки великого художнього хисту, а й якоїсь більш-менш значної вправності ремісника. Подібна задача була під силу навіть ювеліру-початківцю. Тим більше показова недбалість, 3 якою виконані ці деталі на пекторалі з Великої Близниці, навіть беручи до уваги прижиттєві пошкодження прикраси. Загальна довжина петель краще збереженого шарніру лівого боку (для носія) менша ширини зовнішнього краю обойми. Циліндри петель різного розміру і конфігурації та погано підігнані одне до одного, внаслідок чого в місці шарнірного з'єднання утворені добре помітні шпарини (рис. 2: 3, 4).
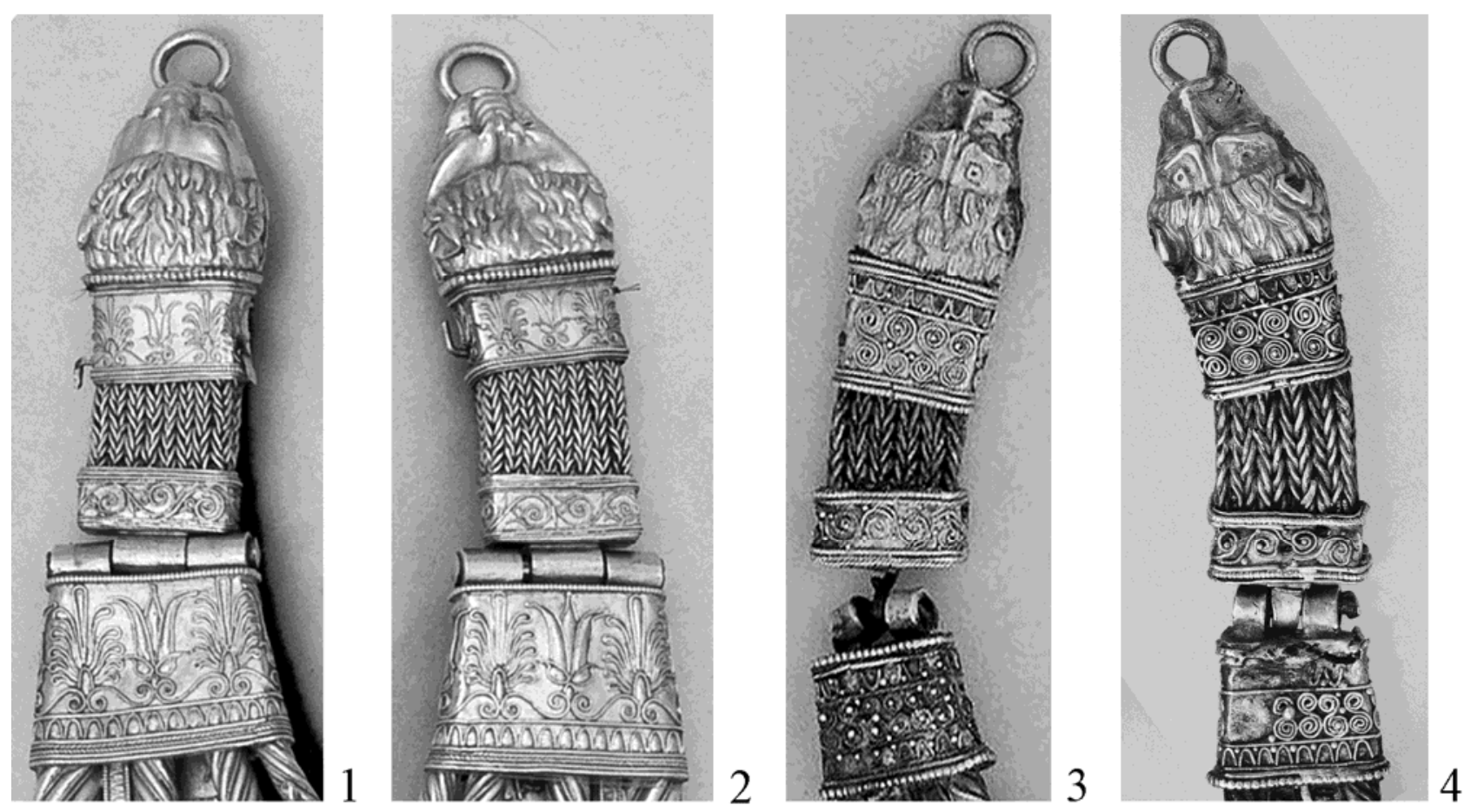

Рис. 2. Застібки пекторалей на шарнірному з'єднані:

$\mathbf{1 , 2}$ - Товста Могила; 3, 4 - Велика Близниця [Бабенко 2017а, рис. 2, 1-4]

Fig. 2. Hinged pectorals fasteners: 1, 2 - Tovsta Mohyla; 3, 4-Velyka Blyznytsia

Враження несумісності справляють і застібки пекторалі 3 Великої Близниці. У пекторалі з Товстої Могили ширина застібок вужча за ширину торцевої частині обойми основного корпусу, що гармонійно вписується в місяцеподібний абрис пекторалі (рис. 2: 1, 2). У таманської пекторалі ширина торця обойми основного корпусу вужча ширини обойми застібки. Це порушує плавність загального абрису прикраси і справляє враження певної чужорідності застібок у конструкції пекторалі в цілому (рис. 2: 3, 4). Виникає відчуття їх

${ }^{5}$ Постановка проблеми в подібному формулюванні здається не зовсім коректною. Вирішувати слід проблему генезису шарнірних петель саме пекторалі з Товстої Могили, від якої пектораль 3 Великої Близниці була вторинним виробом, включаючи і запозичення безпосередньо конструкції шарнірів. Цій проблемі присвячена спеціальна стаття, де обгрунтовується запозичення майстром пекторалі ідеї шарнірних петель 3 конструкції аттичних і халкідський шоломів [Бабенко 2017а, с. 3747]. 
вторинності, того, що ці деталі створювалися не спеціально під параметри цієї прикраси, а були пристосовані вже готові застібки іншого виробу ${ }^{6}$.

Але ще більш помітна відмінність двох пекторалей простежується в різних способах забезпечення жорсткості конструкції, а також у будові кручених / псевдокручених джгутів, що обрамляють фігурні фризи. Нерухомість основного корпусу пекторалі з Товстої Могили, що складається з чотирьох джгутів і численних фігурок $-20{ }^{7}$ в межах верхнього фризу і 23 нижнього, досягалася за рахунок точкового припаювання з проміжками в 20-22 мм до середніх джгутів пекторалі суцільної золотої пластини у формі півмісяця, що послуговувала своєрідним ребром жорсткості [Підвисоцька, Черняков 2002]. А також за допомогою припаювання до джгутів, що утворюють крайні фризи, протягом усієї їх довжини, верхніх і нижніх частин горельєфних фігурок. В останньому випадку успішному вирішенню завдання сприяла відповідність розміру фігурок і висоти отвору між джгутами. Посередині, в ширшому місці, були припаяні найвищі фігури. I далі, зі звуженням фризу до кінців, зменшувався і розмір фігурок, точно вписаних в висоту проміжку між верхнім і нижнім джгутом.

Перед майстром пекторалі з Великої Близниці, на перший погляд, стояло простіше завдання щодо забезпечення жорсткості конструкції виробу - потрібно було досягти нерухомості не чотирьох джгутів і трьох образотворчих фризів, а всього лише двох джгутів $і$ одного фризу, утвореного 15 фігурками тварин. Однак для вирішення цієї задачі майстром був обраний інший шлях. Якщо на пекторалі з Товстої Могили жорсткість ажурних фризів забезпечують співмірні висоті проміжку фігурки, то використання цього ж прийому в конструкції пекторалі 3 Великої Близниці, за умови дотримання пропорційності репрезентованих тварин - баранів і цапів - неможливе. На думку Ю.П. Калашника, «благодаря мастерски продуманной композиции фигуры козлов и баранов, изображенных в естественных позах, не стеснены рамками фриза» [Калашник 2014, с. 189]. Але у цьому випадку для забезпечення жорсткості пекторалі знадобилося створення досить громіздкої конструкції у вигляді двох бордюрів 3 Г-подібним профілем, припаяних до джгутів пекторалі. До внутрішнього боку бордюрів були припаяні 17 золотих смужок (рис. 3: б). Ці ж смужки використані і для кріплення більшості фігурок тварин, 4-, 6- і 8-пелюсткових розеток, листя і коробочок маку, якими частково схований неестетичний вигляд самих смужок. I тільки крайні по обидва боки фризу фігурки лежачих цапів припаяні безпосередньо до бордюрів (рис. 3: 3, б). Забезпечити жорсткість конструкції по краям пекторалі могли і фігурки собак та зайців. Однак і тут художник віддав перевагу іншому шляху, припаявши до бордюрів у кутках фризу трикутні пластини, чим помітно послабив загальне враження ажурності прикраси в цілому (рис. 3: 4).

Велика кількість і розмаїття деталей (2 бордюри, 17 вертикальних смужок, 2 трикутні пластини) для забезпечення жорсткості одноярусної пекторалі може здатися невиправдано надлишковою. Однак перебільшена заклопотаність майстра проблемою зміцнення конструкції пекторалі знаходить пояснення, якщо звернути увагу на деякі особливості будови іiі джгутів. У пекторалі 3 Товстої Могили чотири псевдокручені джгута репрезентовані монолітними порожнистими трубками (спаяними 3 двох частин кожна), що полегшувало досягнення жорсткості конструкції виробу в цілому. Але у джгутів пекторалі 3 Великої Близниці інша будова ${ }^{8}$. Кожен 3 джгутів був скручений 3 трьох ${ }^{9}$ окремих дротів або

${ }^{6}$ Подібне відчуття посилює знахідка в іншому похованні Великої Близниці - склепі № 1 намиста зі схожими наконечниками у вигляді левових голівок 3 «додатковими очима» [Калашник 2014, с. 171].

${ }^{7}$ Не рахуючи наявні предмети - руно, горити і посуд.

${ }^{8}$ Візуально різниця була помічена А. Шварцмайєр, яка, порівнюючи джгути обох пекторалей, зазначила «більш тугіші нитки шнурів» прикраси з Великої Близниці [Schwarzmaier 1996, S. 129].

${ }^{9}$ Кількість трубочок, 3 яких скручені джгути пекторалі, легко визначити по їх фотографії. На нижньому джгуті, на невеликій ділянці з трьох витків (це помітно і з лицьового, і зі зворотного боку) 

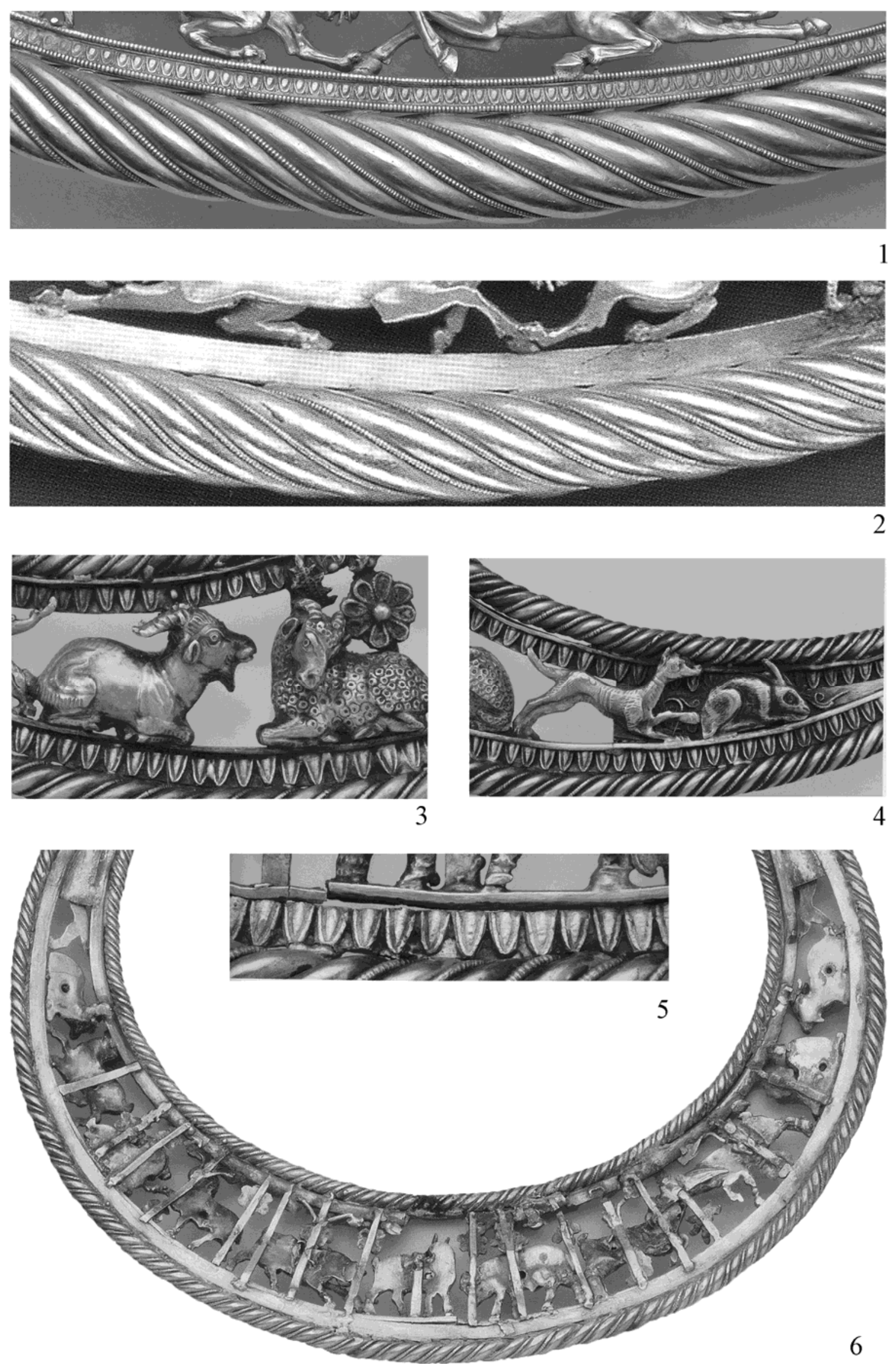

відсутній рубчастий дріт, що імітує зернь і заповнює поглиблення між трубочками. Це дозволяє визначити кількісний крок витка, i, відповідно, число трубок в джгуті, що дорівнює трьом. 
$\leftarrow$ Рис. 3. Фрагменти пекторалей з Товстої Могили (1 - лицьовий бік [Dally 2007, Abb. 2]; 2 зворотний бік [Scythian gold 1999, cat. 172]) та Великої Близниці (3-5 - лицьовий бік; 6- зворотний бік) [Калашник 2014, с. 191-193]

$\leftarrow$ Fig. 3. Fragments of the pectorals from the Tovsta Mohyla (1 - front side; 2 - flip side) and Velyka Blyznytsia (3-5 - front side; 6 - flip side)

трубочок ${ }^{10}$. Використання подібної техніки не дозволяло отримати такий же жорсткий джгут, як у випадку з цільними порожнистими трубками. Дійти такого висновку дозволяють спостереження над деякими прикрасами зі джгутами, звитими подібним чином.

У цій же техніці були виготовлені джгути двох браслетів з некрополя Пантікапея, у котрих розійшлися нещільно сплетені стрижні, утворивши в деяких місцях добре помітні просвіти [Калашник 2014, с. 104]. 3 шести порожнистих трубочок був звитий джгут гривни зі скіфами-вершниками на кінцях з Куль-Оби [Древности Боспора Киммерийского 1854, с. 58; Петренко 1978, с. 46; Уильямс, Огден 1995, с. 137]. На відміну від браслетів 3 пантікапейського некрополя, майстру, який виготовив гривну, вдалося досягти більш якісного, тугого скручування трубочок, які щільно прилягають одна до одної, зовсім не утворюючи просвітів. Ймовірно, подібна конструкція джгута визначила i своєрідну «рухливість», «гнучкість», «пружність» гривни з Куль-Оби ${ }^{11}$. Параметри прикраси можуть змінюватися в залежності від іiі положення, i, як результат, форма гривни може бути в одних випадках трохи витягнута по горизонталі, в інших - по вертикалі, або ж мати округлий абрис, що помітно на фотографіях прикраси в різних виданнях [Бабенко 2019, с. 497, 498, рис. 6]. Це властивість гривни знайшла віддзеркалення в досить широкій варіативності ії параметрів, наведених різними дослідниками: $34 \times 26 \mathrm{~cm}$ [Петренко 1978, с. 46], діаметр $25,8 \mathrm{~cm}$ [Piotrovsky and etc. 1986, pl. 126; Jacobson 1995, p. 120], близько 25 см [Schiltz 1994, S. 162], 26,6 × 24 см [Уильямс, Огден 1995, с. 137], довжина 31,5 см [Алексеев 2012, с. 184].

Джгути пекторалі з Великої Близниці виготовлені в такій же техніці і також могли мати схожу рухливість. Це і вимагало від майстра додаткових зусиль для досягнення необхідної жорсткості не тільки загальної конструкції, але ще й самих джгутів. Відповідно, і схожі зовні бордюри обох пекторалей могли виконувати в конструкції прикрас різні функції. Бордюр нижнього фриза пекторалі з Товстої Могили, зменшуючи висоту просвіту, забезпечував оптимальне розміщення скульптурних фігур між двома джгутами фриза. А також візуально збільшував ширину фриза, створюючи більш гармонійне співвідношення розмірів верхнього і нижнього фризів. Два бордюри пекторалі з Великої Близниці, в поєднанні з сімнадцятьма поперечними смужками, були каркасом для кріплення фігур фриза i забезпечували нерухомість скручених з трьох трубочок джгутів пекторалі (рис. 3: 1-б). Такі різні підходи при створенні базових елементів у конструкції обох пекторалей свідчать про те, що,

${ }^{10}$ Техніка виготовлення цих джгутів спеціально не розглядалася, але кілька дослідників в гранично лаконічній формі охарактеризували їх конструкцію, дійшовши абсолютно діаметральних висновків. Б. М. Мозолевський побачив в них дві порожнисті джгутоподібні трубки [Мозолевський 1979, с. 213]. М.Ю. Трейстер визначив їх як «ложновитые трубки с бронзовым сердечником» [Трейстер 2010, с. 555]. На думку Ю.П. Калашника, лунниця пекторалі була утворена «двумя жгутами из перевитых проволок» [Калашник 2014, с. 189]. Найбільшої довіри заслуговує останнє визначення, зроблене дослідником, найближче знайомим з прикрасою. Цілковито чітке враження про конструкцію джгутів саме 3 перевитих «дротів» або трубок справляють і фотографії прикраси. Особливо добре це помітно в місцях відсутності рубчастого дроту, що імітує зернь і заповнює спіральні жолобки джгута. Подібну конструкцію джгутів - 3 перекручених дротів підтвердила і науковий співробітник Відділу античного світу Державного Ермітажу О.В. Катцова, оглянувши пектораль на моє прохання, і якій я висловлюю щиру вдячність.

${ }^{11}$ Про цю властивість гривни 3 Куль-Оби мені повідомили завідувач Відділом археології Східної Європи та Сибіру Державного Ермітажу А.Ю. Алексєєв і науковий співробітник Відділу античного світу Державного Ермітажу О.В. Катцова, яким я вдячний за увагу до моїх прохань. Про конструкцію гривни з Куль-Оби див.: [Бабенко 2018, с. 30-47]. 
незважаючи на загальну зовнішню схожість, ці прикраси відрізняє не тільки більший або менший рівень майстерності торевтів, які виготовили їх, а й застосування ними різних конструктивних рішень i технологій виготовлення окремих деталей [Бабенко 2018а]. Найімовірніше, майстер пекторалі з Великої Близниці не тільки не володів технологією виготовлення порожнистих псевдокручених трубок, але й не усвідомлював необхідність їх використання в конструкції подібної прикраси.

Стилістика. Загальна структура композиції обох прикрас, попри зазначену вище схожість форми і окремих елементів, виявляє і такі ж разючі відмінності. 3 усіх відомих предметів греко-скіфської торевтики пектораль 3 Товстої Могили $є$ виробом 3 найбільш виразною вертикальною і горизонтальною структурою композиції, що було відзначено багатьма дослідниками. Тернарна вертикальна структура пекторалі вирізняється різким протиставленням образів (дикі і фантастичні тварини - люди і худоба) і сюжетів (ідеї смерті - ідеї народження/ годування) нижнього і верхнього фризів. Горизонтальна структура характеризується умовною симетрією лівого і правого боку, причому на верхньому фризі зміст багатьох образів і сюжетів лівого боку протилежний правому (наявність і відсутність налобної пов'язки; підвішений або лежачий горит; лошата і телята - тільки що народжені чи вже смокчуть вим'я тощо). Наявність на пекторалі з Великої Близниці всього одного фризу від самого початку зумовлює відсутність вираженої вертикалі в іiі композиції. Але i горизонтальній композиції властива набагато менш виражена симетрія - мабуть, тільки сцени переслідування зайця собакою на кінцях фризу відповідають цій вимозі. Решта тварин - цапи i барани - утворюють п'ять груп (центральна група з цапом і зверненими до нього бараном i ще одним цапом, а також чотири парні - по дві з кожного боку - групи тварин різного виду), які демонструють хіба що кількісну симетрію. I склад протиставлених тварин, і утворені ними сюжети, не симетричні, а саме «не обмежені» [Калашник 2014, с. 189] в позах будьякими умовностями.

При всій унікальності пекторалі з Товстої Могили, іiі характерною особливістю $є$ використання в композиції значної кількості ідей, запозичених майстром з різних творів художньої культури Давньої Греції і Фракії. Ще Б.М. Мозолевським була помічена залежність структури композиції пекторалі від скульптурних фронтонів Парфенону, котра реалізувалася в наслідуванні підтрикутної форми образотворчого поля з високим центром, що зменшувався до країв; в побудові центру у вигляді парної скульптурної композиції 3 «полегшеним» центром; в протиставленні верхнього i нижнього фризів пекторалі, аналогічного яскраво вираженому контрасту змісту композицій східного i західного фронтонів Парфенону (рис. 4: 2, 3) [Мозолевський 1979, с. 216, 217]. Побачити в композиції пекторалі з Великої Близниці будь-яку близькість до фронтонів Парфенону важко. У центрі фриза домінує фігурка цапа. Образотворче поле, незважаючи на місяцеподібний абрис, на більшій частині своєї протяжності за рахунок пропорційних фігурок тварин, рівномірне. Відсутні і будь-які ідеї протиставлення.

Одним із джерел натхнення для майстра пекторалі з Товстої Могили могли бути пекторалі з Фракії і Македонії [Treister 2005, p. 63], що також виявляють подібність за цілою низкою ознак - широким місяцеподібним абрисом, структурою композиції у вигляді концентричних образотворчих фризів, використанням в орнаментації витких рослинних пагонів зі спіральними завитками (рис. 4: 4, 5). Однак враження схожості повністю зникає при порівнянні балканських пекторалей з таманською і навряд чи теза про їх можливу спорідненість коли-небудь з'явилася, якби не була знайдена пектораль 3 Товстої Могили. Абрис пекторалі з Великої Близниці помітно вужче. Відсутня характерна концентричність фризів.

На аналізі рослинних композицій двох пекторалей варто зупинитися докладніше. На прикрасі з Товстої Могили рослинним орнаментом, що складається 3 центрального куща аканта і пагонів зі спіральними завитками, а також квітів (розеток різних типів і дзвіночків) $\mathrm{i}$ 

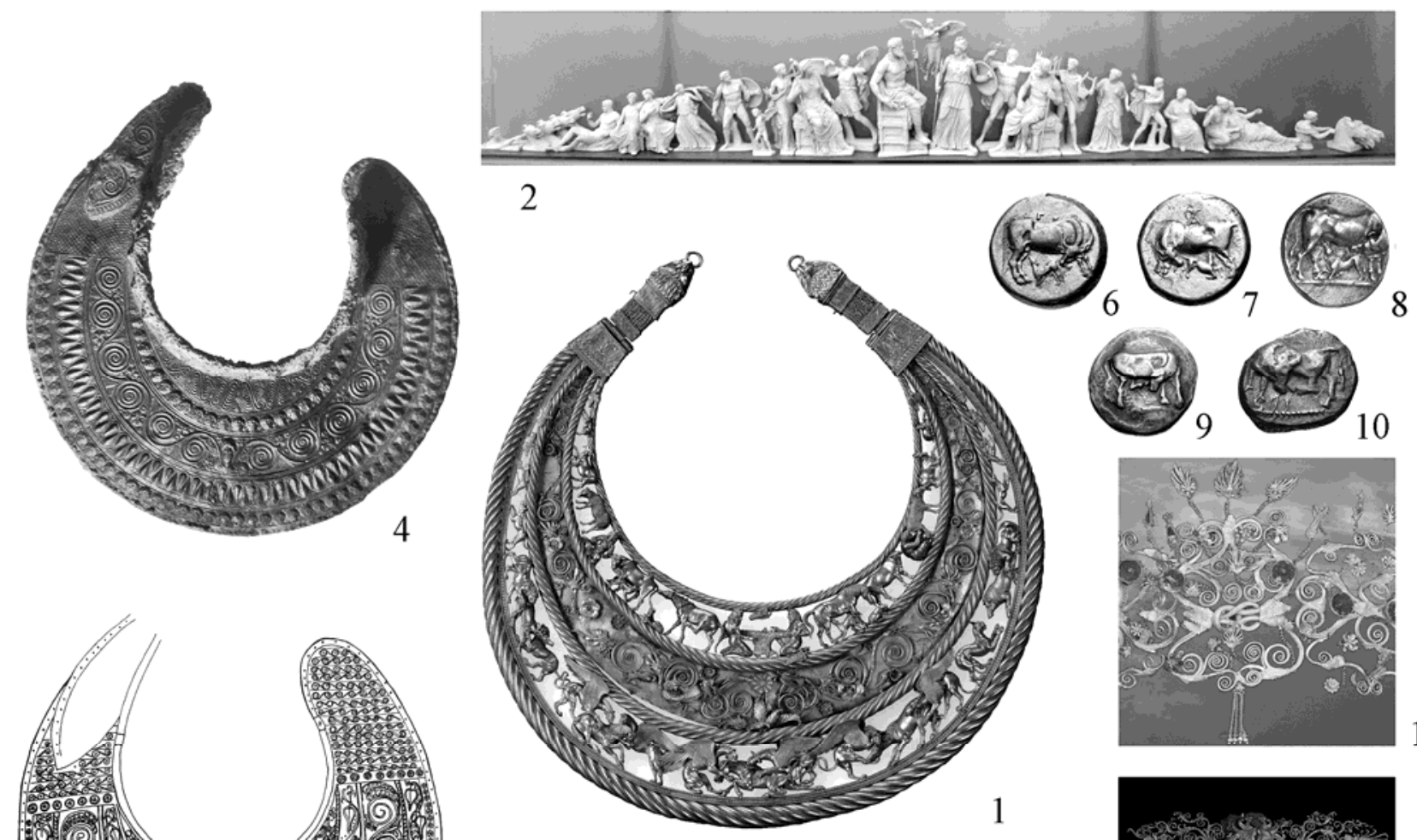

4
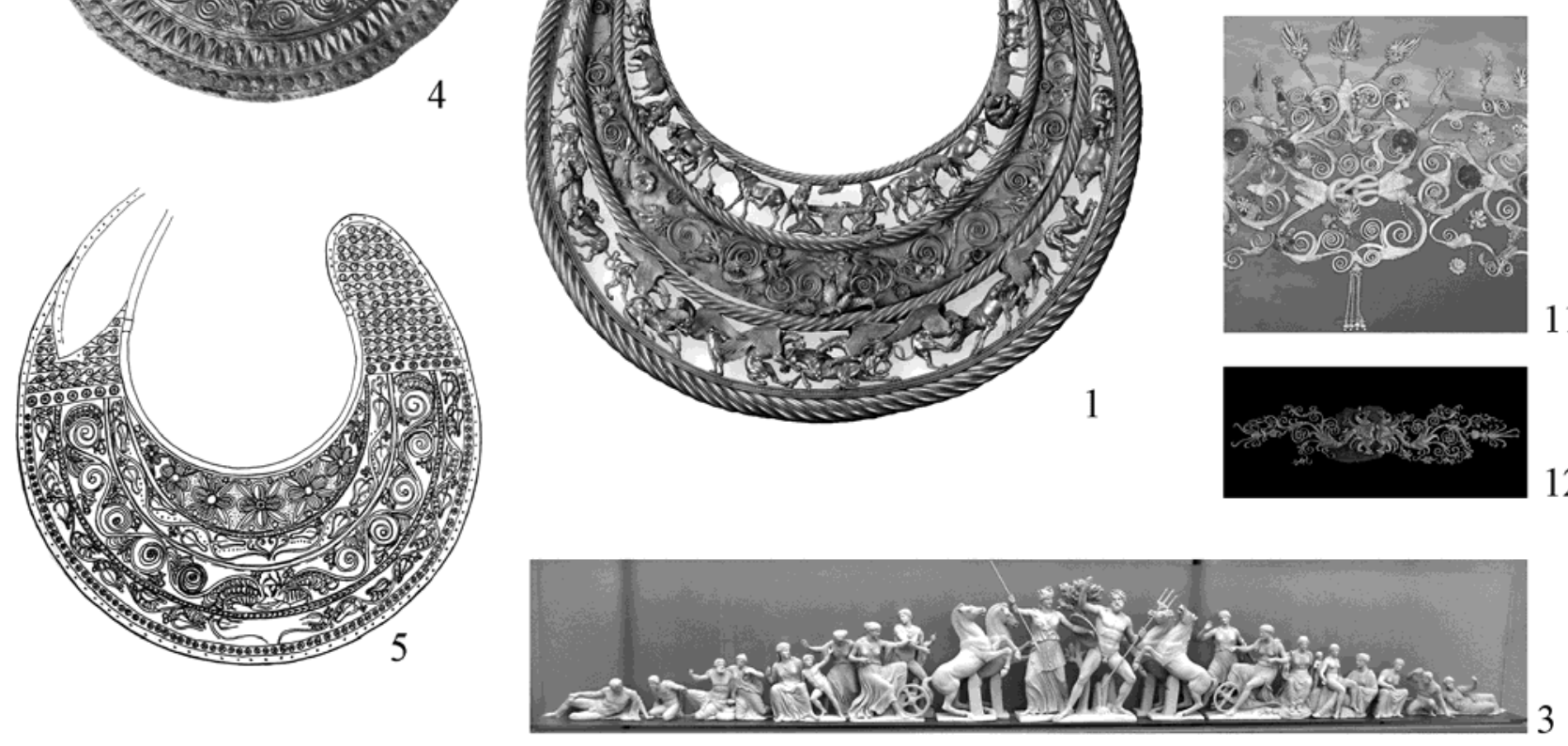

Рис. 4. Можливі запозичення в композиції, сюжетах і образах пекторалі з Товстої Могили: 1 пектораль $з$ Товстої Могили [Dally 2008, Abb. 2]; 2, 3- скульптурні групи фронтонів Парфенона (реконструкція) [http://ermakvagus.com/Europe/Greece/Athens/parthenon-rus.html]; 4 - пектораль 3 Мезека [Венедиков, Герасимов 1973, ил. 230]; 5 - пектораль з Вирбиці [Archibald 1985, fig. 2]; 6-10 монети із зображенням сцен годування теляти коровою (6 - Діррахія; 7 - Аполлонія; 8 - Карістос) і корови 3 піднятою задньою ногою (9, 10 - Еретрія) [Бабенко 2017, рис. 3, 4, 5, 8-10]; 11 - діадема 3 Вергіни, фрагмент [Andronicos 1984, p. 196]; 12- діадема 3 Ставруполіса [https://www.amth.gr/en/exhibitions/permanent-exhibitions/gold-macedon]

Fig. 4. Possible borrowings in the composition, plots and images of the pectoral from the Tovsta Mohyla: 1-pectoral from the Tovsta Mohyla; 2, 3- sculptural group of pediments of the Parthenon (reconstruction); 4-pectoral from Mezek; 5- pectoral from Varbitsa; 6-10 - coins depicting scenes of feeding a cow calf (6 - Dyrrhachion; 7 - Apollonia; 8 - Karystos) and cow with raised hind leg (9, 10 Eretria); 11 - diadem from Vergina, fragment; 12 - diadem from Stavroupoli

пальметок, прикрашений середній фриз ${ }^{12}$. Унікальність цього фриза пекторалі зумовлена, перш за все, його технічним виконанням. В цілому ж, на предметах торевтики в IV ст. до н.е. різні варіанти подібних рослинних композицій використовувалися досить широко. Якщо говорити саме про композицію з яскраво вираженим центром, від якого в'ються пагони, то краще за все вона репрезентована на пластинах парадних головних уборів ${ }^{13}$. Ця схема була

12 Детальний опис середнього фризу див. [Мозолевський 1979, с. 83-86; Підвисоцька, Черняков 2002, с. 17-26; Pfrommer 1982, S. 156-159; Gebauer 1997, S. 147-160] та ін.

${ }^{13}$ Пластини 3 подібним декором входили до складу всіх парадних уборів Чортомлика [Алексеев и др. 1991, кат. 113, 122, 128, 136], а також Товстої Могили [Мозолевський 1979, рис. 110], курганів № 8 групи «П'ять братів» Слизаветівського могильника [Скрыпник 1999, фото 1], №№ 2 (погр. 2 ) і 22 
реалізована і в декорі гюнівської пластини, а також на нижній частині тулуба чортомлицької амфори. При цьому, в рослинну композицію на амфорі і на більшості пластин, як і на пекторалі, у якості неодмінних персонажів включені птахи. Поява таких композицій в грекоскіфському мистецтві, поза сумнівом, пов'язана із зовнішнім імпульсом, а саме із фракійського, македонського і південноіталійського регіонів, де подібні рослинні композиції використовувалися для декору різних предметів мистецтва [Pfrommer 1982, S. 119-190; Gebauer 1997, S. 147-160]. Значне поширення цієї схеми рослинної композиції на різноманітних виробах греко-скіфської торевтики не дозволяє стверджувати виключно зовнішній характер іï запозичення при виготовленні майстром середнього фриза пекторалі, який міг «підглянути» подібний орнаментом на інших виробах. Набагато виразніше про це свідчить близькість технічного втілення такого орнаменту із закручених у спіраль дротяних вусиків, листків аканту з рубчастими краями, полум'яніючих пальмет, подвійних розеток, якими утворені об'ємні композиції середнього фризу пекторалі і дротяних діадем з гробниці Філіпа II в Вергіні і Ставруполіса (рис. 4: 11, 12) [Gebauer 1997, S. 149].

На пекторалі з Великої Близниці звивистими рослинними візерунками, виконаними в техніці філіграні, прикрашені трикутні кутові пластини. Прикриті фігурками собаки і зайця, вони ледь помітні на загальному тлі. Більше впадають в очі квіти основного образотворчого поля. У порівнянні зі середнім фризом пекторалі з Товстої Могили, квіти таманської пекторалі поступаються і художнім рівнем, і номенклатурою репрезентованих видів. Вони не утворюють rankenornament, а розташовуючись у верхній або нижній частині образотворчого фризу, слугують своєрідним маскуванням для «невиразних» стовпчиків. Флора пекторалі репрезентована 4-, 6- і 8-пелюстковими розетками 3 округлими пелюстками, 8-пелюстковою квіткою з гострими пелюстками, а також гострозубчастим листям і кулястими коробочками 3 вертикальними реберчастими перегородками і сегментованим диском. Вже Л.Е. Стефані вони були атрибутовані як коробочки маку (а розетки - як макові квітки) [Стефани 1871, с. 18]. У наступних роботах це визначення набуло підтримки [Толстой, Кондаков 1889, с. 59; Шауб 2004, c. 151; 2007, с. 126; Русяєва 2008, с. 523; Калашник 2014, с. 189] ${ }^{14}$. Предмети дійсно напрочуд правдоподібно нагадують макові коробочки. Але, 3 огляду на крайній схематизм інших рослинних елементів, в них можна побачити і спрощене зображення бутонів. Подібні бутони більш реалістичної версії представлені на підвісках сітчастих нагрудників (Солоха, Пісочин, Бердянський курган) [Манцевич 1987, кат. 38; Бабенко 2005, рис. 4: 15, фото 2; Мурзин и др. 2017, с. 110, кат. 100б] і на пластинах одного з головних уборів Чортомлика [Алексеев и др. 1991, кат. 128]. Морфологія гострозубчастого листя, з огляду на його схематизм, може цілком відповідати листю аканфа [Калашник 2014, с. 189], але його розташування на верхівках стовпчиків погано узгоджується з морфологією рослини. Якщо прийняти визначення «бутонів» як насіннєвих коробочок маку, то і листя, з огляду на велику ступінь подібності з природним прототипом, слід інтерпретувати як макове. Однак, як і в попередніх випадках, говорити про зовнішнє запозичення немає підстав - в IV ст. до н.е. подібні образи рослинного орнаменту використовувалися для декору різноманітних виробів греко-скіфської торевтики дуже широко.

Ідеї деяких сцен верхнього фризу пекторалі з Товстої Могили - сцени годування теляти коровою або «чухання» задньою ногою коня - могли бути запозичені торевтом з низки монетних сюжетів. Близькі за змістом сцени можна побачити на монетах Керкіри (Корфу), Аполлонії, Діррахії та Карістоса, а також Еретрії, які буквально або в творчо переробленому вигляді були відтворені торевтом на пекторалі (рис. 4: 6-10) [Бабенко 2017, с. 30-33]. На таманській пекторалі також присутня тварина (коза? вівця?), яка чухає вухо, але іiі вигляд близький не монетному сюжету, а скоріш репрезентує своєрідну алюзії на сцену пекторалі з Товстої Могили (рис. 8: 1).

(погр. 1) біля с. Вільна Україна [Leskov 1974, Abb. 88, 123, 124], № 8 Пісочинського могильника [Бабенко 2005, рис. 15: 1, фото 12], № 5 поблизу с. Оксютинці [Firsov, Žuravlev 2007, Abb. 17].

${ }^{14}$ Е. Якобсон визначила ї як «gourdshaped objects», тобто, «предмети в формі гарбуза» [Jacobson 1995, p. 118]. 

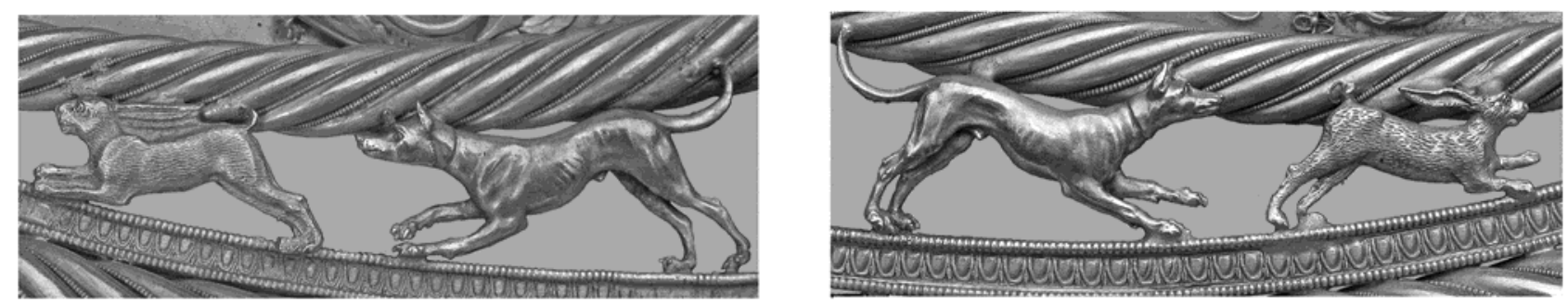

\section{1}
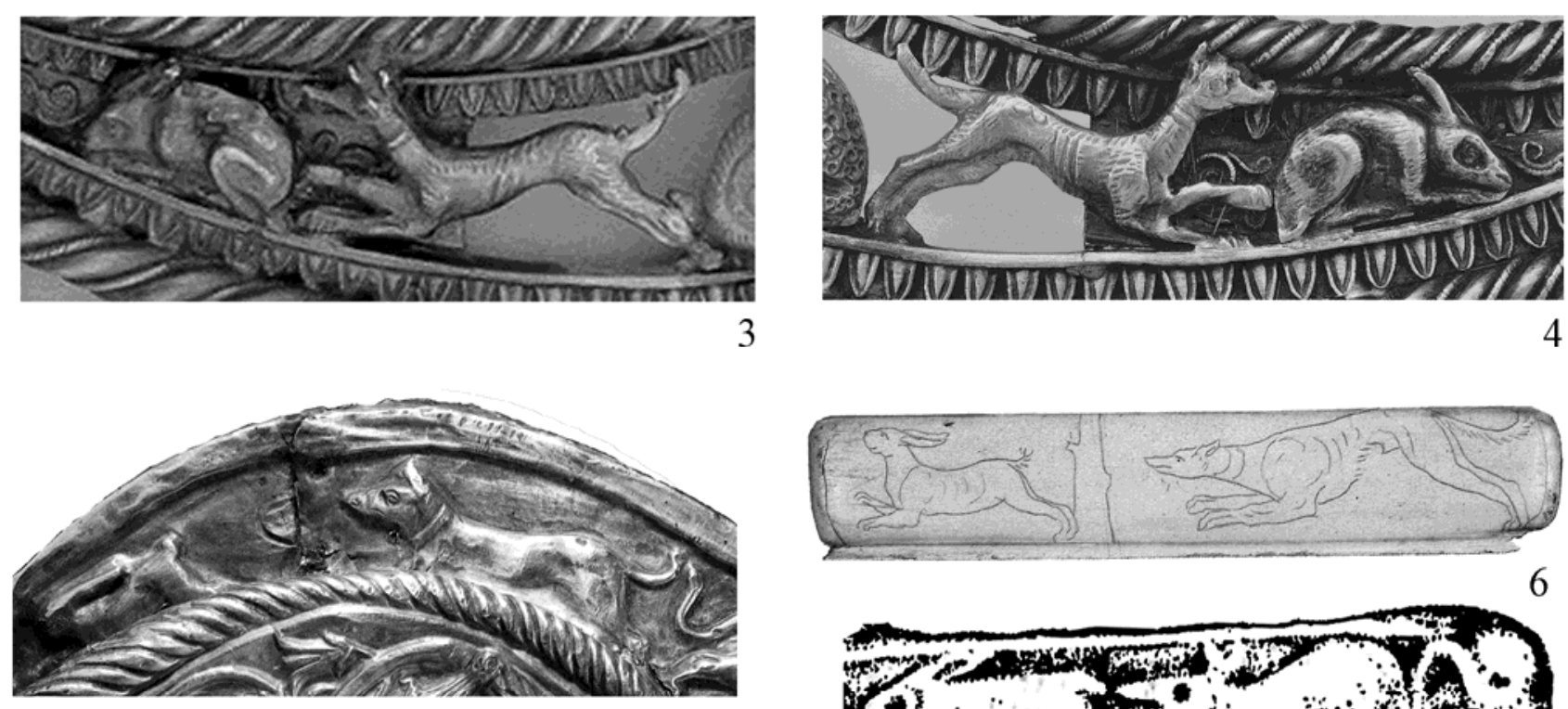

6
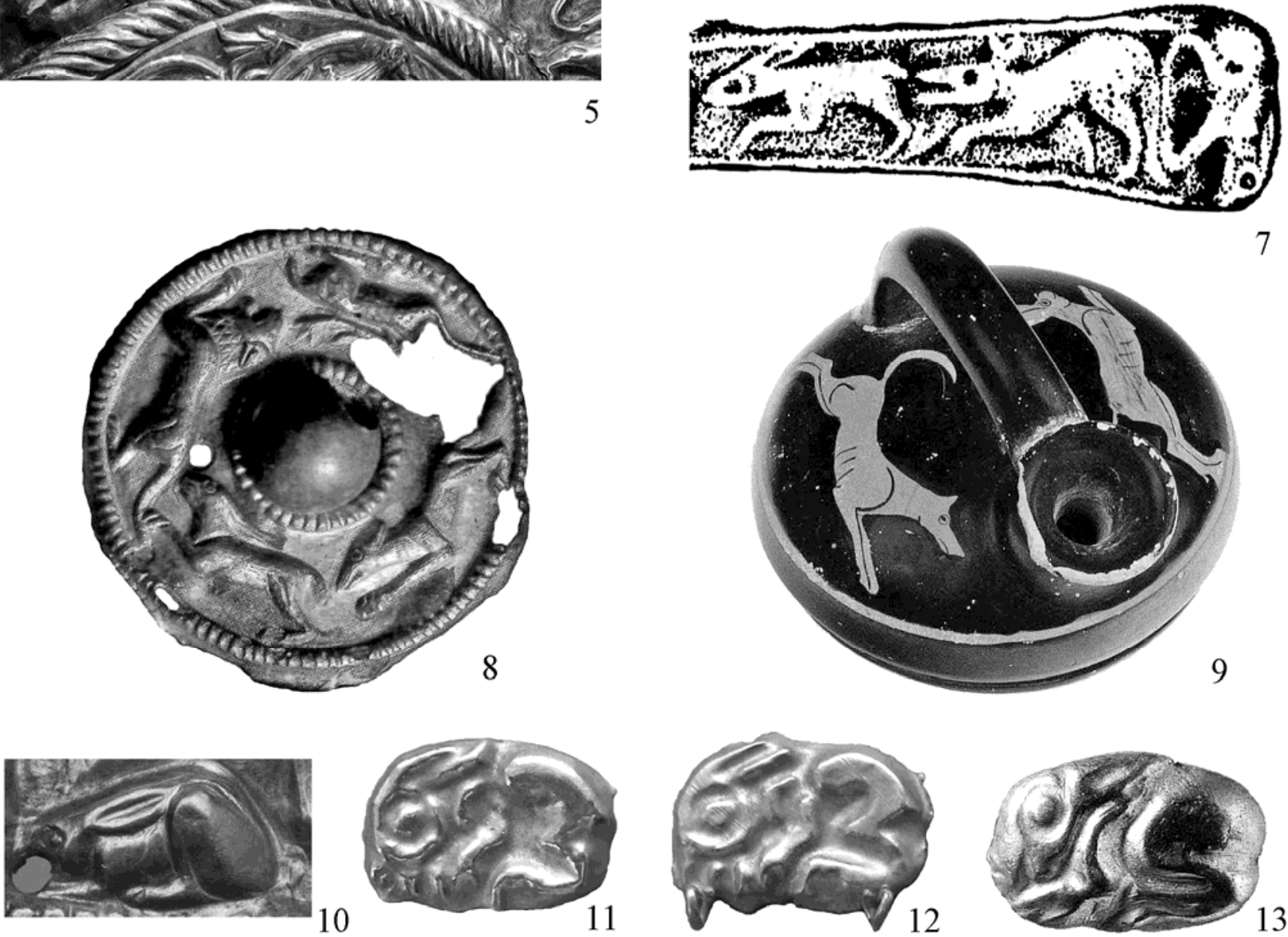

Рис. 5. Сцени переслідування зайця собакою (1-9): 1, 2 - пектораль 3 Товстої Могили, фрагмент [Dally 2008, Abb.2]; 3, 4 - пектораль з Великої Близниці, фрагмент [Калашник 2014, с. 188, 193]; 5 оббивка горита з Мелітопольського кургану, фрагмент [Scythian gold 1999, p. 226, cat. 172]; 6 - накладка кістяного гребеню з Куль-Оби, фрагмент [Piotrovsky and etc. 1986, pl. 255]; 7 - бляха з Салонта, фрагмент 
[Kemeczei, 2009, Taf. 59, 18]; 8 - бляха 3 Феттерсфельде (Віташково), фрагмент [Nawroth 2007, Abb. 3]; 9 аскос з Німфейського некрополю [Vickers 2002, pl. 8]. Зображення зіщуленого зайця (10-13): 10 - бляшка 3 Куль-Обы, фрагмент [Piotrovsky and etc. 1986, pl. 197]; 11, 12 - курган 2 Пісочинського могильника [Бабенко 2005, фото 3]; 13 - могила 1b Німфейського некрополя [Vickers 2002, pl. 5]

Fig. 5. Scenes with a dog chasing a hare (1-9): 1, 2 - pectoral from the Tovsta Mohyla, fragment; $\mathbf{3}$, 4 - pectoral from the Velyka Blyznytsia, fragment; 5 - overlay of a gorytos from the Melitopol barrow, fragment; 6 - bone overlay of a comb from the Kul-Oba barrow, fragment; 7 - plaque from Salonta, fragment; 8 - plaque from Vettersfelde (Witaszkowo), fragment; 9 - askos from Necropolis at Nymphaeum. Image of shrunken hare (10-13): 10 - plaque from the Kul-Oba barrow, fragment; 11, 12 - barrow 2 Pisochyn burials; 13 - Grave $1 \mathrm{~b}$ from Necropolis at Nymphaeum

Наведені приклади досить виразно дозволяють побачити, що на задум пекторалі 3 Товстої Могили вплинули різноманітні і різнорідні твори мистецтва, 3 яких багато ідей могли бути використані майстром при виготовленні шедевра. Однак сліди подібних запозичень практично не простежуються в композиції, сюжетах і образах пекторалі з Великої Близниці. Інакше кажучи, створення пекторалі з Товстої Могили було обумовлене не тільки високою технічною i художньою майстерністю торевта, а i його широким кругозором. Навряд чи таким же чином можна охарактеризувати і майстра пекторалі з Великої Близниці - значна частина ідей могла бути запозичена ним безпосередньо від пекторалі з Товстої Могили, знайомство з якою видається дуже вірогідним.

Одним 3 найбільш помітних елементів схожості двох пекторалей, зазначеним багатьма дослідниками, є сцени погоні собаки за зайцем, що розміщені по кутам образотворчих фризів (рис. 5: 1-4). Але за удаваною зовнішньою схожістю виявляється і ряд відмінностей. Даний сюжет - гонитва собаки за зайцем - був втілений на різноманітних предметах 3 різного матеріалу, вирізняючись при цьому стійкою канонічністю (рис. 5: 5-9) ${ }^{15}$. У всіх випадках сцена динамічна собака жене зайця, який стрімко втікає. На таманській же пекторалі заєць причаївся, притиснувши голову до передніх лап, що ще Л.Е. Стефані здавалося дивним [Стефани 1871, с. 19]. Ця різниця була відзначена лише деякими дослідниками [Полидович, Вольная 2005, с. 421; Гаврилюк, Тимченко 2015, с. 104] ${ }^{16}$. На думку Н.О. Гаврилюк і М.П. Тимченка, зайці зображені «притаившимися, еще не вспугнутыми», хоча тут же, порівнюючи їх із зображеннями епохи пізньої бронзи на рельєфах Воріт сфінкса з Аладжа-Хююка, визначають їх як символ слабкого й боягузливого противника [Гаврилюк, Тимченко 2015, с. 113]. Запропонована іконографічна паралель 3 точки зору культурного контексту не дуже вдала, враховуючи як хронологічну, так $\mathrm{i}$ територіальну віддаленість аналогії. У подібній позі зайців можна побачити на численній серії пластинчастих аплікацій (варіант 2 групи 2 за Ю.Б. Полідовичем і Г.М. Вольною [Полидович, Вольная 2005, с. 418]), а також на золотій бляшці з Куль-Оби зі сценою полювання вершника на зайця [Piotrovsky and etc. 1986, pl. 197] (рис. 5: 10-13). Також Н.О. Гаврилюк і М.П. Тимченко вважають, що сцени переслідування зайця собакою на обох пекторалях свідчать про близьке знайомство торевтів зі звичками звірів, що також не безперечно. Сцена гонитви на пекторалі 3 Товстої Могили вказує, скоріш за все, на знайомство торевта з образотворчим каноном, втіленим ним в техніці литва на найвищому художньому рівні. Сцена на таманській пекторалі $\epsilon$ безсумнівною реплікою сюжету, репрезентованого на прикрасі з Товстої Могили. Але, в той же

${ }^{15}$ Сцени гонитви собаки за зайцем зображені на оббивках горитів чортомлицької серії, причому найбільш повна версія цієї сцени відтворена на гориті з Мелітопольського кургану [Черненко 1981, рис. 53, 54, 56, 58], накладці кістяного гребеня з Куль-Оби [Piotrovsky etc. 1986, pl. 214], золотий блясі 3 Феттерсфельде (Віташково) [Nawroth 2007, Abb. 3], хрестоподібній блясі з Салонта [Кemeczei 2009, Taf. 59: 18], червонофігурному аскосі 3 Німфейского могильника (музей Оксфордського університету) [Vickers 2002, p. 29, pl. 8].

${ }^{16}$ Г.І. Соколов цю сцену пекторалі порівнював 3 «детской чистотой восприятия мира» - «... зайцы, которых травят собаки, не убегают, а сжимаются в комочек, как будто наивно полагают, что смогут избежать гибели» [Соколов 1997, с. 404]. 
час, очевидний відхід від канонічної версії гонитви через заміну зайця, що біжить, на того, що сидить. Цей образ був, скоріш за все, запозичений з іншого образотворчого канону, а не відтворений через спостереження за живою природою. Це внесло в саму сцену інший зміст собака не переслідує зайця, а заграє 3 ним, торкаючись лапою його стегна, що частково узгоджується з відомим сюжетом байки Езопа [Полидович, Вольная 2005, с. 427].
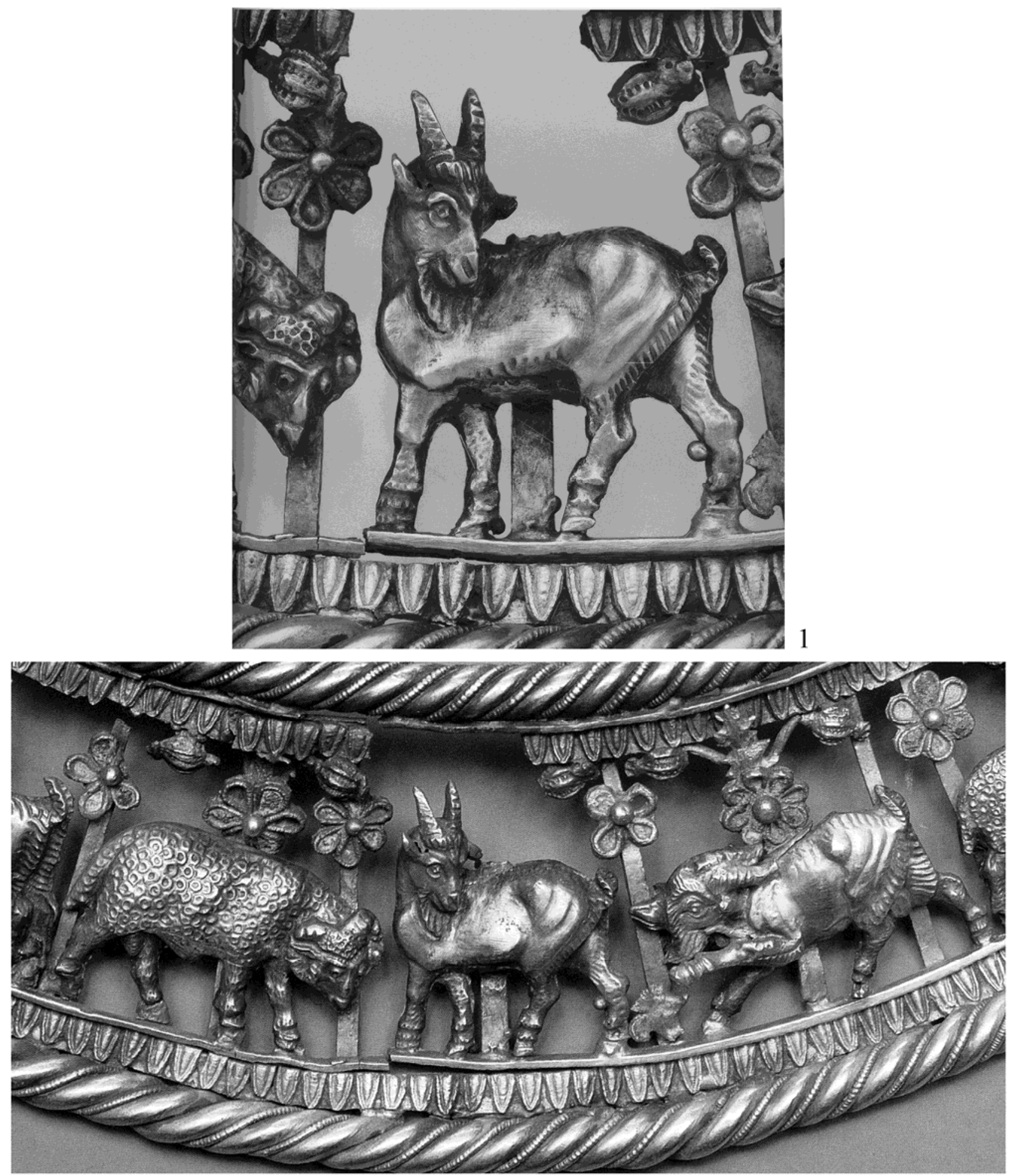

Рис. 6. Пектораль з Великої Близниці:

1, 2 - фрагменти [Калашник 2014, с. 191; Piotrovsky and etc. 1986, pl. 256]

Fig. 6. Pectoral from the Velyka Blyznytsia: 1, 2 - fragments 

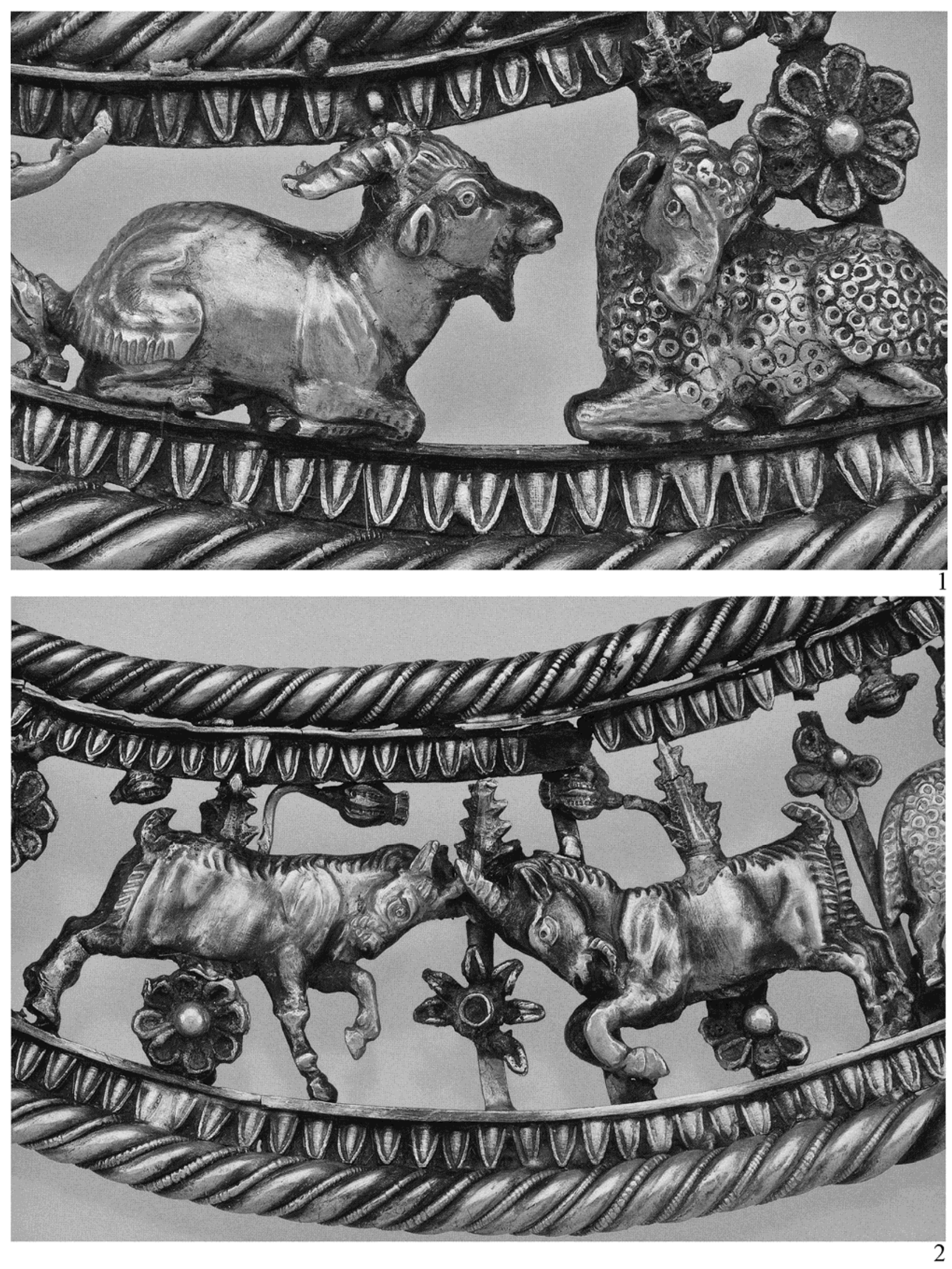

Рис. 7. Пектораль з Великої Близниці: 1, 2 - фрагменти [Калашник 2014, с. 189, 192]

Fig. 7. Pectoral from the Velyka Blyznytsia: 1, 2 - fragments 

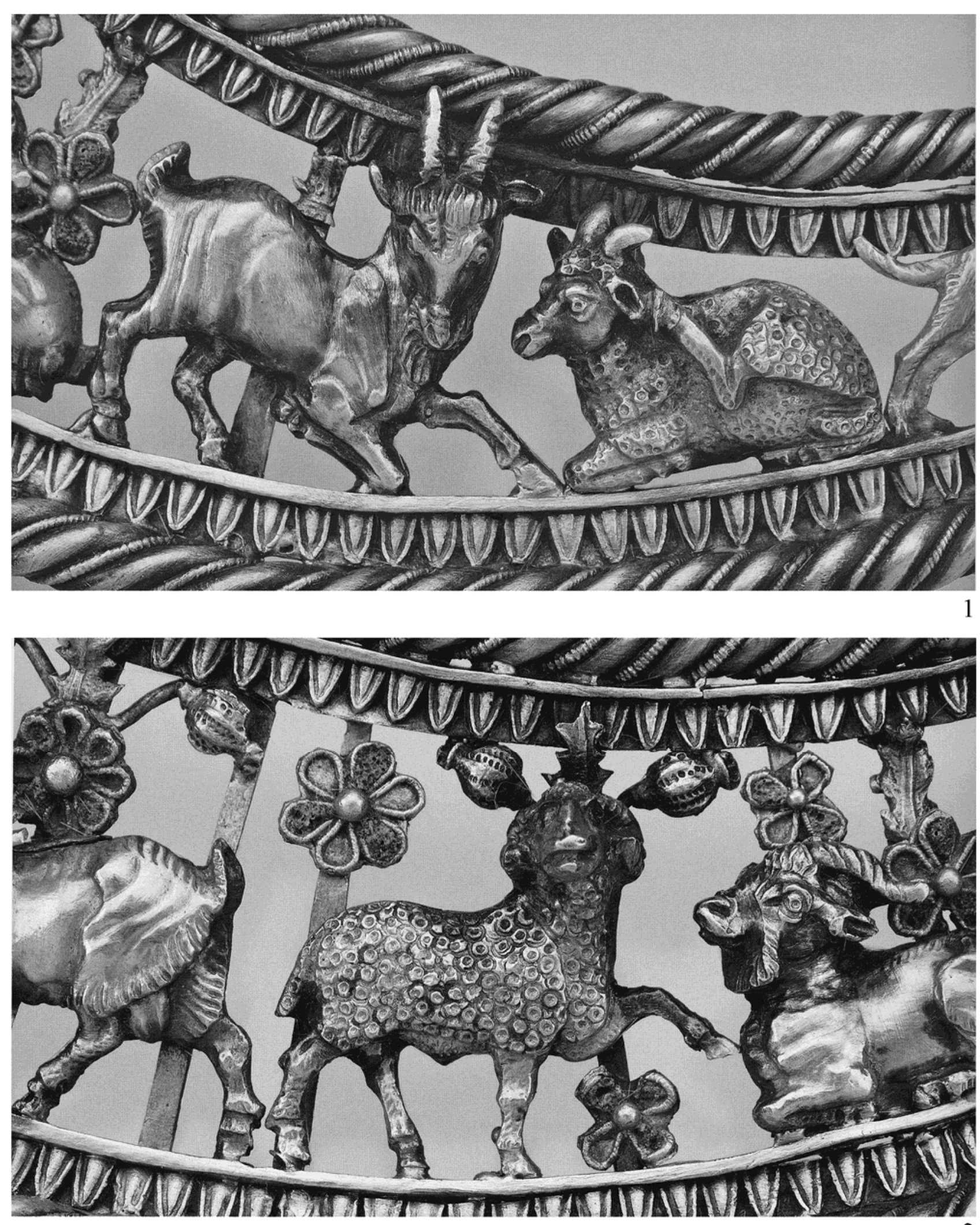

Рис. 8. Пектораль з Великої Близниці: 1, 2 - фрагменти [Калашник 2014, с. 190]

Fig. 8. Pectoral from the Velyka Blyznytsia: 1, 2 - fragments

Зіставлення художньої досконалості сцен гонитви собаки за зайцем безумовно свідчить про неоднаковий рівень майстерності, i, вкотре, про різне авторство обох пекторалей. Але грубуватість фігурок собаки і зайця на пекторалі з Великої Близниці відчутно дисонує не 
тільки 3 шедеврами мікропластики прикраси з Товстої Могили, а й зі скульптурами цапів $\mathrm{i}$ баранів на самій таманській пекторалі. Створюється враження, що це або твори різних майстрів, або торевт повністю знехтував естетикою фігурок собаки і зайця, відводячи їм допоміжну декоративну функцію.

Найбільш видовищну i, поза сумнівом, оригінальну частину композиції пекторалі 3 Великої Близниці складають 11 фігурок цапів і баранів, розташованих у різних позах по всій довжині образотворчого фризу (рис. 6-8). Разом $з$ пектораллю $з$ Товстої Могили та амфорою 3 Чортомлика таманська пектораль становить рідкісну групу предметів торевтики, прикрашених фігурками худоби, причому на відміну від перших двох випадків, в цих сценах відсутні людські персонажі. Тварин цієї пекторалі вирізняє і деяка статева і видова невизначеність. Якщо на пекторалі з Товстої Могили навіть у випадках відсутності помітних статевих ознак наявність потомства апріорі вказує на приналежність дорослих тварин до самок, то на таманській пекторалі статева атрибуція тварин не має такої жорсткої визначеності. Як наслідок, дослідники припускають як одностатевий (або вівизі і кози [Артамонов 1966, с. 72; Манцевич 1974, с. 93; Раевский 1978, с. 118; Мозолевский 1979, с. 213; Бессонова 1983, с. 72; Гаврилюк 1999, с. 146, 147; Русяєва 2008, с. 523; Гаврилюк, Тимченко 2015, с. 99], або барани і цапи [Стефани 1871, с. 18; Толстой, Кондаков 1889, с. 59; Гайдукевич 1949, с. 290; Цветаева 1968, с. 73; Мачинский 1978, с. 138; Калашник 2014, с. 189], варіант - «козлики і барашки» [Соколов 1999, с. 212]), так і в усяких поєднаннях різностатевий (барани, цапи, кози [Михайлин 2005, с. 80], барани, вівці, цапи [Трейстер 2010, с. 555], вівці, цуапи, кози [Гребнев 2007, с. 290, 291]) склад худоби.

Немає одностайності і стосовно видової належності тварин. Не викликає сумнівів атрибуція 7 цапів / кіз і 2 баранів. Морфологія ще двох тварин - крайньої праворуч і другої 3 лівого краю (від глядача) - амбівалентна. Характер трактування вовни тварин - у вигляді кружечків з поглибленням в центрі - ідентичний хутру баранів у центрі композиції. Але голівки тварин з короткими ріжками ближче цапиним. Л.Е. Стефані розглядав цих тварин як баранів [Стефани 1871, с. 18]. А.П. Манцевич тварину, що чеше морду, вважала цапом [Манцевич 1980, с. 107]. М.Ю. Трейстер, який побачив серед тварин «цапів, баранів, овець», вважав, з контексту пасажу, їх вівцями. Н.О. Гаврилюк різний характер вовни кіз на двох пекторалях трактувала як ознаку двох порід - пухових (Товста Могила) і вовняних (Велика Близниця) [Гаврилюк 1999, с. 147]. Беручи до уваги помітну різницю вовни основного козлиного стада від двох «проблемних» персонажів пекторалі з Великої Близниці, можна припустити, що дослідниця не бачила в них представників цього виду. У більш пізній роботі ця проблема була вирішена по-іншому - на пекторалі визначені тільки 9 з 11 тварин - 7 кіз і 2 вівці, ще ж двох тварин автори «забули» згадати [Гаврилюк, Тимченко 2015, с. 99]. Найбільш грунтовний аналіз складу козлиного стада на пекторалі з Великої Близниці зробив Я.В. Гребньов, який побачив там 9 кіз трьох різних порід. На думку дослідника 7 кіз і цапів відносяться до молочного або грубошерстного типу і представлені двома породами з рогами типу безоарового козла (рис. 9: 1, 4) і з рогами типу «пріска» (рис. 9: 2, 5). Ще 2 кози - 3 «баранячою» вовною - нагадують Я.В. Гребньову «представників сучасної придонських породи» (рис. 9: 3, б) [Гребнев 2007, с. 290, 291].

Попри можливу правдоподібність подібних визначень, необхідно все ж мати на увазі, що зображення тварин на пекторалі виконані в стилізованому вигляді і тому ті чи інші збіги або відмінності від природного прототипу можуть бути досить умовними. Не виключено, що своєрідний симбіоз морфології цих двох тварин мав навмисний характер, можливих причини якого торкнемося нижче.

Показово, якщо до розкопок Товстої Могили дослідники незмінно захоплювалися жвавістю «схоплених 3 натури» тварин на пекторалі 3 Великої Близниці [Толстой, Кондаков 1889 , с. 59 ; Гайдукевич 1949, с. 290; Цветаева 1968, с. 73], то вже опісля, на контрасті між двома пекторалями, бачили їх кремезними і негнучкими, з застиглими позами [Schwarzmaier 1996, S. 127; Русяєва 2008, с. 523]. Подібна оцінка навряд чи справедлива, втім, 

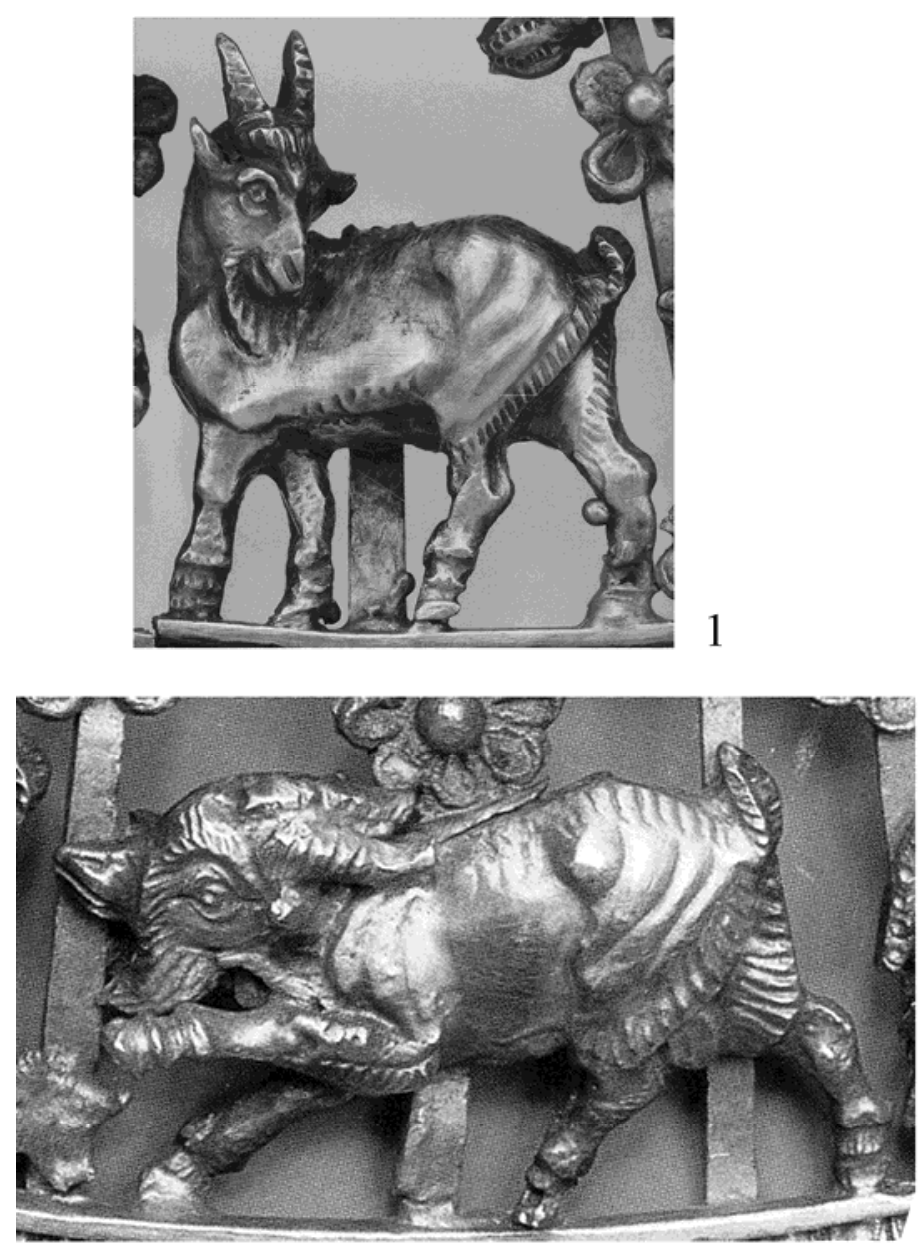

2

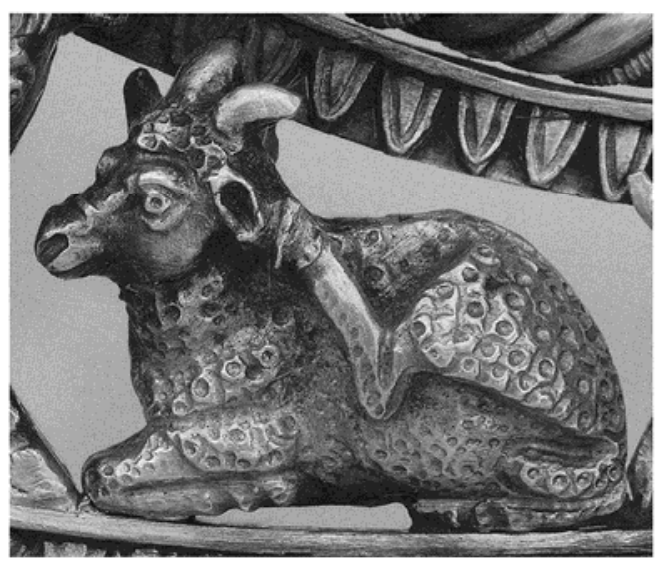

3
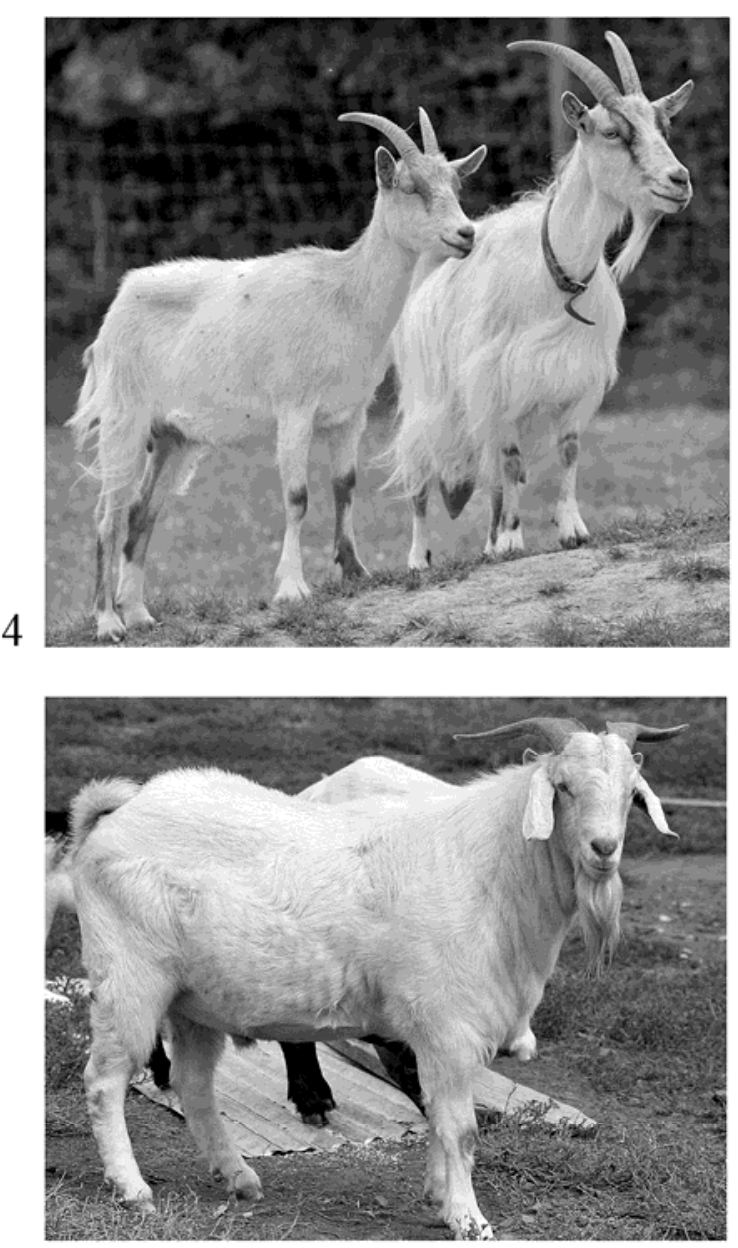

5

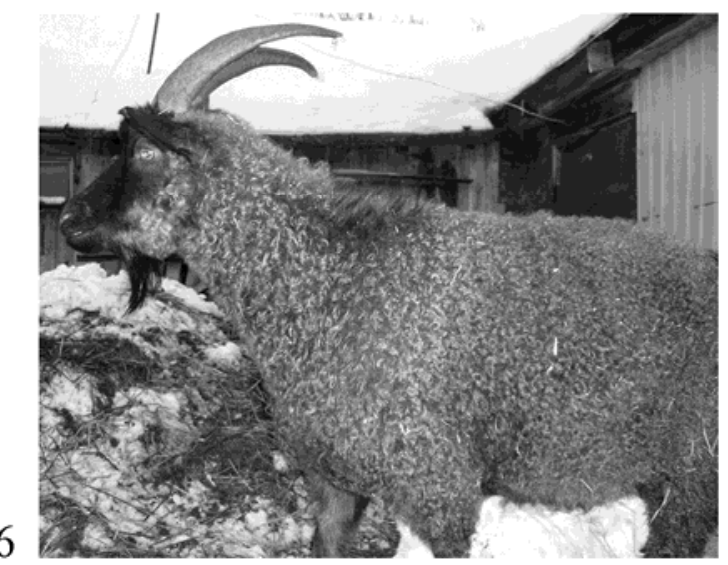

Рис. 9. Відповідність порід кіз на пекторалі з Великої Близниці природним прототипам:

$\mathbf{1 , 4}$ - тварини з рогами типу безоарового козла; $\mathbf{2}, \mathbf{5}$ - козли з рогами типу «пріска»; $\mathbf{3 , 6}$ - козли сучасної придонської породи [Калашник 2014, с. 190, 191; Piotrovsky and etc. 1986, pl. 256]

Fig. 9. Correspondence of goat breeds on pectoral from the Velyka Blyznytsia to natural prototypes:

$\mathbf{1 , 4}$ - animals with horns such as bezoar ibex; $\mathbf{2}, \mathbf{5}$ - goats with horn type «prisca»;

$\mathbf{3 , 6}$ - goats of modern breed «prydonska»

вона не одностайна (порівн.: [Соколов 1997, с. 404; 1999, с. 212; Калашник 2014, с. 189]). Порівнювати художню стилістику тварин двох пекторалей в контексті їх більшої або меншої відповідності природним прототипам навряд чи коректно. На пекторалі з Товстої Могили, а також на чортомлицькій вазі і багатьох інших виробах художники прагнули до реалістичної манери зображення тварин, відмінної від традицій власне скіфського звіриного стилю. Всі 


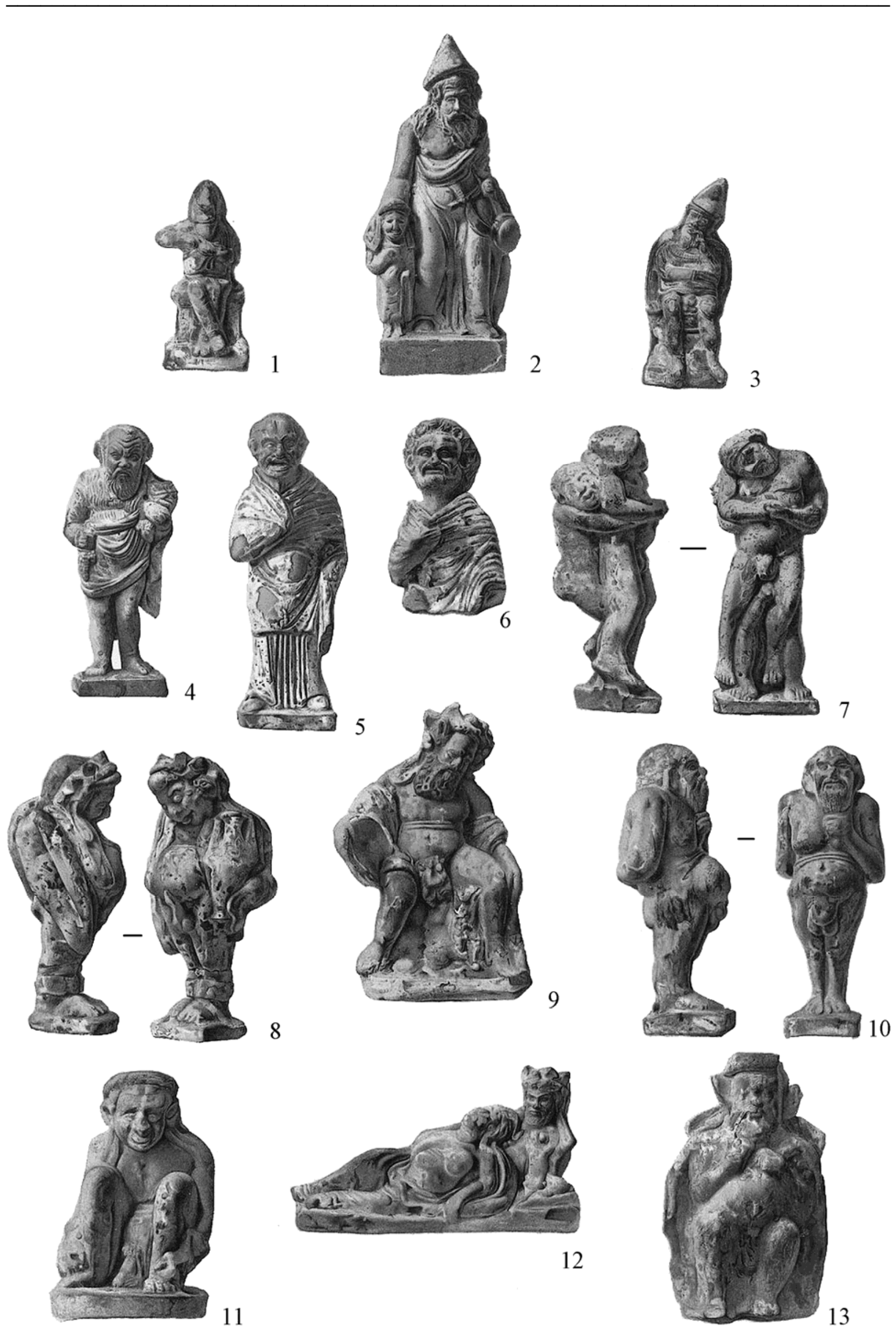

Рис. 10. Теракотові статуетки зі склепу № 4 Великої Близниці (1-13) [ОАК за 1869 год, 1871, табл. II] Fig. 10. Terracotta figurines from tomb № 4 the Velyka Blyznytsia 
Донецький археологічний збірник. - 2019. - № 22. - С. 102-142.

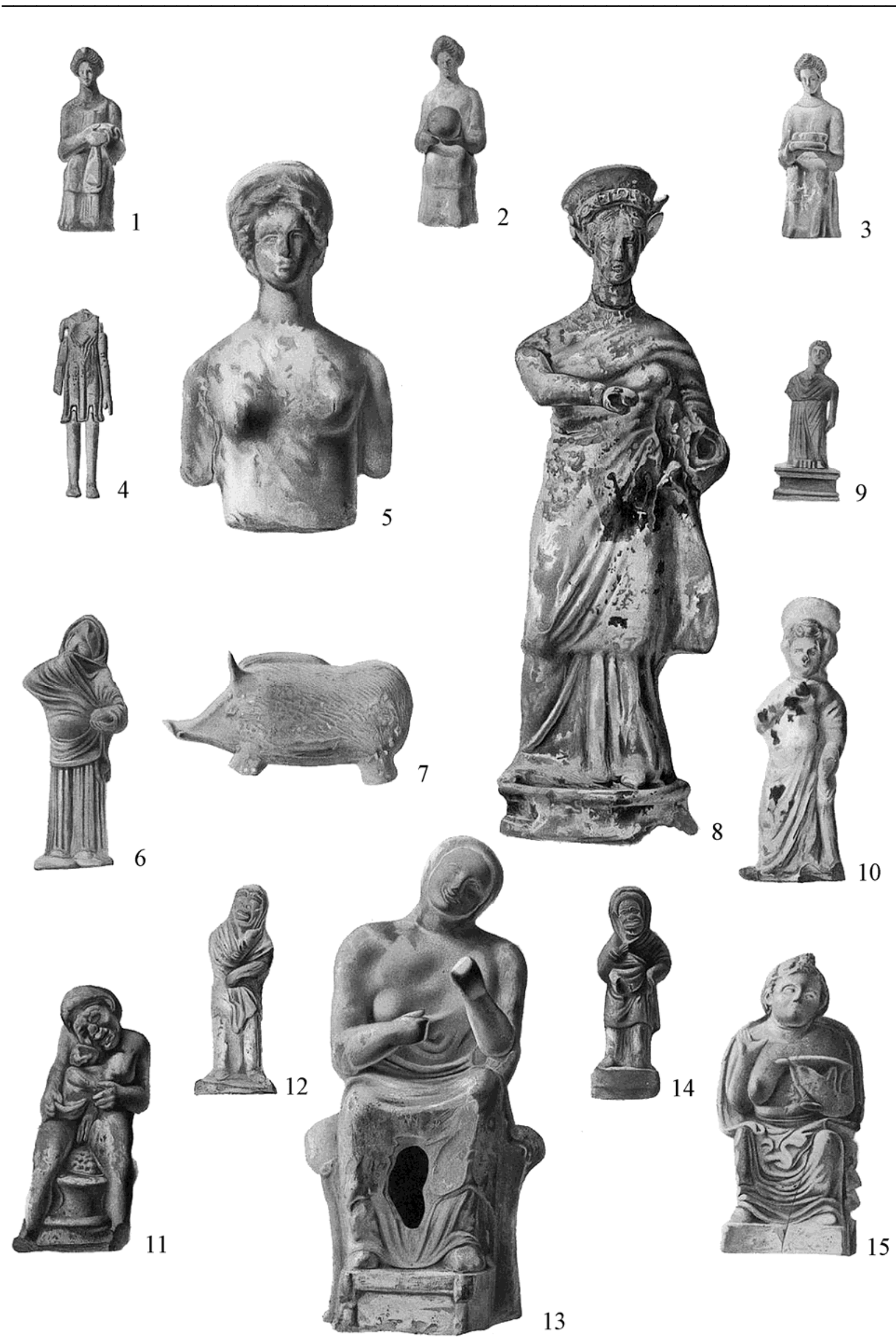

Рис. 11. Теракотові статуетки зі склепу № 4 Великої Близниці (1-15) [ОАК за 1869 год, 1871, табл. III] Fig. 11. Terracotta figurines from tomb № 4 the Velyka Blyznytsia 
фігурки баранів і цапів на пекторалі з Великої Близниці виконані в інший, абсолютно оригінальній стилістиці. Самобутністю стилю цапи і барани виділяються навіть на тлі розглянутих вище скульптурок собак і зайців, які, незважаючи на грубуватість, є прикладом реалістичного трактування тварин.

Як було сказано вище, в позах деяких тварин таманської пекторалі помітні явні алюзії на сюжети пекторалі з Товстої Могили (тварина, що чеше вухо, коза, яка піднімається 3 упором на коліно), що було відзначено неодноразово [Манцевич 1980, с. 107; Русяєва 2008, с. 523; Бабенко 2017, с. 32]. Багато дослідників, характеризуючи сцени таманської пекторалі, бачили в них «резвящихся» тварин [Мачинский 1978, с. 138; Бессонова 1983, с. 72], урочисто виступаючого барана або цапа, що заграє 3 лежачою козою [Михайлин 2005, с. 80]. Подібному «олюдненню» створених художником образів сприяють індивідуальні риси кожної з тварин, особливий характер і емоційний стан яких дуже виразно вдалося передати торевту.

Серед витворів мистецтва, що дійшли до наших днів, важко вказати хоча б ще один вироб, прикрашений зображеннями тварин у подібній стилістиці ${ }^{17}$. Якщо осучаснити характеристику враження, яке справляють цапи і барани пекторалі, то можна відзначити їх схожість - і за зовнішнім виглядом, і за переданими рухами - 3 героями анімаційних фільмів для дітей ${ }^{18}$. Визначаючи характер їх стилістики, можна говорити не про реалістичну, а про гротескну, карикатурну манеру зображення тварин. Якщо коло пошуку аналогій не обмежувати предметами торевтики і анімалістичними сюжетами, а в якості критерію для визначення ймовірних робіт художника використовувати таку рису індивідуального художнього стилю майстра як гротескність створюваних ним образів, то слід звернути увагу на дуже примітний комплекс з 32 теракот, виявлених у цьому ж склепі № 4 Великої Близниці (рис. 10; 11).

Специфічною рисою цього набору теракотових статуеток, що вирізняються великим розмаїттям типів, є зазначена багатьма дослідниками «гротескність», «карикатурність», «потворність» створених художниками образів [Гайдукевич 1949, с. 290; Передольская 1950, c. 255,$256 ; 1962$, с. 46 ; Артамонов 1966 , с. 72 ; Грач 1974, с. 36 ; Соколов 1997, с. 400-420; 1999, с. 210; Ходза 2006, с. 165]. В цілому, перші зразки гротеску в давньогрецькому мистецтві можна побачити на аттичному вазовому живопису кінця VI-V ст. до н.е. [Ходза 2006, с. 156-162]. Але особливо яскраво цей напрям мистецтва проявився вже пізніше в коропластиці, де він репрезентований безліччю виготовлених в подібному жанрі теракот, трактованих найчастіше у вигляді образів комічних акторів давньогрецьких комедій. Зооморфні персонажі в цьому жанрі представлені не безпосередньо тваринами, а фігурками акторів у масках теляти, барана або осла [Ходза 2006, с. 75]. Однак для боспорської торевтики, тим більше по відношенню до образів 3 тваринного світу, гротескний стиль зовсім не характерний, і його використання робить таманську пектораль у цьому контексті прикрасою навіть більш унікальною, ніж пектораль з Товстої Могили.

Новаторство стилю фігурок тварин пекторалі в поєднанні зі знахідкою в цьому ж похованні трьох десятків теракот, виконаних у тому ж жанрі, дозволяє припустити, що подібний збіг міг бути невипадковим. Однак однозначно визначити його характер досить важко. Беручи до уваги широку традицію виготовлення гротескних теракот, їх первинність $\mathrm{i}$ самостійність не викликає сумніву. Ідея карикатурності стилю фігурок пекторалі, швидше за все, була запозичена торевтом у коропласта. Але чи можна допустити, враховуючи оригінальність гротескного стилю, єдине авторство для теракот і фігурок пекторалі?

${ }^{17}$ А. Шварцмайєр порівнювала «статичне і незграбне трактування тварин» на пекторалі 3 Великої Близниці з рельєфними зображеннями на дзеркалах з музею Бенакі в Афінах і Державного античного зібрання в Мюнхені [Schwarzmaier 1996, S. 127-129].

${ }^{18}$ Г.І. Соколов відзначав, що ці «образы ... очаровательны своей почти детской чистотой восприятия мира» [Соколов 1997, с. 404]. 
Незважаючи на очевидну відмінність у техніці, матеріалі, відтворених образах, фігурки i теракоти вирізняє і ряд не менш помітних збігів. I фігурки пекторалі, і теракоти були виробами дрібної пластики. Навичками роботи з глиною, природними для коропласта, повинен був володіти і торевт, що відливав фігурки тварин в техніці одноразової воскової моделі. Про те, що виробнича діяльність коропласта і торевта могла мати точки дотику, свідчать різноманітні позолочені теракотові імітації виробів із золота. Серед цих теракот $\epsilon$ круглі позолочені пластини із зображенням горгонейон, голівок Афіни і розеток. За припущенням О.Н. Ходзи, при виготовленні подібних теракот в якості своєрідної патриці могли використовувати саме золоті бляшки [Ходза 2018, с. 101-108].

Ще один стилістичний нюанс зближує теракотові статуетки і фігурки тварин на пекторалі. Г.І. Соколовим була помічена така риса майстра теракот як «внимание ... к физиономическим особенностям, к выражениям лиц и настроениям» персонажів, яких вирізняє «разнообразие оттенков чувств, запечатленных в чертах ... собравшихся в одну группу людей...» [Соколов 1997, с. 410]. Цю характеристику можна адресувати і фігуркам цапів і баранів на пекторалі.

Водночас не на користь думки про спільне авторство фігурок пекторалі і теракот 3 Великої Близниці може свідчити можливе місце їх виготовлення. Так, боспорське походження таманської пекторалі, беручи до уваги іiі близькість до прикраси з Товстої Могили, видається найбільш імовірним. Єдина думка про місце виготовлення теракот 3 Великої Близниці відсутня. Домінує точка зору про їх аттичне походження (поряд 3 іонійським i фанагорійський) [Передольская 1962, с. 50-52; Грач 1974, с. 36-39], що в принципі не виключає можливості виготовлення фігурок і теракот одним майстром, але все ж робить їі малоймовірною.

Можлива стилістична похідність фігурок пекторалі від теракот зумовлює i їх семантичну кореляцію, яка буде розглянута нижче. В цілому, витонченість, оригінальність $\mathrm{i}$ єдність стилю виготовлених фігурок свідчить про майстерність і вишуканий смак майстра, що різко дисонує з іншим виглядом пекторалі, включаючи фігурки собак і зайців. Не виключено, що до ії виготовлення причетні мінімум два торевти, рівень майстерності яких був різним.

Семантика. Першу спробу осмислення репрезентованих на пекторалі з Великої Близниці образів і сюжетів здійснив Л.Е. Стефані. Дослідник ще на початку огляду знахідок 3 гробниці № 4 Великої Близниці розглядав «большое ожерелье», разом 3 теракотовими статуетками, прикрасами головного убору, набором посуду, як свідоцтва належності похованою до вакхічного культу, що є складовою частиною культу елевсінських божеств [Стефані 1871 , с. 12]. Потім, охарактеризувавши сюжет пекторалі як «сцену сельского и пастушеского быта» [Стефані 1871, с. 18], виклав більш ніж на ста сторінках огляд різноманітних давньогрецьких і римських творів мистецтва (вазового і настінного живопису, гліптики, нумізматики, мармурової і бронзової скульптури, теракот, мармурових рельєфів, світильників, художньо оформленого бронзового посуду і предметів озброєння тощо), що містять зображення цапів і баранів. Репертуар згаданих сюжетів строкатий. Цапи і барани в різних поєднаннях репрезентовані такими, що пасуться чи граються, яких приносять у жертву, у вигляді верхових і в'ючних тварин, супутників персонажів або різноманітних їх інкарнацій. Номенклатура перелічених дослідником міфологічних персонажів, які в тому чи іншому контексті пов'язані з цапами і баранами, також дуже велика. Згадані різні герої (Паріс, Ендіміон, Ромул і Рем, Аттіс, Поліфем, Едіп та ін.) та божества (Деметра і Кора, Аполлон і його діти / Філакід, Філандр, Асклепій /, Артеміда, Геракл, Гермес, Артеміда і Ерот, Діоніс з численним почтом / Пан, Силени, Сатири, Менади, Пріап /, Гермес, Зевс /особливо в контексті міфу про золоте руно/, Гера, Афіна) [Стефані 1871, с. 19-128]. Але в кінці цього докладного синопсису Л. Е. Стефані так і не погодив з сюжетом пекторалі той чи інший персонаж, тому зазначений ним на самому початку зв'язок з вакхічними культами не зазнав змін. 
У наступні понад сто років дослідники, які зверталися до пекторалі з Великої Близниці, обмежувалися лише лаконічною характеристикою «живо схваченных с натуры животных», не докладаючи спроб аналізу смислового змісту сцен [Толстой, Кондаков 1889, с. 59; Гайдукевич 1949, с. 290; Артамонов 1966, с. 72; Цветаева 1968, с. 73].

Навпаки, увага до проблем семантики композиції пекторалі з Товстої Могили проявилася буквально з моменту відкриття прикраси. Вже через декілька років побачили світ три фундаментальні дослідження з цієї тематики [Мачинский 1978; Мозолевський 1978; Раевский 1978]. Згодом кількість семантичних інтерпретацій істотно збільшилася - тільки центральна сцена верхнього фризу налічує більше двох десятків оригінальних тлумачень [Бабенко 2013, с. 111-113]. При цьому для підтвердження тих чи інших трактувань багато дослідників досить часто проводили паралелі саме з сюжетами пекторалі з Великої Близниці. Подібні зіставлення набули характеру стійкої традиції, хоча далеко не всі 3 них можна визнати безперечними. Розглянемо деякі з них.

Семантику композиції пекторалі з Товстої Могили в цілому визначає іiі тернарна структура 3 протиставленням сюжетів верхнього і нижнього фризів за допомогою ряду бінарних опозицій, перш за все мотивів народження і смерті. Найбільш універсальне трактування композиції було запропоноване Д.С. Раєвським, який побачив в ній розгорнуте втілення скіфської космологічної моделі [Раевский 1978; 1985, с. 181-203, 229-233]. Порівнюючи обидві пекторалі, багато дослідників спробували пояснити композицію таманської пекторалі як скорочений, «збіднений» варіант, «конспект» пекторалі з Товстої Могили. При цьому верхній фриз найчастіше співвідносився зі сценами 3 домашніми тваринами, нижній - зі сценою переслідування зайця собакою, середній - 3 рослинними композиціями [Мачинский 1978, с. 145; Раевский 1978, с. 118; 1985, с. 230, 231; Brentjes 1994, S. 176]. На некоректність подібних зіставлень дослідники вже вказували [Fornasier 1997, S. 123-125; Михайлин 2005, с. 79, 80]. Але їх штучність стає ще виразнішою, якщо спробувати розпізнати елементи космограми в композиції таманської пекторалі, абстрагуючись при цьому від пекторалі 3 Товстої Могили. Показова відсутність структурності в композиції прикраси 3 Великої Близниці ${ }^{19}$. Образи, яким намагаються знайти більш-менш придатну відповідність кожному 3 трьох фризів, не відбивають стрижневих ідей, що маркують ту чи іншу зону світобудови. Відсутність сцен, що містять ідеї народження, очевидна. Навряд чи їх еквівалентом можна сприйняти «шлюбні ігри тварин» [Раевский 1985, с. 230], навіть через спірність такого трактування [Михайлин 2005, с. 79, 80]. Про хиткість «шлюбного» характеру периферійних пар свідчить і зазначена вище неоднозначність видової приналежності деяких тварин. Малоймовірно, що майстер-торевт, яким далеким він не був би від нюансів практичного скотарства, використовував для відтворення «шлюбних пар» тварин різного виду. Так само це стосується і до теми смерті, репрезентованої сценою гонитви собаки за зайцем. Навіть в композиції пекторалі з Товстої Могили ця сцена трактується неоднозначно, можлива навіть іiі трансформація на периферії «світу смерті» в життєстверджуючу ідею [Полидович 2006, с. 83]. Ще складніше для визначення тлумачення змісту цих сцен в композиції таманської пекторалі, відокремлених від «світу смерті», в силу можливої широкої варіативності значення цього сюжету [Полидович 2007, с. 93-99; Полидович, Вольная 2005, с. 426-428] чи його самостійності [Fornasier 1997, S. 124-125]. На думку Н.В. Молевої сцени гонитви собаки за зайцем на двох

${ }^{19}$ Більш виразно тернарну структуру можна побачити не в композиції пекторалі, а в наборі нагрудних прикрас 3 даного поховального комплексу. До складу прикрас небіжчиці, крім пекторалі, входили ще два намиста, набраних з пронизок, намистин, підвісок, оформлених у вигляді різних антропо-, зоо- та фітоморфних образів. При цьому, на одному намисті превалює рослинна тематика (розетки, підвіски-бутони), друге вирізняе репрезентативна номенклатура образів (горгонейони, голови бородатих сатирів, негрів, баранів, жаби, цикади, виноградні грона, астрагали). Цілком ймовірно, що семантика сюжетів і образів трьох прикрас була узгоджена, але навряд чи вона була пов'язана з ідеями світового дерева. 
пекторалях наповнені певним протилежним змістом - на пекторалі 3 Товстої Могили тварини намагаються залишити «світ смерті», на таманській пекторалі - «світ життя» [Молева 2017, с. 84].

У структурі пекторалі як образотворчої космограми, середній фриз з рослинними пагонами «служит главным организующим элементом, связующим верхний и нижний фризы (resp. верхний и нижний миры), что соответствует функции мирового дерева» $\left[\right.$ Раевский 1985, с. 200] ${ }^{20}$. У композиції пекторалі з Великої Близниці рослинні мотиви чітко не структуровані, не організовані просторово (відсутня будь-яка видимість центральної осі), $\mathrm{i}$ ïx смисловий зміст може мати зовсім інше наповнення.

Нарешті, є спроби «відсутні» елементи композиції таманської пекторалі відшукати серед інших предметів поховального комплексу. Б. Брентьєс брак виразних «сцен боротьби» на пекторалі спробував заповнити сценами битви на золотому калафі [Brentjes 1994, S. 176], що не знайшло підтримки [Fornasier 1997, S. 123-125]. Слід зазначити, що можлива наявність семантичного взаємозв'язку між різними предметами поховального комплексу була декларована багатьма дослідниками ${ }^{21}$. Але в цьому випадку обидва предмети - пектораль $\mathrm{i}$ калаф (з гробниці 1) - походять 3 різних поховань, і навіть 3 цієї причини ставити питання про можливий семантичний зв'язок між ними некоректно.

В.Ю. Михайлин сюжет пекторалі з Товстої Могили трактував як образотворчу версію триступеневої соціальної ініціації героя через статусне полювання на тварин трьох видів $\mathrm{i}$ триразової жертви, що забезпечувала перехід до більш високого статусу. У контексті цієї реконструкції був прочитаний і сюжет таманської пекторалі, а похована в гробниці № 4 Великої Близниці інтерпретована як не «дорослий скіфський цар», а «принц», який навічно залишився в першій, «собачо-заячій» стадії військової ініціації» [Михайлин 2005, с. 80]. Подібне трактування є наслідком ігнорування дослідником історичного і археологічного контексту пам'ятки. Слід мати на увазі, що поховання Великої Близниці належало не скіфському царю або принцу, а швидше вже «принцесі», представниці шляхетного боспорського роду. Уже це спростовує запропоновані автором тлумачення. Не можна погодитися і з неаргументованими сумнівами В.Ю. Михайлина щодо жрецької інтерпретації цього поховання [Михайлин 2005, с. 80, прим. 2]. Думка 3 цього приводу у дослідників вирізняється рідкісною одностайністю 22.

Зображення торевтами в композиції обох пекторалей худоби в «табуні» чи «стаді» дійсно виокремлює обидві прикраси (разом з чортомлицькою амфорою) на тлі інших творів мистецтва. Але в контексті семантичних трактувань цих образів настільки ж виразна i їх відмінність. Репрезентативний склад домашніх тварин верхнього фризу пекторалі з Товстої Могили та його сувора ієрархія дозволили тлумачити композицію як втілення ідеї «пяти частей скота», «всескотия», сліди якої можна виявити в індійській, іранській та інших традиціях («Чхандогья упанішада», «Артхашастра», «Рігведа» та ін.) [Раевский 1985, с. 193195; Никольская 2005-2009]. Подібні визначення зовсім не пасують неранжованому «стаду» таманської пекторалі, що складається лише з цапів і баранів без чіткої ієрархії.

Ряд сюжетів і образів пекторалі з Товстої Могили трактуються в контексті календарної, перш за все, новорічної (весняної) символіки (сцени шматування як символ весняного оновлення і відродження, сцени годівлі молодняку як маркер весняної календарної дати ${ }^{23}$ та ін.) [Бессонова 1983, с. 70-74; Мозолевський 1979, с. 225; Раевский 1985, с. 196; Кузьмина 1984, с. 105-108; 1987, с. 3-12; Петрухин 2001; Бабенко 2013, с. 114-117]. Оманлива схожість сюжетів сприяла і близькій інтерпретації сцен таманської пекторалі як «весняного

${ }^{20}$ Порівн.: [Мачинский 1978, с.144, 145; Михайлин 2005, с. 34, 35, 117, 174; Gebauer 1997].

${ }^{21}$ Деякі приклади див.: [Бабенко 2016, с. 12].

22 Докладніше див.: прим. 26.

${ }^{23}$ Інша думка про можливу календарну дату у Н.О. Гаврилюк і М.П. Тимченка. Вони вважають, що молодняк уже підріс і це свідчить про іншу календарну дату - кінець весни - початок літа [Гаврилюк, Тимченко 2015, с. 106, 107]. 
вигону худоби на пасовище» [Бессонова 1983, с. 71, 72]. Однак відсутність у цих сценах молодняку робить таке тлумачення малопереконливим. Якщо ж погодитися з трактуванням цих сцен як «шлюбних ігор» [Раевский 1978, с. 118; 1985, с. 230], тобто таких, що передують паруванню тварин, і співвіднести термін вагітності (близько 5 місяців) та передбачуваного часу окоту (кінець зими - рання весна), то найбільш вірогідною порою року слід визнати осінь. Але ця календарна дата не узгоджується, в свою чергу, з часом цвітіння маку, найбільш характерним для кінця весни та початку літа ${ }^{24}$. Ймовірно, якщо в сюжетах таманської пекторалі і $є$ акцент на календарну символіку, він менш виразний і вказує на іншу пору року.

Багато дослідників центральну сцену верхнього фризу пекторалі з Товстої Могили пов'язували з культом хварна/фарна, матеріальним втіленням якого бачили баранячу шкуру / сорочку з баранячого хутра [Мошинский 2002, с. 85; Михайлин 2005, с. 118-176; Полидович 2006; Шауб 2007; Бабенко 2013, с. 118, 119; Вертієнко 2015, с. 40, 95]. Присутність двох або навіть чотирьох баранів на таманській пекторалі сприяла залученню цих сцен у якості ще однієї наочної ілюстрації поширення культу хварна/фарна [Михайлин 2005, с. 80; Шауб 2007, с. 128]. Подібні тлумачення не можна визнати переконливими. Барани на пекторалі не домінують ні кількісно, ні композиційно. Якщо ж вважати цапів семантичним еквівалентом баранів [Шауб 2007, с. 128], то число символів матеріального втілення божественної благодаті в межах однієї прикраси, що відрізняються до того ж множинністю сюжетних трактувань, може здатися надмірною. Але більш за все такому тлумаченню суперечить соціальний контекст поховальних комплексів. Поховання в Товстій Могилі належало представнику вищої скіфської аристократії, можливо, передчасно померлому спадкоємцю Атея, чим i пояснюється незвичайне місце розташування пекторалі в дромосі [Мошинский 2002, с. 87]. Тому пектораль, як матеріальне втілення хварна/фарна, пасувала похованому за статусом. Загальновизнано, що Велика Близниця була усипальницею представників шляхетної боспорської родини, які виконували певні жрецькі функції (насамперед, склепи 1 і 4). При великому розмаїтті думок про культи, жрицями яких могли бути поховані жінки, культ хварна/фарна як давньоіранська традиція не зовсім узгоджується 3 культурним контекстом. Показово, що І.Ю. Шауб, згадавши окремі предмети 3 Великої Близниці (крім пекторалі - золоті браслети) в зв'язку з уявленнями про хварн/фарн [Шауб 2007, с. 126, 128], в спеціальних дослідженнях, присвячених семантиці знахідок цього кургану, культ хварна/фарна не згадав [Шауб 1987; 2007, с. 370-385]. Ймовірно, не кожне зображення барана слід вважати символом хварна/фарна.

Таким чином, відкриття у Товстій Могилі пекторалі спричинило підвищену увагу до таманської прикраси і одночасно обумовило певну від неї залежність. Конструктивна i частково художня схожість двох пекторалей мимоволі зумовила стійку думку про їх семантичну тотожність, щонайменше, в частині трактувань. Тим часом, семантика композиції таманської пекторалі може мати абсолютно самостійне, незалежне від сюжетів пекторалі з Товстої Могили трактування. Ключем до її розуміння можуть слугувати декілька факторів. Поза сумнівом, найбільш змістовною для семантичних трактувань $є$ саме високохудожня частина композиції пекторалі з Великої Близниці, а саме п'ять сцен за участю цапів i баранів. Художній рівень інших частин пекторалі, що обрамляють основне композиційне поле, істотно нижчий, і саме серед них найбільш помітні елементи наслідування пекторалі з Товстої Могили.

Також семантику пекторалі 3 Великої Близниці слід узгоджувати 3 контекстом поховального комплексу гробниці № 4. Як зазначалося вище, в історіографії не склалося єдиної точки зору про те, якому культу прислуговували поховані жриці. Докладний огляд думок з цієї проблеми викладено І.Ю. Шаубом [Шауб 1987; 2007, с. 370-385], що дозволяє

${ }^{24}$ Але при цьому можливий зв'язок квітів маку з осінньою порою - рослини були створені богами для блукаючої Деметри для здобуття нею спокою і відпочинку [Топоров 2011, с. 389-392]. 
обмежитися короткою їх характеристикою, акцентуючи увагу на окремих моментах. На думку Л.Е. Стефані, поховані в кургані жінки були жрицями культу Деметри та інших елевсінських богів [Стефани 1865; 1871, с. 12]. Але саме по відношенню до жриці з гробниці № 4 дослідник неодноразово, вказуючи на знахідки теракотових статуеток, калафу 3 фігурками менад, пекторалі, бронзових і теракотових судин, підкреслював її «пристрастие к вакхическому культу» [Стефани 1871, с. 12, 17].

M.І. Ростовцев відзначив «связь обеих женщин с культом Великого женского божества ... сближенного с элевсино-орфическим культом Деметры или Коры» [Ростовцев 1925, с. 372]. В.Ф. Гайдукевич вважав, що в кургані були поховані жриці Афродіти святилища Апатура [Гайдукевич 1949, с. 214]. Таку ж думку висловила і Н.П. Розанова [Розанова 1951, с. 212, 213]. 3 елевсінськими культами пов'язував поховання Великої Близниці M.I. Артамонов [Артамонов 1966, с. 69-74].

Першорядне значення у визначенні культу, служницею якого була жінка 3 гробниці № 4, має атрибуція комплексу теракотових статуеток. А.О. Передольська присвятила цим предметів серію робіт і розглядала їх як єдиний комплекс, що належав до культу великих елевсінських містерій на честь Кори і Деметри [Передольская 1950; 1955; 1962 ]. П. Александреску піддав критиці ці висновки і трактував комплекс теракот як приклад синкретизму діонісійської течії і місцевого аграрного культу Великої богині [Alexandrescu 1966, p. 75,76], отримавши підтримку ряду дослідників [Грач 1974, с. 36; Шауб 2007, с. 377]. Г.І. Соколов поділяв думку про зв'язок теракотових статуеток 3 елевсінськими культами, але в той же час вважав, що деякі статуетки могли мати відношення до культу кабірів, Діоніса та Афродіти [Соколов 1997, с. 403]. У похованій у склепі 1 бачать жрицю Артеміди [Фиалко 2004, с. 51; 2011, с. 90].

На підставі комплексного аналізу поховального інвентарю, І.Ю. Шауб також прийшов до висновку про синкретичний характер культу жриць з Великої Близниці та зазначив ряд сюжетів, в яких наочно простежується зв'язок з місцевими культами. Так, предмети 3 різноманітною амазонською тематикою і змієногими персонажами пов'язані, на думку дослідника, з місцевим Великим жіночим божеством у хтонічному аспекті, вуздечні набори, прикрашені образом коня-оленя, і бляшка зі сценою шматування барса грифогіппокампом зі скіфським світом [Шауб 1991; 2007, с. 370-385].

Подібна строкатість думок у визначенні культу, якому прислуговували жриці з Великої Близниці, є живильним середовищем для всіляких трактувань передбачуваної семантики сюжетів і образів пекторалі. Одне 3 таких тлумачень у гранично лаконічній формі було запропоновано Г.І. Соколовим, який припустив наявність зв'язку репрезентованих на пекторалі образів з елевсінськими містеріями [Соколов 1997, с. 404]. 3 елевсінською тематикою узгоджуються також включені в композицію пекторалі маки (якщо правильна така атрибуція «коробочок», квітів і листя), які були створені богами під час блукань Деметри, щоб вона здобула спокій і відпочинок [Топоров 2011, с. 389-392]. При цьому можливий й інший, більш глибший міфологічний зв'язок «мак-Деметра», що міг виразитися, в тому числі, у використанні маку в якості одного з інгредієнтів ритуального напою, що забезпечував екстатичний стан учасникам містерій [Судник, Цивьян 1981, с. 308311]. Однак, як і в багатьох інших випадках, значення образу маку полісемантичне.

Можна обрати і інший напрямок в пошуках ймовірних тлумачень семантики пекторалі, виходячи 3 передбачуваного культу, служницею якого була жриця зі склепу 4. Одним 3 найбільш очевидних атрибутів, що визначають приналежність похованою жінки до жрецькому стану, є парадний головний убір - калаф. Калаф прикрашали 11 рельєфних фігурок - танцюючих менад і сатирів, а також менад на грифоні і барсі та фігурки крилатої Ніки (рис. 12: 1-11). Традиція декорування головних уборів фігурками танцюючих менад набула широкого поширення в IV ст. до н.е. в Північному Причорномор'ї. Відомо щонайменше 10 комплексів, де виявлені подібні аплікації, виконані в двох варіантах - на 

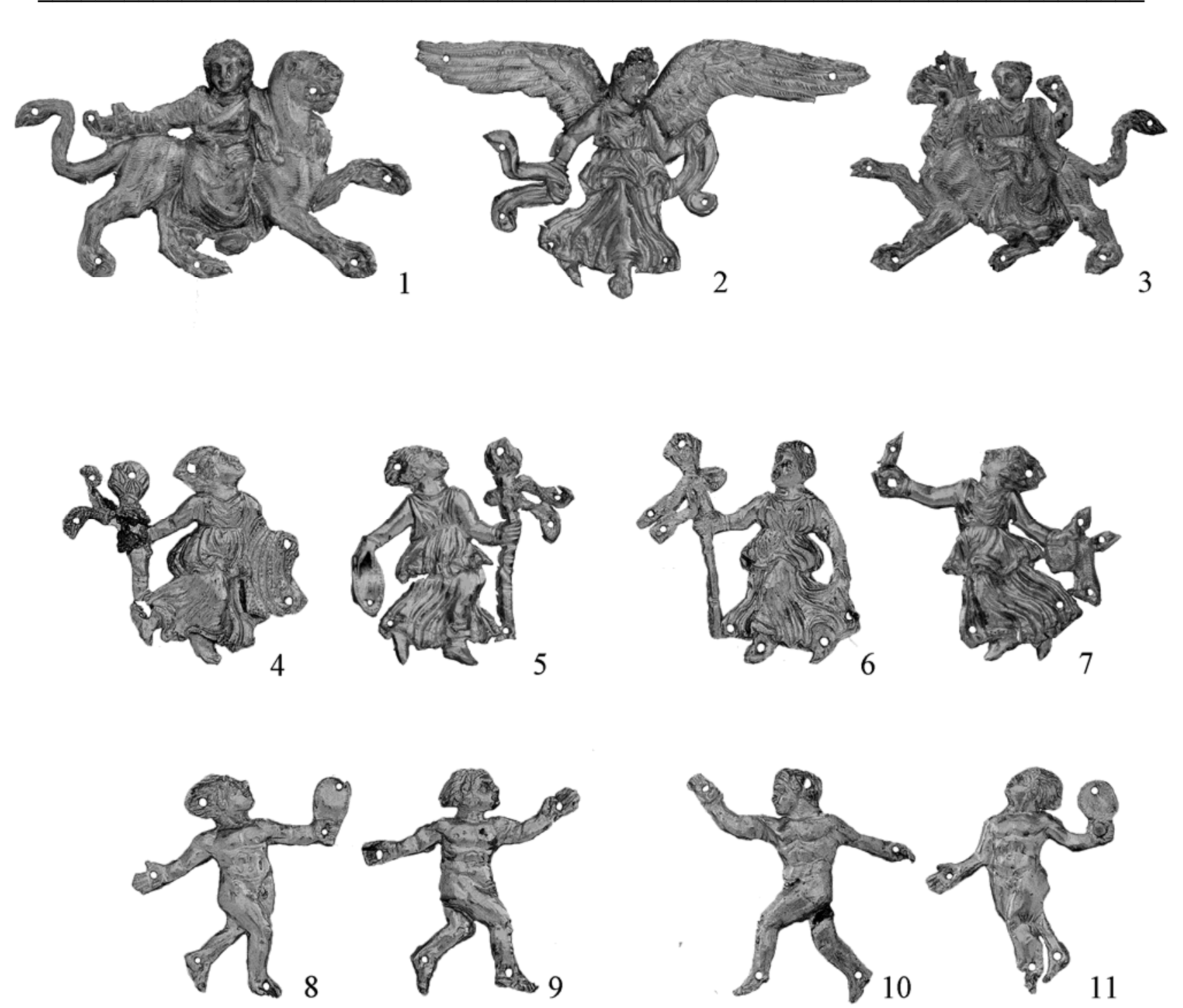

Рис. 12. Бляшки - прикраси головного убору зі склепу № 4 Великої Близниці (1-11)

[Калашник 2014, с. 180, 181]

Fig. 12. Plaques - headdress decoration from tomb № 4 the Velyka Blyznytsia

чотирикутних пластинах і у вигляді контурних бляшок ${ }^{25}$. Менади репрезентовані фігурками двох видів - 3 ножем і відрубаною цапиною ногою (1) і з тирсом, цапиною головою і плащем 3 цапиною шкури (2). Причини популярності цього сюжету у племен Північного Причорномор'я пояснюються по-різному і пов'язуються або з посиленням грецького впливу (i навіть цілеспрямованої пропагандою) на релігію скіфів, що і привело до запозичення скіфами еллінських культів [Рябова 1979; Русяєва 1995], або з використанням цих образів для втілення скіфами споконвічно своїх ритуалів [Раевский 1985; Бабенко 2002]. «Почет» Діоніса, що прикрашав головний убір жриці зі склепу 4 Великої Близниці репрезентований великою кількістю образів і вирізняється від «скіфських» менад стилістикою - на думку дослідників вони мають більш «грецький» вигляд [Шауб 2007, с. 341, 380; Бидзиля,

${ }^{25}$ Менади на пластинах виявлені в Великому Рижанівському кургані [Скорый, Хохоровски 2018, рис. 176: 2] та кургані 8 Пісочинського могильника [Бабенко 2005, рис. 17: 1-4, фото 11], у вигляді контурних аплікацій - у Діївому кургані [Piotrovsky and etc. 1986, pl. 135], Гаймановій Могилі [Бидзиля, Полин 2012, рис. 752: 1-6], Денисовій Могилі [Мозолевский 1980, рис. 68: 11], курганах 12 и 14 Рогачикського курганного поля [Болтрик, Фиалко 2007, рис. 1: 10, 11], кургані 6 біля с. Водославка [Купрій та ін. 2019, рис. 6: 2, 3]. 
Полин 2012, с. 494, 495]. Здається очевидним, що жриця, головний убір якої був прикрашений різноманітними персонажами діонісійского культу, мала до нього безпосереднє відношення. Якщо ж розглядати костюм небіжчиці в сукупності, то окремі його частини, більш того - ті, що займали домінуюче, найбільш видовищне положення - такі як головний убір і комплект нагрудних прикрас, повинні бути погоджені і взаємопов'язані між собою.

Як вже зазначалося вище, багато дослідників бачили в різних предметах інвентарю 3 цього поховання атрибути саме діонісійського культу. Це і ряд теракотових статуеток, i персонажі наборного намиста, і набір мініатюрного теракотового і бронзового посуду [Стефани 1871, с. 12, 17; Alexandrescu 1966, p.75, 76; Грач 1974, с. 36; Шауб 2007, с. 377; Соколов 1997, с. 403]. Тому висловлене Л.Е. Стефані припущення про зв'язок пекторалі («большого ожерелья») 3 «вакхічних культами» [Стефани 1871, с. 12] є цілком обгрунтованим і заслуговує більш пильної уваги.

Кількісно і композиційно домінантними персонажами пекторалі є цапи, репрезентовані сім'ю або дев'ятьма особинами, одна з яких розташована в центрі фризу. Цап був одним 3 найбільш поширених зооморфних втілень Діоніса, культовим символом цього бога. Саме в козеня (варіант: баранчика), рятуючись від гніву Гери, був перетворений Діоніс. Виражені цапині риси мають і персонажі діонісійського почету - Пан і сатири. Тому, можливо, в персонажах пекторалі ми бачимо втілення Діоніса в зооморфній інкарнації (цап у центрі) та його численної свити.

Зазначений вище можливий зв'язок між теракотовими статуетками і персонажами пекторалі в технологічному і стилістичному (гротескний, карикатурний стиль) плані можна доповнити ще одним аспектом, пов'язаним з театральною складовою. Частина теракотових статуеток 3 Великої Близниці дослідники трактують саме як образи комічних акторів давньогрецької комедії і сатиричної драми. Певні алюзії - видимі і ледь помітні - на ті чи інші сторони театрального життя можна побачити і в персонажах пекторалі з Великої Близниці. Обов'язковими учасниками сатиричної драми були обряджені в цапині шкури сатири. «Трагедія» $(\tau \rho \alpha \gamma \omega \delta i ́ \alpha)$ - «пісня цапів» як вид драми отримала назву від трагічного хору, учасники якого, зображуючи супутників Діоніса, одягалися в цапині шкури. Можна припустити, що об'єднані в п'ять сцен одинадцять фігурок цапів і баранів могли бути алегоричним зображенням учасників театрального дійства в зооморфному втіленні. Це враження посилює «олюднений» характер відтворених образів тварин, підкреслена їх емоційність і характерність поз у кожній з груп. Всі п'ять груп залишають відчуття деякої алюзії на конкретні сцени якоїсь п'єси, зрозумілі колу обізнаних.

Специфікою давньогрецького театру було використання акторами в постановках п'єс спеціальних масок - людських облич, голів тварин, міфологічних і фантастичних істот, покликаних передати особливості характеру і емоційного стану персонажа. Можливо, зазначені вище труднощі з визначенням виду двох тварин на пекторалі - то чи цапів, то чи баранів, також є певною алюзією на акторські маски, тобто, торевт відтворив двох баранів 3 одягненими масками цапів.

3 діонісійськими культами можуть бути пов'язані й інші образи, включені в композицію пекторалі з Великої Близниці. Відомі зображення зайця в сценах з Діонісом і персонажами його почету [Стефани 1863, с. 62-66; Хамула 2013, с. 190, 181]. Одним з атрибутів хтонічного Діоніса - Загрея, були вінки з головок маку [Судник, Цивьян 1981, с. 311].

Безперечно, що викладені вище спостереження і припущення носять певною мірою гіпотетичний характер. Але видається очевидним, що в пошуках вирішення проблем семантики образів і сюжетів пекторалі з Великої Близниці слід виходити не з досить хитких паралелей з композицією пекторалі з Товстої Могили, незважаючи на зовнішню схожість обох прикрас. Більш перспективним для розуміння змісту композиції Таманської пекторалі $\epsilon$ іiі узгодження з семантикою різних предметів культу з цього поховання і імовірних жрецьких функцій небіжчиці в цілому. 
Поховальний контекст і функції пекторалей. Такі ж разючі відмінності можна побачити, аналізуючи особливості соціального стану похованих, поховального контексту і ймовірних функцій прикрас. Курган Товста Могила належить до поховань вищої кочової аристократії, хоча і не корелюється з імовірними могилами безпосередньо скіфських царів IV ст. до н.е. За параметрами насипу Б.М. Мозолевський відносив Товсту Могилу до третьої групи курганів скіфської знаті [Мозолевський 1979, с. 152; Тереножкин, Мозолевский 1988, c. 151]. У моделі соціальної піраміди Скіфії другої половини IV ст. до н.е., побудованої Ю.В. Болтриком за трудовитратами на зведення поховальних споруд і набором інсигній, поховані в Товстій Могилі займають третю сходинку (після царів і членів царських сімей), репрезентовану родичами царя [Болтрик 1994, с. 85-90]. Незвичайне розташування пекторалі і деяких інших статусних предметів - на підлозі дромоса, поза межами похоронної камери генерувало виникнення ще однієї проблеми, пов'язаної зі спробами пояснити причини цього явища. Запропоновані тлумачення вирізняються різноманітністю. Д.О. Мачинский у залишених в дромосі предметах бачив сліди ритуальних дій, що включали обряд жертвопринесення і були пов'язані з культом Ареса і Артеміди [Мачинский 1978, с. 146-148]. Б.М. Мозолевський комплекс дорогоцінних знахідок на дні дромоса відносив до предметів культу, відокремлених від решти інвентарю і 3 цієї причини прихованих в схованці [Мозолевський 1979, с. 159; Тереножкин, Мозолевский 1988, с. 171-175]. М.В. Степанов, навпаки, розглядаючи центральне поховання Товстої Могили як одне з поховань змієборця, пояснював збереження предметів в дромосі відсутністю до них інтересу грабіжників, так як, не «побувавши в світі мертвих», вони не набули магічних властивостей [Степанов 2015, c. 47]. В.Ю. Михайлин знахідку пекторалі в дромосі пояснював іiї приналежністю не до поховального інвентарю, а до предметів, пов'язаних 3 поминальною тризною, що проводилася через рік після похорон [Михайлин 2005, с. 174, 175]. Також розташування пекторалі в дромосі пояснювалося ऑіi «неканонічністю» [Бабенко 2018б, с. 200] або приналежністю до військових трофеїв, недбало кинутих біля входу в камеру [Гребенников, Смирнов 2018, с. 121]. Одним 3 найбільш вдалих тлумачень є гіпотеза О. П. Мошинського. Дослідник, відштовхуючись від явного дисонансу між багатством поховального інвентарю Товстої Могили та відносно скромними розмірами курганного насипу, що явно поступається «царській четвірці» кінця V-IV ст. до н.е.; датування поховання, що передує часу спорудження Чортомлика-Огузу-Олександрополя; а також значення пекторалі як символу царської влади, вважав, що пектораль могла належати спадкоємцю Атея, який ще не мав права на носіння символу царської гідності і передчасно помер [Мошинский 2002, с. 87]. Подібне трактування добре узгоджується і з імовірними функціями пекторалі. 3 одного боку пектораль, як варіант ускладненою гривни [Бабенко 2018б], була традиційним для скіфської культури маркером високого соціального статусу iї власника. Але, швидше за все, іiі функції були трохи ширше. Як зазначалося вище, багато дослідників центральну сцену верхнього фризу пов'язують 3 культом хварна/фарна, вважаючи саму пектораль своєрідним його матеріальним втіленням. Тому пектораль могла мати функції церемоніального атрибуту, що використовувався під час ініціаціонно-інвеститурного акту обрання царя і набуттям ним хварна/фарна - тобто обряду, ключові моменти якого були відтворені в сюжетах самої пекторалі [Бабенко 2013, с. 118-120].

Велика Близниця була усипальницею шляхетної родини - грецької або еллінізованої синдської, представники якої виконували жрецькі функції в різних культах ${ }^{26}$. По суті, всі

${ }^{26}$ Останнім часом неодноразово піддавалася сумніву жрецька атрибуція власниці пекторалі. Так, В.Ю. Михайлин сцену переслідування зайця собакою на пекторалі з Великої Близниці трактував як символ першого балца - статусного полювання, що складало початковий етап військової ініціації. 3 цієї причини дослідник вважав, що в кургані був похований не «дорослий скіфський цар», а «принц», який навічно залишився на першій стадії військової ініціації [Михайлин 2005, с. 80], що зовсім не узгоджується з етнічним контекстом і статевою приналежністю небіжчиці. Заперечення 
предмети інвентарю з гробниці 4 «третьої дами» в тій чи іншій мірі відображають жрецьку діяльність небіжчиці. Вони «связаны между собой по содержанию и объединены какой-то единой идеей, ... специально, с определенной тенденцией подобраны, исходя из общественного положения умершего, его мировоззрения...» [Передольская 1962, с. 52]. В костюмі небіжчиці пектораль була вписана в контекст комплексу прикрас, насамперед набору 3 трьох намист - двох набраних і власне «пекторалі», а також головного убору, декорованого фігурками персонажів діонісійського почту. Якщо прикрасу з Товстої Могили справедливо розглядати як гривну, трансформовану в «пектораль» [Бабенко 2018б], то прикраса з Великої Близниці, безсумнівно, варіант саме намиста, але виконаного також в іншій традиції при спробі наслідування пекторалі з Товстої Могили. Термінологічне протиставлення прикрас - нагрудник (з Товстої Могили) і намисто (рос. «ожерелье») (3 Великої Близниці), що використовується в низці робіт А.П. Манцевич [Манцевич 1976; 1980], і на думку Н.О. Гаврилюк підкреслює різні їх функції [Гаврилюк 2016, с. 284], видається цілком обгрунтованим. Тому пектораль з Великої Близниці та наявні в їі декорі образи і сюжети слід розглядати в безпосередньому зв'язку з жрецькими функціями похованою.

Проблема авторства двох пекторалей. Вищевикладене дозволяє більш обгрунтовано підійти до вирішення питання про авторство двох пекторалей. Прикраси неодноразово зіставлялися і серед дослідників домінує точка зору про створення обох пекторалей або одним майстром [Уильямс, Огден 1995, с. 127; Русяєва 2008, с. 523; Полин 2014, с. 486], або ювелірами однієї майстерні [Piotrovsky 1975, p. 21; Алексеев 1987, с. 29, 30; Рудольф 1993, c. 88; Jacobson 1995, p. 119; Williams 1998, p. 103; Савостина 1999, с. 201; Themelis 2003, p. 165]. Точка зору на цю проблему М.Ю. Трейстера неоднозначна. Дослідник відзначає одночасну близькість філігранного мотиву на «комірах» пекторалі 3 Товстої Могили 3 декором гривни з Куль-Оби («майстер гривни зі скіфськими вершниками»), а репертуару тварин - з продукцією «майстерні обкладок горитів і піхов мечів». Подібне поєднання, на думку М.Ю. Трейстер, свідчить або про тісну співпрацю обох майстерень, або про їх злиття до середини IV ст. до н.е. [Treister 2005, p. 60, 62]. Пектораль з Великої Близниці згадана серед решти виробів однойменної «майстерні Великої Близниці» [Treister 2005, p. 60, 61]. Але в іншому місці, заперечуючи проти початкової точки зору Д. Вільямса і Д. Огдена про можливе єдине авторство обох пекторалей, підтримує думку В. Рудольфа щодо приналежності прикрас до виробів одного кола (за В. Рудольфу, «Чортомлицької майстерні») [Treister 2005, p. 62, 63]. Також на думку М.Ю. Трейстера, виходячи 3 передбачуваного А. Шварцмайєр хронологічного розриву між двома пекторалями (20-ті роки IV ст. до н.е. для прикраси 3 Товстої Могили та початок III ст. до н.е. для пекторалі з Великої Близниці), дослідниця вважала їх продукцією різних майстерень [Трейстер 2010, с. 555, 589, прим. 229]. Слід все ж зазначити, що, незважаючи на постійний акцент на несхожість обох пекторалей, проблема майстерень А. Шварцмайєр у статті не порушувалася [Schwarzmaier 1996, S. 127129]. Хронологічний же розрив, що перевищав трохи два десятиріччя (хоч і явно завищених абсолютних дат), навряд чи можна вважати недосяжним навіть для робіт одного майстра, тим більш майстерні.

Для точнішої кореляції двох пекторалей принципове значення має встановлення часу їх виготовлення. Ці дати визначають два чинники - безпосередньо час поховання i термін використання пекторалей до їх покладання в могилу. Запропоновані для Товстої Могили дати вписуються в діапазон другої-третьої чверті IV ст. до н.е. Це середина - початок третьої чверті IV ст. до н.е. [Мозолевський 1979, с. 229; Мозолевский, Полин 2005, с. 362-364], 350320 рр. до н.е. [Алексеев 2003, с. 263, 264], друга чверть IV ст. до н.е., не пізніше 350 р. до н.е. [Бидзиля, Полин 2012, с. 521-523; Полин 2014, с. 273-279]. Хронологія комплексів

щодо жрецьких функцій похованих у Великій Близниці, висловлені в низці робіт А. Шварцмайер [Schwarzmaier 1996; 2006], були переконливо спростовані I. Ю. Шаубом [Шауб 2015, с. 214-222]. 
Великої Близниці складніша. Відсутня єдина думка щодо послідовності поховань [Ростовцев 1914, с. 10-20; Пругло 1974, с. 64, 65; Полин 2014, с. 485]. Внаслідок цього у відносній хронологічній колонці поховання з гробниці 4 могло обіймати як найбільш ранню [Передольская 1962, с. 48, 49], так і саму пізню позицію [Minss 1913, p. 423-429; Züchner 1942, S. 30; Schwarzmaier 1996, S. 136], розміщатися посередині [Полин 2014, с. 484487] або мати широку дату [Стефани 1871 , с. 6]. В абсолютному значенні діапазон запропонованих для гробниці 4 дат широкий - від другої чверті IV ст. до н.е. [Передольская 1962, с. 48, 49] до перших десятиліть III ст. до н.е. [Ростовцев 1914, с. 10-20], кінця IV ст. або рубежу IV-III ст. до н.е. [Пругло 1974, с. 77], початку III ст. до н.е. [Pfrommer 1990, S. 273-274; Schwarzmaier 1996, S. 128]. С.В. Полін встановив для цього поховання дату в межах третьої чверті IV ст. до н.е., але при цьому вважав, обидві пекторалі були виготовлені одним майстром синхронно, на початку другої чверті IV ст. до н.е. [Полин 2014, с. 486].

Про тривалість проміжку часу між виготовленням пекторалей та їх розміщенням у могилах можна говорити лише гіпотетично. Стосовно пекторалі з Товстої Могили існують діаметрально протилежні думки. Виходячи з наявності значних «прижиттєвих» ушкоджень [Мозолевський 1979, с. 73, 83, 86], В. Рудольф прийшов до висновку про тривалість терміну використання пекторалі і, навіть, «участі» іï в битвах [Рудольф 1993, с. 85]. Напроти, В.Ю. Михайлин припускав виготовлення пекторалі спеціально з нагоди річної поминальної тризни [Михайлин 2005, с. 175]. Це малоймовірно не тільки через кількість вже зазначених ушкоджень, які малоймовірно було отримати в такий незначний термін (з урахуванням часу, витраченого на виготовлення настільки трудомісткого виробу), але, перш за все, сліди іiі прижиттєвого ремонту. Можливо, це той випадок, де істину слід шукати десь посередині двох полярних думок. Швидкому пошкодженню пекторалі міг сприяти і неспокійний, кочовий і військовий побут їі власника.

Прижиттєві пошкодження пекторалі з Великої Близниці візуально більш масштабні. Це може бути наслідком тривалішого терміну ï використання, хоча навряд чи коректно визначати його так прямолінійно. Водночас, якщо розглядати дану пектораль як предмет особистої прикраси, то визначений дослідниками на основі аналізу кісткових решток (зубів) та інвентарю молодий або дуже молодий вік похованої в гробниці 4 жінки [Строганов 1869, c. VI-VIII; Соколов 1997, с. 400, 401] може свідчити саме про зворотне - порівняно малий період їі використання, а, відповідно, й незначний термін між виготовленням пекторалі та розміщенням її в могилі.

В цілому, хоча існує певна невизначеність у датуванні поховань i термінах прижиттєвого використання пекторалей, можна досить впевнено говорити як про суміжність обох пекторалей в часі, так і про їх хронологічну послідовність, причому виготовлення пекторалі з Товстої Могили, безсумнівно, передувало таманській пекторалі. Тому навряд чи можна погодиться 3 думкою М.В. Русяєвої, яка стверджувала зворотну послідовність виготовлення пекторалей та вважала пектораль 3 Великої Близниці продукцією ще недосвідченого майстра, який згодом, освоївши тонкощі техніки ювелірного мистецтва, удосконаливши майстерність, а також вивчивши звички і анатомію тварин, зміг створити видатніший шедевр [Русяєва 2008, с. 523]. Подібному твердження суперечить не тільки хронологія комплексів. Його хибність доводиться і сумнівністю картини еволюції створення шедевра, основи композиції якого були закладені у ще незрілому виробі, і потім, з роками, за допомогою творчої трансформації цілого ряду запозичень, відтворені знову ще в одній пекторалі. Більш очевидний і прийнятний зворотній зв'язок - створення шедевру і спроба залучення втілених в ньому композиційних і стилістичних знахідок при виготовленні нової прикраси.

Висновки. Отже, грунтуючись на аналізі конструктивних особливостей обох пекторалей, технічних прийомів, використаних при їх виготовленні, нюансів стилістики та семантики прикрас, а також неоднаковому рівні майстерності торевтів, можна припустити 
різне їх авторство. Задум пекторалі з Товстої Могили грунтувався на широкій ерудиції майстра, знайомого з видатними творами мистецтва і здатного творчо переробити ідеї, втіливши їх у своєму творінні, в образах і сюжетах якого традиційні мотиви та інновації переплетені дуже органічно. Високому художньому рівню пекторалі відповідає і найвища майстерність технічного виконання. Можна не сумніватися, що у колег по ювелірній справі, до передачі прикраси замовнику, пектораль отримала широку популярність і високу оцінку. Беручи до уваги існування серед ювелірів практики виготовлення виробів за певним зразком ${ }^{27}$, можна припустити, що подібною моделлю для наслідування могла стати i пектораль з Товстої Могили. При цьому торевт, що виготовив пектораль з Великої Близниці, здійснив не повне, а часткове копіювання зразка. Були відтворені загальна форма прикраси у вигляді півмісяця 3 фігурним ажурним фризом, обрамленим крученими джгутами, прикріплені на шарнірах застібки, периферійні сюжетні сцени (гонитва зайця собакою). Показово, що саме ці елементи, в яких найбільш виразно простежується запозичення, вирізняються невисоким художнім і технічним рівнем. Причому при виготовленні джгутів була використана зовсім інша конструкція, що, ймовірно, не зовсім підходила для подібного виробу. Це може свідчити про те, що певна частина професійних технологічних секретів виявилася торевту невідомою. Відповідно, якщо окремі нюанси технічних прийомів одного майстра були недоступні іншому, то, найімовірніше, і працювали вони в різних майстернях. Непрямим підтвердженням цього висновку може бути своєрідність деяких ювелірних прикрас з поховань Великої Близниці. Вони помітно вирізняються серед виробів боспорських торевтів, що масово надходили скіфським замовникам. У якості прикладу можна навести добре відомий калаф з гробниці 1, прикрашений сценами битви арімаспів чи амазонок з грифонами, що вирізняється конструкцією і репрезентованими сюжетами серед головних уборів скіфських поховань. Те ж саме можна сказати і про бляшки з зображенням танцюючих менад, добре відомих у скіфських похованнях ${ }^{28}$, але репрезентованих у Великої Близниці в зовсім інший іконографії. Стилістичну своєрідність прикрас з Великої Близниці відзначали й інші дослідники. Д. Вільямс протиставляв вироби «Левового Майстра» (ряд прикрас із Солохи, Куль-Оби, Чортомлика та інших пам'яток, в тому числі й пектораль 3 Товстої Могили) продукції «Майстра Великої Близниці», щоправда, вважаючи при цьому наявність зв'язку між ювелірами - як вчителя і учня або, навіть, батька і сина [Williams 1998, p 99-104.]. М.Ю. Трейстер також відніс до окремої групи вироби «Майстерні Великої Близниці», згадавши і пектораль [Treister 2005, p. 60, 61]. Отже, складається враження, що представники шляхетної боспорської родини, які залишили поховання Великої Близниці, користувалися послугами «персональної» ювелірної майстерні, продукція якої відрізнялася від виробів ювелірів, котрі задовольняли попит безпосередньо скіфських замовників.

Таким чином, зв'язок між двома пекторалями - з Товстої Могили та Великої Близниці видається очевидним, але для розуміння його характеру вирішальне значення мають принципові відмінності в конструкції і технічних прийомах, використаних торевтами при їх виготовленні. Це може свідчити про те, що пекторалі були створені не тільки різними ювелірами, а й представниками різних майстерень. Подібність двох пекторалей пов'язана 3

${ }^{27}$ Найбільш виразно подібна практика виявляється в широкому запозиченні торевтами при виготовленні як аплікацій, так і інших виробів, різноманітних монетних сюжетів [Толстой, Кондаков 1889, с. 113; Ростовцев 1925, с. 443-449; Манцевич 1949; Шелов 1956, с. 140; Онайко 1970, с. 46-49; Алексеев 1987, с. 32-38; Королькова 1998; Мозолевский Полин, 2005, с. 392-410; Трейстер 2005, с. 504; Болтрик та ін. 2009, с. 46; Полин 2016; Бабенко 2017; та багато інших]. Моделлю для виготовлення бляшок зі зображенням танцюючих менад могла слугувати об'ємна скульптура [Круглов 2004, с. 36, 37]. Дуже наочний приклад виготовлення за якіснішим зразком менш художніх копій демонструють прикрашені рослинним орнаментом пластини й метопіди головних уборів 3 Чортомлика, Товстої Могили, курганів № 8 групи «П'ять братів» Слизаветівського могильника і № 8 Пісочинського могильника (див. прим. 13).

28 Див. прим. 25. 
використанням торевтом при виготовленні прикраси для жриці, похованою у Великій Близниці, у якості зразка-моделі пекторалі з Товстої Могили. Ряд конструктивних i композиційних запозичень визначили візуальну схожість пекторалей, але семантика репрезентованих на прикрасах сюжетів, а також можливі їх функції, не тотожні. Пектораль 3 Товстої Могили є своєрідною ускладненою модифікацією гривни, що була у скіфів однією 3 найбільш наочних інсигній високого соціального статусу власника. Прикраса використовувалася під час інвеститурного акту і ключові моменти цього обряду, такі як набуття хварну/фарну новообраним царем, і були відтворені в репрезентованих сценах. Пектораль 3 Великої Близниці входила до складу прикрас представниці шляхетної боспорської родини, яка виконувала жрецькі функції в різних культах, перш за все, діонісійського i, ширше, елевсінського кола. Саме з цими функціями слід пов'язувати наявні на прикрасах жриці образи і сюжети.

Бабенко Л.И.

\section{ДВЕ ПЕКТОРАЛИ - ШЕДЕВР И ЕГО РЕПЛИКА}

Тождество формы, общей структуры композиции, отдельных элементов конструкции, а также некоторых образов и сюжетов пекторалей из Толстой Могилы и Большой Близницы способствовали распространению мнения об их изготовлении одним мастером или торевтами из одной мастерской. Однако более тщательное сравнение обоих украшений позволяет сделать иные выводы. Обе пекторали имеют разную конструкцию жгутов, а также систему обеспечения жесткости изделий в целом. Большинство изображенных на таманской пекторали животных выполнены в оригинальной «гротескной» стилистике, не свойственной изделиям боспорских торевтов. Представленные на обеих пекторалям образы и образованные ими сюжеты отличаются семантикой, а, следовательно, - и функциональным назначением украшений. Таким образом, несмотря на внешнее сходство, пекторали были созданы не только различными ювелирами, но и представителями различных мастерских.

Ключевые слова: пектораль, Толстая Могила, Большая Близница, скифы, торевтика, гротеск, Дионис, элевсинские мистерии.

BabenkoL.I.

\section{TWO PECTORALS - A MASTERPIECE AND ITS REPLICA}

The shape sameness, general structure of composition and separate elements of the construction, as well as several images and plots of the pectorals from the Tovsta Mohyla and Velyka Blyznytsia promoted for spreading the opinion about their manufacturing by the same master or by the toreuts from the same workshop. However more profound comparison of the two jewels allows making other conclusion. Both pectorals have different construction of twists and different system for promoting stiffness on the whole. The greater part of the animals depicted on the Taman pectoral are formed in the original grotesque stylistics, which is not peculiar to handiwork of the Bosporan toreuts. The images depicted on the both pectorals and the plots formed by them differ in semantics, and therefore differ in the jewels purpose of use. Hence, despite the physical resemblance, the pectorals were manufactured not only by different jewelers, but also by representatives of different workshops.

Keywords: pectoral, Tovsta Mohyla, Velyka Blyznytsia, Scythians, toreutics, grotesque, Dionysus, Eleusinian Mysteries.

\section{СПИСОК ДЖЕРЕЛ І ЛІТЕРАТУРИ}

Алексеев А.Ю. Заметки по хронологии скифских степных древностей IV в. до н.э./ А.Ю. Алексеев // СА. - 1987. - № 3. - С. 28-39.

Алексеев А.Ю. Хронография Европейской Скифии VII-IV веков до н.э. / А.Ю. Алексеев.СПб.: Изд-во Гос. Эрмитажа, 2003. - 416 с. 
Алексеев А.Ю. Золото скифских царей из собрания Эрмитажа / А.Ю. Алексеев. - СПб.: Изд-во Гос. Эрмитажа, 2012. - 272 с.

Алексеев А.Ю. Чертомлык. Скифский царский курган IV в. до н.э. / А.Ю. Алексеев, В.Ю. Мурзин, Р. Ролле. - К.: Наукова думка, 1991. - 413 с.

Артамонов М.И. Сокровища скифских курганов в собрании Государственного Эрмитажа / М.И. Артамонов. - Прага: Артия; Л.: Советский художник, 1966. - 120 с.+331 табл.

Бабенко Л.И. Песочинский курганный могильник скифского времени / Л.И. Бабенко. Харьков: ИД Райдер, 2005. - 284 с.

Бабенко Л.И. Пан и сюжет пекторали - неслучайные совпадения? / Л.И. Бабенко // АДІУ. 2016. - Вип. 2 (19). - С. 9-26.

Бабенко Л.И. Два монетных сюжета на изделиях греко-скифской торевтики / Л.И. Бабенко // АДІУ. - 2017. - Вип. 2 (23). - С. 30-39.

Бабенко Л.И. Шарнирные петли пекторали из Толстой Могилы / Л.И. Бабенко // Музейні читання. Матеріали наукової конференції «Ювелірне мистецтво - погляд крізь віки». (м. Київ, Музей історичних коштовностей України, 21-22 листопада 2016 р.). - К.: ТОВ «Фенікс», 2017а. - С. 37-47.

Бабенко Л.И. Конструкция и техника изготовления жгута гривны из Куль-Обы / Л.И. Бабенко // Музейні читання. Матеріали наукової конференції «Ювелірне мистецтво - погляд крізь віки». (м. Київ, Музей історичних коштовностей України, 21-22 листопада 2017 р.). - К.: ТОВ «Фенікс», 2018. - С. 30-47.

Бабенко Л.И. О бордюрах пекторалей из Толстой Могилы и Большой Близницы / Л.И. Бабенко // АДІУ. - 2018а. - Вип. 2 (27). - С. 155-163.

Бабенко Л.И. Пектораль или гривна? (о соответствии термина и морфологии украшения) / Л.И. Бабенко // Stratum plus. - 2018б. - № 3. - С. 187-204.

Бабенко Л.И. Витые и ложновитые шейные украшения из мастерских боспорских торевтов / Л.И. Бабенко // АДІУ. - 2019. - Вип. 2(31). - С. 493-505.

Бабенко Л.І. Жіночий головний убір IV ст. до н.е. 3 кургану 8 біля с. Пісочин Харківської області / Л.І. Бабенко // Археологія. - 2002. - № 4. - С. 59-69.

Бабенко Л.І. До семантики центральної сцени пекторалі з Товстої Могили / Л.І. Бабенко // Древности 2013: Харьковский историко-археологический ежегодник. - Харьков: Харьковское историко-археологическое общество; ООО «НТМТ», 2013. - С. 111-122.

Бессонова С.С. Религиозные представления скифов / С.С. Бессонова. - К.: Наукова думка, 1983. $-138 \mathrm{c}$.

Бидзиля В.И. Скифский царский курган Гайманова Могила / В.И. Бидзиля, С.В. Полин. - К.: Издательский дом «Скиф», 2012. - 752 с.

Болтрик Ю.В. Социальная структура Скифии IV в. до Р.Х., отраженная в погребальных пам'ятниках // Kimmerowe, Scytowie, Sarmaci. Księga poświęcona pamięci profesora Tadeusza Sulimirskego. - Krakow: Księgarnia Akademicka, 2004. - S. 85-91.

Болтрик Ю.В. Украшения из скифских погребальных комплексов Рогачикского курганного поля / Ю.В. Болтрик, Е.Е. Фиалко // ССПК. - 2007. - Т. XIV. - С. 51-93.

Болтрик Ю.В. Імпортний бронзовий посуд із східної могили Бердянського кургану / [Ю.В. Болтрик, М.Ю. Трейстер , О.Є. Фіалко] // Археологія. - 2009. - № 1. - С. 40-52.

Венедиков И. Тракийското изкуство / И. Венедиков, Т. Герасимов. - София: Бьлгарски художник, 1973. -408 с.

Вертієнко Г.В. Іконографія скіфської есхатології / Г.В. Вертієнко. - К.: Інститут сходознавства ім. А.Ю. Кримського НАН України, Видавець Олег Філюк, 2015. - 224 с.

Гаврилюк Н.А. История экономики Степной Скифии VI-III вв. до н.э. / Н.А. Гаврилюк. - К.: Изд-во ПТФ, 1999. - 424 с.

Гаврилюк Н.А. Пектораль из Толстой Могилы как источник для изучения экономики Степной Скифии. Историография вопроса / Н.А. Гаврилюк // АДІУ. - 2016. - Вип. 2 (19). - С. 284-291.

Гаврилюк Н.А. Пектораль из Толстой Могилы как объект и средство невербальной коммуникации / Н.А. Гаврилюк, Н.П. Тимченко // ТГЭ. - 2015. - [T.] LXXVII: Археология без границ: коллекции, проблемы, исследования, гипотезы. - С. 97-126.

Гайдукевич В.Ф. Боспорское царство / В.Ф. Гайдукевич. - М.-Л.: Изд-во АН СССР, 1949. $624 \mathrm{c}$. 
Грач Н.Л. Терракотовые статуэтки из кургана Большая Близница / Н.Л. Грач // САИ. - М.: Наука, 1974. - Вып. Г1-11. - Ч. IV: Терракотовые статуэтки. Придонье и Таманский полуостров. C. 36-39.

Гребнев Я.В. К вопросу об истории отечественного козоводства / Я.В. Гребнев // Князь С.П. Урусов. Книга о козе / редакт. и совр. коммент. Я.В. Гребнева. - К.: ННЦ Институт аграрной экономики, 2007. - С. 288-304.

Гребенников Ю. История населения Степного Побужья в VI-V ст. до н.э. / Ю. Гребенников, Л. Смирнов // Forum Olbicum II. Пам'яті В.В. Крапівіної (до 150-річчя дослідження Ольвії): Матеріали міжнародної археологічної конференції (4-6 травня 2018 р.). - Миколаїв: Лукомор'є, 2018. - C. 120-121.

Древности Боспора Киммерийского, хранящиеся в императорском музее Эрмитажа. - СПб., 1854. - T. I. - CLIV+279 c.

Калашник Ю.П. Греческое золото в собрании Эрмитажа: Памятники античного ювелирного искусства из Северного Причерноморья / Ю.П. Калашник. - СПб.: Изд-во Гос. Эрмитажа, 2014. - 280 с.

Королькова Е.Ф. Иконография образа хищной птицы в скифском зверином стиле VI-IV вв. до н.э. / Е.Ф. Королькова // Проблемы археологии. - СПб., 1998. - Вып. 4. - С. 166-177.

Круглов А.В. Реконструкция эллинистической скульптурной группы «Рождение Диониса из бедра Зевса» / А.В. Круглов // Эллинистические штудии в Эрмитаже. К шестидесятилетию Михаила Борисовича Пиотровского. - СПб.: Изд-во Гос. Эрмитажа, 2004. - С. 34-43.

Кузьмина Е.Е. Опыт интерпретации некоторых памятников скифского искусства / Е.Е. Кузьмина // ВДИ. - 1984. - № 1. - С. 93-108.

Кузьмина Е.Е. Сюжет борьбы хищника и копытного в искусстве «звериного» стиля евразийских степей скифской эпохи / Е.Е. Кузьмина // Скифо-сибирский мир. Искусство и идеология. - Новосибирск: Наука, 1987. - С. 3-12.

Купрій С.О. Курган 6 могильника Водославка: поховання скіфської знаті / С.О. Купрій, О.В. Ліфантій, О.В. Шелехань // АДІУ. - 2019. - Вип. 4 (33). - С. 182-212.

Кучма Л.Д. Украина - не Россия / Л.Д. Кучма. - М.: Время, 2003. - 560 с.

Манцевич А.П. К вопросу о торевтике в скифскую эпоху / А.П. Манцевич // ВДИ. - 1949. № 2. - C. 196-220.

Манцевич А.П. Чертомлыкская ваза и пектораль из Толстой Могилы / А.П. Манцевич // Pulpudeva. - Sofia, 1974. - Vol. I. - C. 83-98.

Манцевич А.П. Золотой нагрудник из Толстой Могилы / А.П. Манцевич // Thracia Serdicae. 1980. - Vol. V. - C. 97-120.

Манцевич А.П. Курган Солоха. Публикация одной коллекции / А.П. Манцевич. - Л.: Искусство, 1987. - 143 с.

Мачинский Д.А. Пектораль из Толстой Могилы и великие женские божества Скифии / Д.А. Мачинский // Культура Востока: Древность и раннее средневековье. - Л.: Аврора, 1978. - С. 131-150.

Михайлин В. Тропа звериных слов: Пространственно-ориентированные культурные коды в индоевропейской традиции / В. Михайлин. - М.: Новое литературное обозрение, 2005. - 528 с.

Мозолевский Б.Н. Курган Толстая Могила близ г. Орджоникидзе на Украине / Б.Н. Мозолевский // СА. - 1972. - № 3. - С. 268-308.

Мозолевский Б.Н. Скифские курганы в окрестностях г. Орджоникидзе на Днепропетровщине (раскопки 1972-1975 гг.) / Б.Н. Мозолевский // Скифия и Кавказ. - К.: Наукова думка, 1980. - С. 70-154.

Мозолевский Б.Н. Курганы скифского Герроса IV в. до н.э. (Бабина, Водяна и Соболева могилы) / Б.Н. Мозолевский, С.В. Полин. - К.: Издательский дом «Стилос», 2005. - 600 с. + 24 табл. цв.илл.

Мозолевський Б. Синтез скіфо-античної думки. До інтерпретації пекторалі з Товстої Могили / Б. Мозолевський // Всесвіт. - 1978. - № 2. - С. 191-204.

Мозолевський Б.М. Товста Могила / Б.М. Мозолевський. - К.: Наукова думка, 1979. - 251 с.

Молева Н.В. Тандем «заяц - собака» в религиозном мировоззрении древних греков / Н.В. Молева // Артефакты и сакральное в истории Боспора. - Нижний Новгород: Изд-во ННГУ, 2017. - C. 79-91.

Мошинский А.П. Пектораль из Толстой Могилы как символ царской власти / А.П. Мошинский // ДА. - 2002. - № 1-2. - С. 84-88.

Мурзин В.Ю. Бердянский курган (погребальный комплекс скифского аристократа IV в. до н.э.) / [В.Ю. Мурзин, Ю.А. Белан, Е.П. Подвысоцкая]. - К.: Видавець Олег Філюк, 2017. - 136 с. 
Никольская К.Д. О странном наследстве в III книге «Артхашастры» Каутильи / К.Д. Никольская // Stratum plus. - 2005-2009. - № 3: Скифские интерпретации. - С. 371-376.

ОАК за 1869 год: с атласом. - СПб., 1871. - XXII+256 c.+VI табл.

Онайко Н.А. Античный импорт в Приднесторовье и Побужье в IV-II вв. до н.э. / Н.А. Онайко // САИ. - 1970. - Вып. Д1-27. - 212 с.

Передольская А.А. О сюжетах трех терракотовых статуэток, найденных в кургане Большая Близница / А.А. Передольская // СА. - 1950. - Т. ХІІІ. - С. 255-271.

Передольская А.А. К вопросу о терракотах из кургана Большая Близница / А.А. Передольская // CA. - 1955. - T. XXIV. - C. 54-73.

Передольская А.А. Терракоты из кургана Большая Близница и Гомеровский гимн Деметре / А.А. Передольская // ТГЭ. - 1962. - Т. VII. - С. 46-93.

Петренко В.Г. Украшения Скифии VII-III вв. до н.э. / В.Г. Петренко // САИ. - М.: Наука, 1978. - Вып. Д4-5. - 144 с.

Петрухин В.Я. «Золотое руно» и «скифская космограмма» / В.Я. Петрухин // МИФ-7:

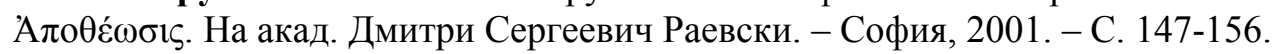

Підвисоцька О.П. Технологічні спостереження над середнім ярусом пекторалі із Товстої Могили / О.П. Підвисоцька, І.Т. Черняков // Музейні читання. Матеріали наукової конференції. Грудень 2001 р. - К.: Музей історичних коштовностей України, 2002. - С. 17-26.

Полидович Ю.Б. Пектораль - символ жизни и смерти / Ю.Б. Полидович // Журнал о металле. 2006. - № 3-4 (9). - С. 82-85.

Полидович Ю.Б. Боспорские терракотовые статуэтки со сценой охоты на зайца / Ю.Б. Полидович // БФ: сакральный смысл региона, памятников, находок: Материалы Международной научной конференции. Ч. І. - СПб., 2007. - С. 93-99.

Полидович Ю.Б. Образ зайца в скифском искусстве / Ю.Б. Полидович, Г.Н. Вольная // Древности Евразии от ранней бронзы до раннего средневековья. Памяти В.С. Ольховского. - М.: ИА PAH, 2005. - C. 425-436.

Полин С.В. Скифский Золотобалковский курганный могильник V-IV вв. до н.э. на Херсонщине / С.В. Полин. - К.: Издатель Олег Филюк, 2014. - 776 с.

Пругло В.И. К вопросу о дате кургана Большая Близница / В.И. Пругло // СА. - 1974. - № 3. - С. 64-77.

Раевский Д.С. Из области скифской космологии (Опыт семантической интерпретации пекторали из Толстой Могилы) / Д.С. Раевский // ВДИ. - 1978. - № 3. - С. 115-133.

Раевский Д.С. Модель мира скифской культуры. Проблемы мировоззрения ираноязычных народов евразийских степей I тысячелетия до н.э. / Д.С. Раевский. - М.: Наука, 1985. - 256 с.

Розанова Н.П. К вопросу о местонахождении Апатура / Н.П. Розанова // ВДИ. - 1951. - № 2. C. 210-213.

Ростовцев М.И. Античная декоративная живопись на юге России / М.И. Ростовцев. - СПб., 1914. - T. I: Описание и исследование памятников. - VIII+537 c.

Ростовцев М.И. Скифия и Боспор. Критическое обозрение памятников литературных и археологических / М.И. Ростовцев. - Л., 1925. - 621 с.

Рудольф В. Большая пектораль из Толстой Могилы: работа «чертомлыцкого мастера» и его школы / В. Рудольф // АВ. - 1993. - Вып. 2. - С. 85-90.

Русясва М.В. Діонісійські сюжети на пам'ятках торевтики із скіфських курганів / М.В. Русясва // Археологія. - 1995. - № 1. - С. 22-34.

Русясва М. Образотворче і вжиткове мистецтво / М. Русяєва // Історія українського мистецтва: у 5 т. / голов. ред. Г. Скрипник. - К.: ІМФЕ ім. М.Т. Рильського НАН України, 2008. - Т. 1: Мистецтво первісної доби та стародавнього світу. - С. 380-565.

Рябова В.А. Женское погребение из кургана Денисова Могила / В.А. Рябова // Памятники древних культур Северного Причерноморья. - К.: Наукова думка, 1979. - С. 47-51.

Савостина Е.А. Греческая торевтика на скифские темы: заметки о стиле скульптурного декора

/ Е.А. Савостина // БФ: греческая культура на периферии античного мира: Материалы международной научной конференции. - СПб., 1999. - С. 199-204.

Скрипник Т.А. Головной убор скифянки из Елизаветовского курганного могильника / Т.А. Скрипник // ДА. - 1999. - № 2. - С. 76-84.

Скорый С.А. Большой Рыжановский курган / С.А. Скорый, Я. Хохоровски. - К.: Издатель Олег Филюк, 2018. - 432 с. 
Соколов Г. Терракоты кургана Большая Близница / Г. Соколов // ВИ. - 1997. - № 2 (ХІ). C. $400-420$.

Соколов Г.И. Искусство Боспорского царства / Г.И. Соколов. - М.: Изд-во МЭИ, 1999. - 532 с.

Степанов М.В. Скифский хтонический миф и его отражение в погребальном обряде /

М.В. Степанов. - К.: Издатель Олег Филюк, 2015. - 178 с.

Стефани Л.Э. Объяснение некоторых ваз Императорского Эрмитажа / Л.Э. Стефани // ОАК за 1862 г. - СПб., 1863. - С. 29-170.

Стефани Л.Э. Объяснение некоторых древностей, найденных в 1864 г. в Южной России / Л.Э. Стефани // ОАК за 1865 г. - СПб., 1866. - С. 3-231.

Стефани Л.Э. Объяснение некоторых древностей, найденных в 1868 г. в Южной России / Л.Э. Стефани // ОАК за 1869 г. - СПб., 1871. - С. 3-216.

Строганов С.А. Доклад о действиях Императорской археологической комиссии / С.А. Строганов // ОАК за 1868 г. - СПб., 1869. - С. I-XXII.

Судник Т.М. Мак в растительном коде основного мифа (Balto-Balcanica) / Т.М. Судник, Т.В. Цивьян // Балто-славянские исследования 1980. - М.: Наука, 1981. - С. 300-317.

Тереножкин А.И. Мелитопольский курган / А.И. Тереножкин, Б.Н. Мозолевский. - К.: Наукова думка, 1988. - 260 с.

Толстой И.И. Русские древности в памятниках искусства / И.И. Толстой, Н.П. Кондаков. СПб., 1889. - Вып. 1: Классическия древности Южной России. - 120 с.

Толстой И.И. Русские древности в памятниках искусства / И.И. Толстой, Н.П. Кондаков. СПб., 1889. - Вып. 2. Древности скифо-сарматские. - 162 с.

Топоров В.Н. Мифология: Статьи для мифологических энциклопедий / В.Н. Топоров / предисл. Вяч.Вс. Иванова; ред.-сост. А. Григорян. - М.: Языки славянских культур, 2011. - Т. 1: А-О. - 600 с.

Трейстер М.Ю. Об изделиях торевтики и из скифского кургана Бабина Могила / М.Ю. Трейстер // Мозолевский Б.Н., Полин С.В. Курганы скифского Герроса IV в. до н.э. (Бабина, Водяна и Соболева могилы). - К.: Стилос, 2005. - С. 503-512.

Трейстер М.Ю. Ювелирное дело и торевтика / М.Ю. Трейстер // Античное наследие Кубани: в 3-х т. - М.: Наука, 2010. - Т. 2. - С. 534-597.

Уильямс Д. Греческое золото. Ювелирное искусство классической эпохи V-IV века до н.э. / Д. Уильямс, Д. Огден. - СПб.: Славия, 1995. - 272 с.

Фиалко Е.Е. Скифская Аргимпаса (к интерпретации изображения на ажурной пластине из Гюновки) / Е.Е. Фиалко // БИ. - 2004. - Вып. VII. - С. 47-62.

Фиалко Е.E. 2011. Золотой калаф из кургана Большая Близница: к интерпретации персонажей / Е.Е. Фиалко // Музейні читання. Матеріали наукової конференції «Ювелірне мистецтво - погляд крізь віки». 15-17 листопада 2010 р. - К., 2011. - С. 89-96.

Хамула Д.В. Дионис в Северном Причерноморье: искусство и культ / Д.В. Хамула. - Одесса: Печатный Дом, 2013. - 864 с.

Ходза Е.Н. Гротеск в эллинистической коропластике / Е.Н. Ходза // ВДИ. - 2006. - № 3. C. 156-182.

Ходза Е.Н. Античные терракоты из собрания П.А. Сабурова / Е.Н. Ходза. - СПб.: Изд-во Гос. Эрмитажа, 2018. - 368 c.

Цветаева Г.А. Сокровища причерноморских курганов / Г.А. Цветаева. - М.: Наука, 1968. - 126 с.

Шауб И.Ю. Погребения кургана Большая Близница как источник по истории религиозных представлений жителей Боспорского царства / И.Ю. Шауб // КСИА. - 1987. - № 191. - С. 27-33.

Шауб И.Ю. Из истории языческих верований в Северном Причерноморье: культ фарна у скифов / И.Ю. Шауб // Вестник Православного Свято-Тихоновского Богословского Института. - М.: Изд-во ПСТБИ, 2004. - № 2. - С. 150-159.

Шауб И.Ю. Миф, культ, ритуал в Северном Причерноморье (VII-IV вв. до н. э.) / И.Ю. Шауб. СПб.: Изд-во Санкт-Петербург. ун-та, 2007. - 484 с.

Шауб И.Ю. «Про неправду всё написано!» (О попытках ревизии традиционных взглядов на некоторые памятники Боспора и Скифии). И.Ю. Шауб // БИ. - 2015. - Вып. ХХХІ. - С. 214-222.

Шелов Д.Б. Монетное дело Боспора VI-II вв. до нашей эры / Д.Б. Шелов. - М.: Изд-во АН СССР, 1956. - 220 с. +ІІХ табл.

Черняков I. Технологічні та художні особливості пекторалі з Товстої Могили / I. Черняков, О. Підвисоцька // Музей на рубежі епох: минуле, сьогодення, перспективи (матеріали науковопрактичної конференції). - К., 1999. - С. 77-78. 
Alexandresku P. Les symbolisme funeraire dans une tombe de la peninsula de Taman / P. Alexandresku // Studia Classica. - Bucaresti, 1966. - Vol. 8. - P. 75-86.

Andronikos M. Vergina: the royal tombs and the ancient city / M. Andronikos. - Athenon: Ekdotike Athenon, 1984. $-244 \mathrm{p}$.

Archibald Z.H. The Gold Pectoral from Vergina and its Connections / Z.H. Archibald // Oxford Journal of Archaeology. - 1985. - № 4. - P. 165-185.

Brentjes B. Das Pektorale aus der Tolstaja Mogila und altkleinasiatische Beziehungen / B. Brentjes // Altorientalische Forschungen. - 1994. - Bd. 21. H. 1. - S. 176-180.

Firsov K. Kul'-Oba, Kozel und Aksjutentsy: Fürstengräber zwischen Krim und Waldsteppe / K. Firsov, D. Žuravlev // Im Zeichen des goldenen Greifen. Königsgräber der Skythen / Katalog zur Ausstellung. - München-Berlin: Prestel, 2007. - S. 276-290.

Fornasier J. Das Pektorale aus der Tolstaja Mogila Vergleichende Untersuchungen zur Form und Funktion / J. Fornasier // Zur graeco-skythischen Kunst. Archlologisches Kolloquium Münster. - Münster: Ugarit-Verlag, 1997. - S. 119-146.

Gebauer J. Rankengedanken - zum Pektorale aus der Tolstaja Mogila / J. Gebauer // Zur graecoskythischen Kunst. Archäologisches Kolloquium Münster. 24.-26. November 1995. - Münster: UgaritVerlag, 1997. - S. 147-160.

Jacobson E. The Art of the Scythians: the interpenetration of cultures at the edge of the Hellenic world / E. Jacobson // Handbook of Oriental Studies. - Vol. 2. - Leiden-New York: E.J. Brill, 1995. XVIII+305 p.

Kemeczei T. Studien zu den Denkmälern Skythisch geprägter Alföld Gruppe/ T. Kemeczei. Budapest: Magyar Nemzeti Muzeum, 2009. - 410 S.

Leskov A.M. Die skythischen Kurgane / A.M. Leskov // Antike Welt. - 1974. - Sondernummer. - 100 S.

Minss E.H. Scythians and Greeks / E.H. Minss. - Cambridge: University Press, 1913. - 720 p.

Nawroth M. Der Goldfund von Vettersfelde: Vom Schwarzen Meer in die Lausitz / M. Nawroth // Im Zeichen des goldenen Greifen. Königsgräber der Skythen / Katalog zur Ausstellung. - München-Berlin: Prestel, 2007. - S. 318-327.

Piotrovsky B. La découverte de la civilisation scythe. Histoire des fouilles / B. Piotrovsky // Or des Scythes. Trésors des musées soviétiques. - Paris: Edité par Musées nationaux, 1975. - P. 11-24.

Piotrovsky B. Scythian Art. The legacy of the Scythian world: mid- $7^{\text {th }}$ to $3^{\text {rd }}$ century B.C. / B. Piotrovsky, L. Galanina, N. Grach. - Leningrad: Aurora, 1986. - 184 p.

Pfrommer M. Grossgriechischer und mittelitalischer Einfluss in der Rankenornamentik frühhellenistischer Zeit / M. Pfrommer // Jahrbuch des Deutschen Archaeologischen Instituts. - 1982. Bd. 97. - S. 119-190.

Pfrommer M. Untersuchungen zur Chronologie früh- und hochhellenistischen Goldschmucks / M. Pfrommer. - Tübingen: Wasmuth, 1990. - $470 \mathrm{~S}$.

Schiltz V. Die Skythen und andere Steppenvölker. 8. Jahrhundert v. Chr. bis 1. Jahrhundert n. Chr. / V. Schiltz. - München: Verlag C.H. Beck, 1994. - XVI+473 S.

Schwarzmaier A. Die Gräber in der Großen Blisniza und ihre Datierung / A. Schwarzmaier // Jahrbuch des Deutschen Archäologischen Instituts. - 1996. - Bd. 111. - S. 105-137.

Schwarzmaier A. «Ich werde immer Kore heißen» - zur Grabstele der Polyxena in der Berliner Antikesammlung. Mit einem Anhang zu den Schmuckgarnituren aus der Großen Blisniza auf der Halbinsel Taman / A. Schwarzmaier // Jahrbuch des Deutschen Archäologischen Instituts. - 2006. - Bd. 121. - S. 175-226.

Scythian gold. Treasures from ancient Ukraine / Ed. E. Reeder. - New York: Abrams Inc. Publishers, 1999. - P. 326-331. - 352 p.

Themelis P. Macedonian dedications on the Akropolis / P. Themelis // The Macedonians in Athens, 322-229 BC. - Oxford: Oxbow, 2003. - P. 162-172.

Treister M. Masters and Workshops of the Jewellery and Toreutics from Fourth-Century Scythian Burial-Mounds / M. Treister // Scythians and Greeks. Cultural Interactions in Scythia, Athens and the Early Roman Empire (sixth century BC - first century AD). - Exeter: University of Exeter Press, 2005. - P. 56-63, 190-194.

Vickers M. Scythian and Thracian Antiquities in Oxford / M. Vickers. - Oxford: Ashmolean Museum, 2002. -80 p.

Williams D. Identifying Greek Jewelers and Goldsmiths / D. Williams // The Art of the Greek Goldsmith. - London: British Museum Press, 1998. - P. 99-104.

Züchner W. Griechische Klappspiegel / W. Züchner. - Berlin: Walter de Gruyter, 1942. VIII+238 S. 


\section{REFERENCES}

Alekseev A.Iu. Zametki po khronologii skifskikh stepnykh drevnostei IV v. do n.e. / A.Iu. Alekseev // SA. - 1987. - № 3. - S. 28-39.

Alekseev A.Iu. Khronografiia Evropeiskoi Skifii VII-IV vekov do n.e. / A.Iu. Alekseev. - SPb.: Izdvo Gos. Ermitazha, 2003. - 416 s.

Alekseev A.Iu. Zoloto skifskikh tsarei iz sobraniia Ermitazha / A.Iu. Alekseev. - SPb.: Izd-vo Gos. Ermitazha, 2012. - $272 \mathrm{~s}$.

Alekseev A.Iu. Chertomlyk. Skifskii tsarskii kurgan IV v. do n.e. / [A.Iu. Alekseev, V.Iu. Murzin, R. Rolle]. - K.: Naukova dumka, 1991. - 413 s.

Artamonov M.I. Sokrovishcha skifskikh kurganov v sobranii Gosudarstvennogo Ermitazha / M.I. Artamonov. - Praga: Artiia; L.: Sovetskii khudozhnik, 1966. -120 s. +331 tabl.

Babenko L.I. Pesochinskii kurgannyi mogilnik skifskogo vremeni / L.I. Babenko. - Kharkov: ID Raider, 2005. - $284 \mathrm{~s}$.

Babenko L.I. Pan i siuzhet pektorali - nesluchainye sovpadeniia? / L.I. Babenko // ADIU. - 2016. Vyp. 2 (19). - S. 9-26.

Babenko L.I. Dva monetnykh siuzheta na izdeliiakh greko-skifskoi torevtiki / L.I. Babenko // ADIU. - 2017. - Vyp. 2 (23). - S. 30-39.

Babenko L.I. Sharnirnye petli pektorali iz Tolstoi Mogily / L.I. Babenko // Muzeini chytannia. Materialy naukovoi konferentsii «Iuvelirne mystetstvo - pohliad kriz viky». - Kyiv, Muzei istorychnykh koshtovnostei Ukrainy, 21-22 lystopada 2016 r. - K.: TOV «Feniks», 2017a. - S. 37-47.

Babenko L.I. Konstruktsiia i tekhnika izgotovleniia zhguta grivny iz Kul-Oby / L.I. Babenko // Muzeini chytannia. Materialy naukovoi konferentsii «Iuvelirne mystetstvo - pohliad kriz viky». - Kyiv, Muzei istorychnykh koshtovnostei Ukrainy, 21-22 lystopada 2017 r. - K.: TOV «Feniks», 2018. - S. 30-47.

Babenko L.I. O bordiurakh pektoralei iz Tolstoi Mogily i Bolshoi Bliznitsy / L.I. Babenko // ADIU. 2018a. - Vyp. 2 (27). - S. 155-163.

Babenko L.I. Pektoral ili grivna? (o sootvetstvii termina i morfologii ukrasheniia) / L.I. Babenko // Stratum plus. -2018 b. - № 3. - S. 187-204.

Babenko L.I. Vitye i lozhnovitye sheinye ukrasheniia iz masterskikh bosporskikh torevtov / L.I. Babenko // ADIU. - 2019. - Vyp. 2 (31). - S. 493-505.

Babenko L.I. Zhinochyi holovnyi ubir IV st. do n.e. z kurhanu 8 bilia s. Pisochyn Kharkivskoi oblasti / L.I. Babenko // Arkheolohiia. - 2002. - № 4. - S. 59-69.

Babenko L.I. Do semantyky tsentralnoi stseny pektorali z Tovstoi Mohyly / L.I. Babenko // Drevnosti 2013: Kharkovskii istoriko-arkheologicheskii ezhegodnik. - Kharkov: Kharkovskoe istorikoarkheologicheskoe obshchestvo; OOO «NTMT», 2013. - S. 111-122.

Bessonova S.S. Religioznye predstavleniia skifov / S.S. Bessonova. - K.: Naukova dumka, 1983. - $138 \mathrm{~s}$.

Bidzilia V.I. Skifskii tsarskii kurgan Gaimanova Mogila / V.I. Bidzilia, S.V. Polin. - K.: Izdatelskii dom «Skif», 2012. - $752 \mathrm{~s}$.

Boltrik Iu.V. Sotsialnaia struktura Skifii IV v. do R.Kh., otrazhennaia v pogrebalnykh pam'iatnikakh // Kimmerowe, Scytowie, Sarmaci. Księga poświęcona pamięci profesora Tadeusza Sulimirskego. Krakow: Księgarnia Akademicka, 2004. - S. 85-91.

Boltrik Iu.V. Ukrasheniia iz skifskikh pogrebalnykh kompleksov Rogachikskogo kurgannogo polia / Iu.V. Boltrik, E.E. Fialko // SSPK. - 2007. - T. XIV. - S. 51-93.

Boltryk Yu.V. Importnyi bronzovyi posud iz skhidnoi mohyly Berdianskoho kurhanu / [Yu.V. Boltryk, M.Yu. Treister, O.Ye. Fialko] // Arkheolohiia. - 2009. - № 1. - S. 40-52.

Venedikov I. Trakiyskoto izkustvo / I. Venedikov, T. Gerasimov. - Sofia: Bylgarski hudozhnik, 1973. $-408 \mathrm{~s}$.

Vertiienko H.V. Ikonohrafiia skifskoi eskhatolohii / H.V. Vertiienko. - K.: Instytut skhodoznavstva im.A.Yu. Krymskoho NAN Ukrainy, Vydavets Oleh Filiuk, 2015. - 224 s.

Gavriliuk N.A. Istoriia ekonomiki Stepnoi Skifii VI-III vv. do n.e. / N.A. Gavriliuk. - K.: Izd-vo PTF, 1999. - 424 s.

Gavriliuk N.A. Pektoral iz Tolstoi Mogily kak istochnik dlia izucheniia ekonomiki Stepnoi Skifii. Istoriografiia voprosa / N.A. Gavriliuk // ADIU. - 2016. - Vyp. 2 (19). - S. 284-291.

Gavriliuk N.A. Pektoral iz Tolstoi Mogily kak obieekt i sredstvo neverbalnoi kommunikatsii / N.A. Gavriliuk, N.P. Timchenko // TGE. - 2015. - [T.] LXXVII: Arkheologiia bez granits: kollektsii, problemy, issledovaniia, gipotezy. - S. 97-126. 
Gaidukevich V.F. Bosporskoe tsarstvo / V.F. Gaidukevich. - M.-L.: Izd-vo AN SSSR, 1949. - 624 s.

Grach N.L. Terrakotovye statuetki iz kurgana Bolshaia Bliznitsa / N.L. Grach // SAI. - M.: Nauka, 1974. - Vyp. G1-11. Ch. IV. Terrakotovye statuetki. Pridone i Tamanskii poluostrov. - S. 36-39.

Grebnev Ia.V. K voprosu ob istorii otechestvennogo kozovodstva / Ia.V. Grebnev // Kniaz S.P. Urusov. Kniga o koze / redakt. i sovr. komment. Ia.V. Grebneva. - K.: NNTs Institut agrarnoi ekonomiki, 2007. - S. 288-304.

Grebennikov Iu. Istoriia naseleniia Stepnogo Pobuzhia v VI-V st. do n.e. / Iu. Grebennikov, L. Smirnov // Forum Olbicum II. Pam'iati V.V. Krapivinoi (do 150-richchia doslidzhennia Olvii). Materialy mizhnarodnoi arkheolohichnoi konferentsii (4-6 travnia 2018 r.). - Mykolaiv: Lukomor'ie, 2018. - S. 120-121.

Drevnosti Bospora Kimmeriiskogo, khraniashchiesia v imperatorskom muzee Ermitazha. - SPb., 1854. - T. I. - CLIV+279 s.

Kalashnik Iu.P. Grecheskoe zoloto v sobranii Ermitazha: Pamiatniki antichnogo iuvelirnogo iskusstva iz Severnogo Prichernomoria / Iu.P. Kalashnik. - SPb.: Izd-vo Gos. Ermitazha, 2014. - 280 s.

Korolkova E.F. Ikonografiia obraza khishchnoi ptitsy v skifskom zverinom stile VI-IV vv. do n.e. / E.F. Korolkova // Problemy arkheologii. - SPb., 1998. - Vyp. 4. - S. 166-177.

Kruglov A.V. Rekonstruktsiia ellinisticheskoi skulpturnoi gruppy «Rozhdenie Dionisa iz bedra Zevsa»/ A.V. Kruglov // Ellinisticheskie shtudii v Ermitazhe. K shestidesiatiletiiu Mikhaila Borisovicha Piotrovskogo. - SPb.: Izd-vo Gos. Ermitazha, 2004. - S. 34-43.

Kuzmina E.E. Opyt interpretatsii nekotorykh pamiatnikov skifskogo iskusstva / E.E. Kuzmina // VDI. - 1984. - № 1. - S. 93-108.

Kuzmina E.E. Siuzhet borby khishchnika i kopytnogo v iskusstve «zverinogo» stilia evraziiskikh stepei skifskoi epokhi / E.E. Kuzmina // Skifo-sibirskii mir. Iskusstvo i ideologiia. - Novosibirsk: Nauka, 1987. - S. 3-12.

Kuprii S.O. Kurhan 6 mohylnyka Vodoslavka: pokhovannia skifskoi znati / [S.O. Kuprii, O.V. Lifantii, O.V. Shelekhan] // ADIU. - 2019. - Vyp. 4 (33). - S. 182-212.

Kuchma L.D. Ukraina - ne Rossiia / L.D. Kuchma. - M.: Vremia, 2003. - 560 s.

Mantsevich A.P. K voprosu o torevtike v skifskuiu epokhu / A.P. Mantsevich // VDI. - 1949. - № 2. - S. 196-220.

Mantsevich A.P. Chertomlykskaia vaza i pektoral iz Tolstoi Mogily / A.P. Mantsevich // Pulpudeva. - Sofia, 1974. - Vol. I. - S. 83-98.

Mantsevich A.P. Zolotoi nagrudnik iz Tolstoi Mogily / A.P. Mantsevich // Thracia Serdicae. - 1980. - Vol. V. - S. 97-120.

Mantsevich A.P. Kurgan Solokha. Publikatsiia odnoi kollektsii / A.P. Mantsevich. - L.: Iskusstvo, 1987. - $143 \mathrm{~s}$.

Machinskii D.A. Pektoral iz Tolstoi Mogily i velikie zhenskie bozhestva Skifii / D.A. Machinskii // Kultura Vostoka: Drevnost i rannee srednevekove. - L.: Avrora, 1978. - S. 131-150.

Mikhailin V. Tropa zverinykh slov: Prostranstvenno-orientirovannye kulturnye kody V indoevropeiskoi traditsii / V. Mikhailin. - M.: Novoe literaturnoe obozrenie, 2005. - $528 \mathrm{~s}$.

Mozolevskii B.N. Kurgan Tolstaia Mogila bliz g. Ordzhonikidze na Ukraine / B.N. Mozolevskii // SA. - 1972. - № 3. - S. 268-308.

Mozolevskii B.N. Skifskie kurgany v okrestnostiakh g. Ordzhonikidze na Dnepropetrovshchine (raskopki 1972-1975 gg.) / B.N. Mozolevskii // Skifiia i Kavkaz. - K.: Naukova dumka, 1980. - S. 70-154.

Mozolevskii B.N. Kurgany skifskogo Gerrosa IV v. do n.e. (Babina, Vodiana i Soboleva mogily) /

B.N. Mozolevskii, S.V. Polin. - K.: Izdatelskii dom «Stilos», 2005. - 600 s. +24 tabl. tsv.ill.

Mozolevskyi B. Syntez skifo-antychnoi dumky. Do interpretatsii pektorali z Tovstoi Mohyly / B. Mozolevskyi // Vsesvit. - 1978. - № 2. - S. 191-204.

Mozolevskyi B.M. Tovsta Mohyla / B.M. Mozolevskyi. - K.: Naukova dumka, 1979. - 251 s.

Moleva N.V. Tandem «zaiats - sobaka» v religioznom mirovozzrenii drevnikh grekov / N.V. Moleva // Artefakty i sakralnoe v istorii Bospora. - Nizhnii Novgorod: Izd-vo NNGU, 2017. - S. 79-91.

Moshinskii A.P. Pektoral iz Tolstoi Mogily kak simvol tsarskoi vlasti / A.P. Moshinskii // DA. 2002. - № 1-2. - S. 84-88.

Murzin V.Iu. Berdianskii kurgan (pogrebalnyi kompleks skifskogo aristokrata IV v. do n.e.) /

[V.Iu. Murzin, Iu.A. Belan, E.P. Podvysotskaia]. - K.: Vidavets Oleg Filiuk, 2017. - 136 s.

Nikolskaia K.D. O strannom nasledstve v III knige «Artkhashastry» Kautili / K.D. Nikolskaia // Stratum plus. - 2005-2009. - № 3. Skifskie interpretatsii. - S. 371-376.

OAK za 1869 god: s atlasom. - SPb., 1871. - XXII+256 s.+VI tabl. 
Onaiko N.A. Antichnyi import v Pridnestorove i Pobuzhe v IV-II vv. do n.e. / N.A. Onaiko // SAI. 1970. - Vyp. D1-27. - 212 s.

Peredolskaia A.A. O siuzhetakh trekh terrakotovykh statuetok, naidennykh v kurgane Bolshaia Bliznitsa / A.A. Peredolskaia / SA. - 1950. - T. XIII. - S. 255-271.

Peredolskaia A.A. K voprosu o terrakotakh iz kurgana Bolshaia Bliznitsa / A.A. Peredolskaia // SA. 1955. - T. XXIV. - S. 54-73.

Peredolskaia A.A. Terrakoty iz kurgana Bolshaia Bliznitsa i Gomerovskii gimn Demetre / A.A. Peredolskaia / TGE. - 1962 - T. VII. - S. 46-93.

Petrenko V.G. Ukrasheniia Skifii VII-III vv. do n.e. / V.G. Petrenko // SAI. - M.: Nauka, 1978. Vyp. D4-5. - 144 s.

Petrukhin V.Ia. «Zolotoe runo» i «skifskaia kosmogramma» / V.Ia. Petrukhin // MIF-7: Apotéosis. Na akad. Dmitri Sergeevich Raevski. - Sofiia, 2001. - S. 147-156.

Pidvysotska O.P. Tekhnolohichni sposterezhennia nad serednim yarusom pektorali iz Tovstoi Mohyly / O.P. Pidvysotska, I.T. Cherniakov // Muzeini chytannia. Materialy naukovoi konferentsii. Hruden 2001 r. - K.: Muzei istorychnykh koshtovnostei Ukrainy, 2002. - S. 17-26.

Polidovich Iu.B. Pektoral - simvol zhizni i smerti / Iu.B. Polidovich // Zhurnal o metalle. - 2006. № 3-4 (9). - S. 82-85.

Polidovich Iu.B. Bosporskie terrakotovye statuetki so stsenoi okhoty na zaitsa / Iu.B. Polidovich // BF: sakralnyi smysl regiona, pamiatnikov, nakhodok. Materialy Mezhdunarodnoi nauchnoi konferentsii. Chast I. - SPb., 2007. - S. 93-99.

Polidovich Iu.B. Obraz zaitsa v skifskom iskusstve / Iu.B. Polidovich, G.N. Volnaia // Drevnosti Evrazii ot rannei bronzy do rannego srednevekovia. Pamiati V.S. Olkhovskogo. - M.: IA RAN, 2005. S. 425-436.

Polin S.V. Skifskii Zolotobalkovskii kurgannyi mogilnik V-IV vv. do n.e. na Khersonshchine / S.V. Polin. - K.: Izdatel Oleg Filiuk, 2014. - 776 s.

Pruglo V.I. K voprosu o date kurgana Bolshaia Bliznitsa / V.I. Pruglo // SA. - 1974. - № 3. - S. 64-77.

Raevskii D.S. Iz oblasti skifskoi kosmologii (Opyt semanticheskoi interpretatsii pektorali iz Tolstoi Mogily) / D.S. Raevskii // VDI. - 1978. - № 3. - S. 115-133.

Raevskii D.S. Model mira skifskoi kultury. Problemy mirovozzreniia iranoiazychnykh narodov evraziiskikh stepei I tysiacheletiia do n.e. / D.S. Raevskii. - M.: Nauka, 1985. - 256 s.

Rozanova N.P. K voprosu o mestonakhozhdenii Apatura / N.P. Rozanova // VDI. - 1951. - № 2. S. 210-213.

Rostovtsev M.I. Antichnaia dekorativnaia zhivopis na iuge Rossii / M.I. Rostovtsev. - SPb., 1914. T. I: Opisanie i issledovanie pamiatnikov. - VIII+537 s.

Rostovtsev M.I. Skifiia i Bospor. Kriticheskoe obozrenie pamiatnikov literaturnykh i arkheologicheskikh / M.I. Rostovtsev. - L., 1925. - 621 s.

Rudolf V. Bolshaia pektoral iz Tolstoi Mogily: rabota «chertomlytskogo mastera» i ego shkol / V. Rudolf // AV. - 1993. - Vyp. 2. - S. 85-90.

Rusiaieva M.V. Dionisiiski siuzhety na pam'iatkakh torevtyky iz skifskykh kurhaniv / M.V. Rusiaieva // Arkheolohiia. - 1995. - № 1. - S. 22-34.

Rusiaieva M. Obrazotvorche i vzhytkove mystetstvo/ M. Rusiaieva // Istoriia ukrainskoho mystetstva: u 5 t. / holov. red. H. Skrypnyk. - K.: IMFE im. M.T. Rylskoho NAN Ukrainy, 2008. - T. 1: Mystetstvo pervisnoi doby ta starodavnoho svitu. - S. 380-565.

Riabova V.A. Zhenskoe pogrebenie iz kurgana Denisova Mogila / V.A. Riabova // Pamiatniki drevnikh kultur Severnogo Prichernomoria. - K.: Naukova dumka, 1979. - S. 47-51.

Savostina E.A. Grecheskaia torevtika na skifskie temy: zametki o stile skulpturnogo dekora / E.A. Savostina // BF: grecheskaia kultura na periferii antichnogo mira. Materialy mezhdunarodnoi nauchnoi konferentsii. - SPb., 1999. - S. 199-204.

Skripnik T.A. Golovnoi ubor skifianki iz Elizavetovskogo kurgannogo mogilnika / T.A. Skripnik // DA. - 1999. - № 2. - S. 76-84.

Skoryi S.A. Bolshoi Ryzhanovskii kurgan / S.A. Skoryi, Ia. Khokhorovski. - K.: Izdatel Oleg Filiuk, 2018. - $432 \mathrm{~s}$.

Sokolov G. Terrakoty kurgana Bolshaia Bliznitsa / G. Sokolov // VI. - 1997. - № 2 (XI). - S. 400-420.

Sokolov G.I. Iskusstvo Bosporskogo tsarstva / G.I. Sokolov. - M.: Izd-vo MEI, 1999. - 532 s.

Stepanov M.V. Skifskii khtonicheskii mif i ego otrazhenie v pogrebalnom obriade / M.V. Stepanov. K.: Izdatel Oleg Filiuk, 2015. - 178 s. 
Stefani L.E. Obieiasnenie nekotorykh vaz Imperatorskogo Ermitazha / L.E. Stefani // OAK za $1862 \mathrm{~g}$. - SPb., 1863. - S. 29-170.

Stefani L.E. Obieiasnenie nekotorykh drevnostei, naidennykh v 1864 g. v Iuzhnoi Rossii /

L.E. Stefani // OAK za 1865 g. - SPb., 1866. - S. 3-231.

Stefani L.E. Obieiasnenie nekotorykh drevnostei, naidennykh v 1868 g. V Iuzhnoi Rossii /

L.E. Stefani // OAK za 1869 g. - SPb., 1871. - S. 3-216.

Stroganov S.A. Doklad o deistviiakh Imperatorskoi arkheologicheskoi komissii / S.A. Stroganov // OAK za 1868 g. - SPb., 1869. - S. I-XXII.

Sudnik T.M. Mak v rastitelnom kode osnovnogo mifa (Balto-Balcanica) / T.M. Sudnik, T.V. Tsivian // Balto-slavianskie issledovaniia 1980. - M.: Nauka, 1981. - S. 300-317.

Terenozhkin A.I. Melitopolskii kurgan / A.I. Terenozhkin, B.N. Mozolevskii. - K.: Naukova dumka, 1988. - $260 \mathrm{~s}$.

Tolstoi I.I. Russkie drevnosti v pamiatnikakh iskusstva / I.I. Tolstoi, N.P. Kondakov. - SPb., 1889. Vyp. 1: Klassicheskiia drevnosti Iuzhnoi Rossii. - 120 s.

Tolstoi I.I. Russkie drevnosti v pamiatnikakh iskusstva / I.I. Tolstoi, N.P. Kondakov. - SPb., 1889. Vyp. 2: Drevnosti skifo-sarmatskie. - $162 \mathrm{~s}$.

Toporov V.H. Mifologiia: Stati dlia mifologicheskikh entsiklopedii / V.H. Toporov / predisl. Viach.Vs. Ivanova; red.-sost. A. Grigorian. - M.: Iazyki slavianskikh kultur, 2011. - T. 1: A-O. - 600 s.

Treister M.Iu. Ob izdeliiakh torevtiki i iz skifskogo kurgana Babina Mogila / M.Iu. Treister // Mozolevskii B.N., Polin S.V. Kurgany skifskogo Gerrosa IV v. do n.e. (Babina, Vodiana i Soboleva mogily). - K.: Stilos, 2005. - S. 503-512.

Treister M.Iu. Iuvelirnoe delo i torevtika / M.Iu. Treister // Antichnoe nasledie Kubani: v 3-kh tomakh. - M.: Nauka, 2010. - T. 2. - S. 534-597.

Uiliams D. Grecheskoe zoloto. Iuvelirnoe iskusstvo klassicheskoi epokhi V-IV veka do n.e. / D. Uiliams, D. Ogden. - SPb.: Slaviia, 1995. - 272 s.

Fialko E.E. Skifskaia Argimpasa (k interpretatsii izobrazheniia na azhurnoi plastine iz Giunovki) / E.E. Fialko // BI. - 2004. - Vyp. VII. - S. 47-62.

Fialko E.E. 2011. Zolotoi kalaf iz kurgana Bolshaia Bliznitsa: k interpretatsii personazhei / E.E. Fialko // Muzeini chytannia. Materialy naukovoi konferentsii «Iuvelirne mystetstvo - pohliad kriz viky». 15-17 lystopada 2010 r. - K., 2011. - S. 89-96.

Khamula D.V. Dionis v Severnom Prichernomore: iskusstvo i kult / D.V. Khamula. - Odessa: Pechatnyi Dom, 2013. - 864 s.

Khodza E.N. Grotesk v ellinisticheskoi koroplastike / E.N. Khodza // VDI. - 2006. - № 3. - S. 156-182.

Khodza E.N. Antichnye terrakoty iz sobraniia P.A. Saburova / E.N. Khodza. - SPb.: Izd-vo Gos. Ermitazha, 2018. - $368 \mathrm{~s}$.

Tsvetaeva G.A. Sokrovishcha prichernomorskikh kurganov/ G.A. Tsvetaeva. - M.: Nauka, 1968. - $126 \mathrm{~s}$.

Shaub I.Iu. Pogrebeniia kurgana Bolshaia Bliznitsa kak istochnik po istorii religioznykh predstavlenii zhitelei Bosporskogo tsarstva / I.Iu. Shaub // KSIA. - 1987. - № 191. - S. 27-33.

Shaub I.Iu. Iz istorii iazycheskikh verovanii v Severnom Prichernomore: kult farna u skifov / I.Iu. Shaub // Vestnik Pravoslavnogo Sviato-Tikhonovskogo Bogoslovskogo Instituta. - M.: Izd-vo PSTBI, 2004. - № 2. - S. 150-159.

Shaub I.Iu. Mif, kult, ritual v Severnom Prichernomore (VII-IV vv. do n. e.) / I.Iu. Shaub. - SPb.: Izd-vo Sankt-Peterburg. un-ta, 2007. - $484 \mathrm{~s}$.

Shaub I.Iu. «Pro nepravdu vse napisano!» (O popytkakh revizii traditsionnykh vzgliadov na nekotorye pamiatniki Bospora i Skifii) / I.Iu. Shaub // BI. - 2015. - Vyp. XXXI. - S. 214-222.

Shelov D.B. Monetnoe delo Bospora VI-II vv. do nashei ery / D.B. Shelov. - M.: Izd-vo AN SSSR, 1956. -220 s. +IX tabl.

Cherniakov I. Tekhnolohichni ta khudozhni osoblyvosti pektorali z Tovstoi Mohyly / I. Cherniakov, O. Pidvysotska // Muzei na rubezhi epokh: mynule, sohodennia, perspektyvy (materialy naukovopraktychnoi konferentsii). - K., 1999. - S. 77-78.

Alexandresku P. Les symbolisme funeraire dans une tombe de la peninsula de Taman / P. Alexandresku // Studia Classica. - Bucaresti, 1966. - Vol. 8. - P. 75-86.

Andronikos M. Vergina: the royal tombs and the ancient city / M. Andronikos. - Athenon: Ekdotike Athenon, 1984. $-244 \mathrm{p}$.

Archibald Z.H. The Gold Pectoral from Vergina and its Connections / Z.H. Archibald // Oxford Journal of Archaeology. - 1985. - № 4. - P. 165-185. 
Brentjes B. Das Pektorale aus der Tolstaja Mogila und altkleinasiatische Beziehungen / B. Brentjes // Altorientalische Forschungen. - 1994. - Bd. 21. H. 1. - S. 176-180.

Firsov K. Kul'-Oba, Kozel und Aksjutentsy: Fürstengräber zwischen Krim und Waldsteppe / K. Firsov, D. Žuravlev // Im Zeichen des goldenen Greifen. Königsgräber der Skythen / Katalog zur Ausstellung. - München-Berlin: Prestel, 2007. - S. 276-290.

Fornasier J. Das Pektorale aus der Tolstaja Mogila Vergleichende Untersuchungen zur Form und Funktion / J. Fornasier // Zur graeco-skythischen Kunst. Archlologisches Kolloquium Münster. - Münster: Ugarit-Verlag, 1997. - S. 119-146.

Gebauer J. Rankengedanken - zum Pektorale aus der Tolstaja Mogila / J. Gebauer // Zur graecoskythischen Kunst. Archäologisches Kolloquium Münster. 24.-26. November 1995. - Münster: UgaritVerlag, 1997. - S. 147-160.

Jacobson E. The Art of the Scythians: the interpenetration of cultures at the edge of the Hellenic world / E. Jacobson / Handbook Of Oriental Studies. - Vol. 2. - Leiden-New York: E.J. Brill, 1995. XVIII+305 p.

Kemeczei T. Studien zu den Denkmälern Skythisch geprägter Alföld Gruppe / T. Kemeczei. Budapest: Magyar Nemzeti Muzeum, 2009. - 410 S.

Leskov A.M. Die skythischen Kurgane / A.M. Leskov // Antike Welt. - 1974. - Sondernummer. - 100 S.

Minss E.H. Scythians and Greeks / E.H. Minss. - Cambridge: University Press, 1913. - 720 p.

Nawroth M. Der Goldfund von Vettersfelde: Vom Schwarzen Meer in die Lausitz / M. Nawroth // Im Zeichen des goldenen Greifen. Königsgräber der Skythen / Katalog zur Ausstellung. - München-Berlin: Prestel, 2007. - S. 318-327.

Piotrovsky B. La découverte de la civilisation scythe. Histoire des fouilles / B. Piotrovsky // Or des Scythes. Trésors des musées soviétiques. - Paris: Edité par Musées nationaux, 1975. - P. 11-24.

Piotrovsky B. Scythian Art. The legacy of the Scythian world: mid- $7^{\text {th }}$ to $3^{\text {rd }}$ century B.C. / [B. Piotrovsky, L. Galanina, N. Grach]. - Leningrad: Aurora, 1986. - 184 p.

Pfrommer M. Grossgriechischer und mittelitalischer Einfluss in der Rankenornamentik frühhellenistischer Zeit / M. Pfrommer // Jahrbuch des Deutschen Archaeologischen Instituts. - 1982. Bd. 97. - S. 119-190.

Pfrommer M. Untersuchungen zur Chronologie früh- und hochhellenistischen Goldschmucks / M. Pfrommer. - Tübingen: Wasmuth, 1990. - $470 \mathrm{~S}$.

Schiltz V. Die Skythen und andere Steppenvölker. 8. Jahrhundert v. Chr. bis 1. Jahrhundert n. Chr. / V. Schiltz. - München: Verlag C.H. Beck, 1994. - XVI+473 S.

Schwarzmaier A. Die Gräber in der Großen Blisniza und ihre Datierung / A. Schwarzmaier / Jahrbuch des Deutschen Archäologischen Instituts. - 1996. - Bd. 111. - S. 105-137.

Schwarzmaier A. «Ich werde immer Kore heißen»- zur Grabstele der Polyxena in der Berliner Antikesammlung. Mit einem Anhang zu den Schmuckgarnituren aus der Großen Blisniza auf der Halbinsel Taman / A. Schwarzmaier // Jahrbuch des Deutschen Archäologischen Instituts. - 2006. - Bd. 121. - S. 175-226.

Scythian gold. Treasures from ancient Ukraine / Ed. E. Reeder. - New York: Abrams Inc. Publishers, 1999. - P. 326-331. - 352 p.

Themelis P. Macedonian dedications on the Akropolis / P. Themelis // The Macedonians in Athens, 322-229 BC. - Oxford: Oxbow, 2003. - P. 162-172.

Treister M. Masters and Workshops of the Jewellery and Toreutics from Fourth-Century Scythian Burial-Mounds / M. Treister // Scythians and Greeks. Cultural Interactions in Scythia, Athens and the Early Roman Empire (sixth century BC - first century AD). - Exeter: University of Exeter Press, 2005. - P. 56-63, 190-194.

Vickers M. Scythian and Thracian Antiquities in Oxford / M. Vickers. - Oxford: Ashmolean Museum, 2002. $-80 \mathrm{p}$.

Williams D. Identifying Greek Jewelers and Goldsmiths / D. Williams // The Art of the Greek Goldsmith. - London: British Museum Press, 1998. - P. 99-104. VIII+238 S.

Züchner W. Griechische Klappspiegel / W. Züchner. - Berlin: Walter de Gruyter, 1942. - 